(1) 1 () $\mathrm{y}$ is 1 is

O IMPACTO DOS PRIMELROS SÉCULOS DE HISTÓRIA DA AMÉRICA PORTUGUESA NA FORMAÇÃO DA BRASILIDADE ALIMENTAR




"Mapa do Brasil"

Quadro de Jean-Baptiste Debret (1768-1848).

Disponivel no site:

http://www.pitoresco.com/pitoresco/brasil/debret/debret.htm. 


\section{O IMPACTO DOS PRIMEIROS SÉCULOS DE HISTÓRIA DA AMÉRICA PORTUGUESA NA FORMAÇÃO DA BRASILIDADE ALIMENTAR}

\section{ROSEMEIRE BERTOLINI LORIMER}

Tese de doutorado apresentada ao Departamento de Nutrição da Faculdade de Saúde Pública da Universidade de São Paulo para a obtenção do título de Doutor.

Área de Concentração: Nutrição

Orientadora: Profa. Dra. Midori Ishii

São Paulo

2001 
Autorizo, exclusivamente para fins acadêmicos e científicos, a reprodução total ou parcial desta tese, por processos fotocopiadores.



Data: 03 de Dezembro de 2001. 


\section{$D_{\text {edico este trabalho a todos aqueles }}$}

que ao longo da história tem dedicado suas vidas para fazer do Brasil uma grande nação, tentando dar a esse povo, tão valente e trabalhador, o direito de ser respeitado, através do exercício pleno de sua cidadania, garantindo, acima de tudo, que possam se alimentar e viver de forma saudável. 
Meus sinceros agradecimentos

a Deus, pela saúde e motivação, que por várias vezes estiveram ausentes, mas foram restauradas,

no meu marido, Bruce Lorimer, que nunca me deixou desistir,

ao meu primo Marcos, pela sua incansável disposição,

aos meus pais, que tanto se esforçaram para me dar uma boa educação,

à Profa. Midori Ishii, pela orientação, confiança e incentivo mesmo quando tudo parecia nublado,

à Escola de Nutrição UFBA, que na pessoa das professoras me receberam tão calorosamente para realização de estudos alimentares junto a este estado,

a todos aqueles que gentilmente participaram de alguma forma na elaboração deste trabalho. 


\section{RESUMO}

Lorimer RB. O impacto dos primeiros séculos de história da América portuguesa na formação da brasilidade alimentar. São Paulo; 2001. [Tese de Doutorado - Faculdade de Saúde Pública da USP].

O hábito alimentar de um povo é um fenômeno complexo que se forma a partir da interaçào de fatores que são determinados pelas várias esferas da sociedade. $\mathrm{O}$ uso da História, entre outras áreas do saber, tem ajudado a compreender esse processo.

Para descobrir como isso se deu no caso do Brasil, iniciou-se uma busca em um período anterior ao das grandes navegaçōes, já que os portugueses, principais colonizadores do Brasil, já traziam consigo uma bagagem cultural que foi fundamental para estabelecer na colônia as bases da alimentação. Constatou-se que a necessidade de superar as primeiras dificuldades levaram os colonizadores a adotar hábitos indígenas, mas principalmente seu tipo de lavoura e seus alimentos; a substituiçào dos ingredientes europeus por similares da colônia foi um segundo passo importante; o terceiro elemento a se unir foi o escravo negro, que mais tarde agregaria seus conhecimentos à cozinha das grandes fazendas, resultando em um modo alimentar original, baseado na farinha de mandioca, no milho e seus derivados, no feijão e na carne seca.

Apesar de tudo, a colônia manteve uma alimentação pobre em muitas regiōes devido, entre outras coisas, ao rareamento e encarecimento de produtos vindos de Portugal, insuficiente atividade agrícola de subsistência e deficiência no transporte de alimentos para regiōes mais distantes, além de um aumento vertiginoso da população, principalmente na região das minas. 
Por fim, observou-se que esse quadro alimentar, caracterizado pela penúria, improvisação e criatividade, resultou, entre outras coisas, num cenário endêmico de subnutrição, que ainda pode ser observado em muitas partes do Brasil de hoje, mas que, por outro lado, contribuiu para a formação das típicas e elogiadas cozinhas baiana e mineira, verdadeiras jóias na cultura do país.

Descritores: História da alimentação no Brasil. Alimentação colonial. Hábitos alimentares no Brasil. 


\section{SUMMARY.}

Lorimer RB. O impacto dos primeiros séculos de história da América portuguesa na formação da brasilidade alimentar. [The impact of the first centuries of history of Portuguese domination of the America in Brazilian eating habits]. São Paulo (BR); 2001. [Tese de Doutorado - Faculdade de Saúde Pública da USP].

Alimentary habits of peoples is a complex phenomenon formed by the interaction of factors determined by the various spheres of society. The use of History, among other knowledge based areas, has helped in understanding of this process.

In order to discover when this occurred in the case of Brazil, a research was conducted in a period prior to the Great Navigations, as the Portuguese, main colonizers of Brazil, already had a rich cultural background that was fundamental in the establishment of alimentary foundations in the colony. It was verified that the need to overcome initial difficulties led the colonizers to adopt indigenous habits, but mainly their farming techniques and their foods; the substitution of European ingredients for similar ones in the colony was a second important step; the third element was the Negro slave, who later added their knowledge to the cuisine of large farms, resulting in a unique eating habits, based on manioc flour, corn and its derivatives, beans and dry meat.

Despite all this, the colony maintained a poor diet in many regions due to lack of products originating from Portugal and its increasing prices, insufficient agricultural subsistent activity and the poor transportation facilities for foods to move distant regions, as well as the drastic population increase, mainly in the region marked by mines. 
Finally, it was observed that this alimentary situation, characterized by misery, improvisation and creativity resulted, among other things, in a endemic scenario of subnutrition that can be seen nowadays in many parts of Brazil. On the other hand, it has contributed towards the formation of the typical and renowned cuisine of Bahia and Minas Gerais, true cultural gems of the country.

Descriptors: Alimentary history in Brazil. Colonial food. Alimentary habits in Brazil. 


\section{ÍNDICE}





1.1 - OBJETIVO E METODOLOGIA................................................................. 7

2 - OS FUNDAMENTOS EUROPEUS DA ALIMENT AÇÃO COLONIAL...... 9

2.1 - A COZINHA MEDIEVAL_.......................................................................... 17

2.2 - VIDA E ALIMENTAÇÃO NAS EMBARCAÇÕES PORTUGUESAS

DOS SÉCULOS XV E XVI................................................................. 39

3 - ENTRECRUZAMENTO DE RAÇAS, CULTURAS E EXPERIÊNCIAS ALIMENT ARES NA AMÉRICA PORTUGUESA ……………………......... 61

3.1 - O BRANCO



3.3 - O ÍNDIO

3.3.1 - O uso dos recursos naturais: caça, pesca e coleta.......................... 84

3.3.2 - A lavoura indígena: presentes da natureza.................................... 92

3.3.3 - Costumes alimentares, culinária e utensílios................................. 98



4 - O MUNDO COLONIAL: BASES PARA A FORMAÇÃo DA BRASILIDADE ALIMENT AR...................................................................... 107

4.1 - A INFLUENCIA AFRICANA NA COZINHA DAS REGIÕES



4.2 - A ALIMENTAÇÃO NA REGIÃO DAS MINAS......................................... 125 
4.3 - ALGUMAS HERANÇAS NEGATIVAS PARA A ALIMENTAÇÃO NO BRASIL

4.4 - CONTRIBUIÇÕES ESTRANGERIAS: AS DUAS VIAS DAS INFLUÊNCIAS ALIMENTARES...

5 - COMENTÁRIOS FINAIS. 150

6 - REFERENCIAS. 161

ANEXO

GLOSSÁRIO A-1 


\section{ÍNDICE DE FIGURAS E TABELAS}

\section{FIGURAS}

Figura 1 - Afresco da tumba do faraó Senefer: cenas da navegação.......... 10

Figura 2 - O Resplendor de Constantinopla em sua arquitetura: cúpula da Basílica de Santa Sofia............................................................. 12

Figura 3 - Vítimas da peste negra no século XIV ...................................... 16

Figura 4 - Plataforma de pedra onde se colocava a lenha para o fogo.... 19

Figura 5 - Ganchos suspensos e a panela tripé.......................................... 19

Figura 6 - Panela suspensa sobre o fogo com os ganchos graduados..... 20

Figura 7 - Forno medieval....................................................................... 21

Figura 8 - O Cozinheiro das casa nobres medievais................................ 24



Figura 10 - Animais de caça usados na alimentação..................................... 26

Figura 11 - Mercado de peixe e frutos do mar......................................... 27

Figura 12 - O "Casamento camponês" ..................................................... 29

Figura 13 - Plantações de gêneros alimentícios próximos às casas na Idade Média.............................................................................. 33

Figura 14 - Aves domésticas e de caça abatidas para alimentação.............. 35

Figura 15 - Ilustração do local das refeições a bordo dos navios................ 40

Figura 16 - Captura de uma tartaruga para alimentação a bordo................ 42

Figura 17 - Forno portátil usado durante a Idade Média, provavelmente adaptado para uso em embarcações............................................ 44

Figura 18 - Ilustração de um navio sendo abastecido no porto antes da partida....................................................................................... 45

Figura 19 - Mapa do itinerário de Cabral em sua expedição de 1500.......... 51 
Figura 20 - Animais a bordo destinados a alimentação.

Figura 21 - Ilustração de um abrigo usado pela tripulação para se proteger do tempo....

Figura 22 - Barris armazenados nos navios. 58

Figura 23 - Gengivas inchadas e inflamadas pela presença do escorbuto.. 65

Figura 24 - Casa grande de taipa coberta de palha, no século XVII............ 69

Figura 25 - Interior de uma casa colonial................................................... 70

Figura 26 - "Passatempo dos ricos" ..................................................... 72

Figura 27 - Engenho de açúcar do século XVII........................................... 73

Figura 28 - Engenho de açúcar do século XVII.......................................... 74

Figura 29 - Captura de índios pelos bandeirantes.......................................... 77

Figura 30 - Embarque de escravos nos porões dos navios negreiros......... 80

Figura 31 - Venda de escravos no mercado colonial.................................. 80

Figura 32 - Senzalas do século XVIII..................................................... 82

Figura 33 - Índio brasileiro do século XVII............................................ 83

Figura 34 - Uma caçada indígena.......................................................... 85

Figura 35 - Ilustração de índios pescando................................................ 86



Figura 37 - Ilustrações da flora brasileira.................................................. 92

Figura 38 - Elementos da flora brasileira....................................................... 94

Figura 39 - Escrava negra vendendo milho assado no mercado................. 102

Figura 40 - Índias tupinambás usando seus potes de barro........................ 103

Figura 41 - Utensílios de madeira e barro.................................................. 105

Figura 42 - As etapas da necessidade alimentar........................................ 108

Figura 43 - Escravas negras vendedoras de leite....................................... 117 
Figura 44 - Transporte da carne de corte.................................................... 118

Figura 45 - Jantar na casa colonial............................................................ 121

Figura 46 - Negras vendendo angu......................................................... 123

Figura 47 - Negras vendedoras de quitutes............................................. 124

Figura 48 - Casa colonial, típica da região das minas................................ 125

Figura 49 - Pequeno núcleo urbano, na região das minas............................ 126

Figura 50 - Escavações para procura de ouro e diamantes......................... 127

Figura 51 - A procura de ouro na região das minas.................................... 128

Figura 52 - Produção de farinha de mandioca pelos escravos..................... 131

Figura 53 - Demonstração gráfica do consumo de hortaliças e frutas, em $\mathrm{kg}$ por ano, em algumas capitais brasileira, nos anos de 1995/1996.

Figura 54 - Guia alimentar, segundo grupo de alimentos e recomendações diárias.

\section{TABELAS}

Tabela 1 - Cálculo aproximado da ração alimentar diária em caravelas do século XVI, segundo MENEZES e BUENO............................ 52

Tabela 2 - Número de escravos negros desembarcados na Europa e nas Américas durante os séculos XVI ao XIX.

Tabela 3 - Cesta básica Dieese \& Procon, segundo os produtos e suas quantidades.

Tabela 4 - Gastos relativos à compra de itens alimentares, em salários mínimos, nas principais capitais do Brasil, no ano de 1996

Tabela 5 - Distribuição dos alimentos típicos, segundo regiões no Brasil. 


\section{PREFÁCIO}

Esta tese representa o esforço de 5 anos de trabalho que foram permeados por dificuldades e prazeres. Tem como intuito principal fornecer um texto esclarecedor $e$ que possa contribuir, principalmente aos profissionais da saúde, com um novo conhecimento, fruto de metodologia de pesquisa não ortodoxa e que envolve várias áreas do saber, mas principalmente a História e a Nutrição.

Um texto com esta natureza hibrida pode suscitar questionamentos principalmente quanto a forma como é apresentado. Assim sendo, cabe esclarecer que este texto encontra-se estritamente dentro dos padrões de apresentação de teses da Faculdade de Saúde Pública da USP, tanto para citação quanto para referências. Este padrão está expresso em um manual próprio, sendo este mesmo fruto de acordos internacionais com outras instituições.

As figuras apresentadas generosamente ao longo do texto servem para ressaltar aspectos relacionados ao cotidiano das populações apresentadas, além de representar maior suporte bibliográfico, já que por si apenas representam importante fonte de informaçōes.

A linguagem e a apresentação do texto procuraram contemplar e conciliar, dentro do possivel, características de ambas as principais áreas envolvidas. A estrutura geral do trabalho segue uma linha cronológica.

Na Introdução são apresentadas as justificativas para a elaboração de um trabalho desta natureza, citando trabalhos pioneiros para avaliação do consumo alimentar em uma dada população com base em dados históricos. Apresenta, também, o objetivo do trabalho, bem como a metodologia empregada.

O segundo capítulo dá um panorama do desenvolvimento das condições de vida desde a antigüidade, passando a enfocar as questões do cotidiano europeu e os fatores que influenciaram seu modo de vida. Situa de maneira mais específica a 
questão da alimentação, destacando os aspectos mais técnicos e dos costumes alimentares, dando ênfase ao Portugal do final do século XV. Expõe, também, algumas questóes do abastecimento, bem como os alimentos que eram disponíveis de alguma forma naquela época. E como parte importante da história de Portugal, a questão das embarcações, também, foi abordada neste capítulo. Criou-se neste meio de transporte uma nova cultura que afetou direta $e$ indiretamente, não só os portugueses, como também aqueles que mais tarde habitariam a colônia, já que muito do que era aqui consumido, vinha por mar. A tecnologia adquirida aos longo da exploração da costa africana permitiu não só que Vasco da Gama chegasse às Índias como que Pedro Alvares Cabral chegasse também ao Brasil.

O terceiro capítulo aborda mais diretamente a miscigenação das raças aqui envolvidas, índios, negros e brancos. Para isso, apresenta as características mais gerais de cada grupo - características essas que dizem respeito a suas experiências alimentares.

O quarto capítulo trata de questões mais especificamente ligadas às condições de abastecimento no período colonial, destacando as muitas tentativas sem sucesso para manter estável o abastecimento. As palavras chaves poderiam ser "mistura" $e$ "adaptação": não só as raças e costumes se mesclaram, mas começaram a dar origem, como numa fecundação, a novos elementos. A capacidade de superar dificuldades passou a ser a marca registrada dos habitantes da colônia; estas seriam, também, as características da alimentação. São abordados, também, o início das cozinhas baiana e mineiras, descrevendo suas características básicas, evidenciando os novos costumes alimentares, algumas heranças negativas para a alimentação no Brasil, finalizando com a dupla via que tiveram as influências alimentares em todo o mundo da época.

Por fim, alguns comentários finais, as referências usadas no trabalho, bem como um pequeno glossário com alguns vocábulos antigos ou mais técnicos, que ajudarão na melhor compreensão do texto aqui apresentado, além de biografias de personagens presentes ao longo da narração do trabalho. 


\section{1 - INTRODUÇÃO}

"Se alguns homens podem governar estados, pesquisar a verdade, fazer música, esculpir estátuas, pintar, escrever livros, ensinar crianças ou servir aos deuses, é porque outros lavram a terra para a produção de alimentos..." (DURANT 1943, p. 345)

Talvez, por ser algo tão fundamental à vida, a alimentação não mereceu destaque nas crônicas e documentos de épocas mais antigas. Aparentemente isto representaria um paradoxo, mas a verdade é que não há informações sobre hábitos alimentares de maneira precisa e detalhada.

Por exemplo, a citação dos alimentos em Portugal no período medieval é muito generalista. MACHADO (1984) chega até a comentar:

“... surpreende-nos que tão pouco se diga acerca dos usos e costumes dos nossos antepassados, através dos séculos. Faz-se algumas vezes alusão à sua indumentária, mas pouco ou nada se diz acerca da sua alimentação, onde e como cultivavam esses alimentos, como os cozinhavam e condimentavam, que refeições usavam, que alimentos preferiam (...) . Que alimentos utilizavam os portugueses no tempo de D. Afonso Henriques? Eram os mesmos com que nós hoje nos alimentamos? Eram alimentos cultivados ou criados em Portugal, ou eram alimentos importados de outros povos? Entraram em Portugal, no decurso de oito séculos, novos alimentos, até então desconhecidos? Quais foram esses alimentos novos? ". [...] "Queremos acrescentar ainda ser nosso desejo que o presente ensaio represente apenas o ponto de partida para averiguações mais profundas, sobre um tema que julgamos tão atraente e interessante" (p. 508 e 509).

Isso não é diferente para o Brasil colonial. As informações sobre os costumes alimentares estão dispersas nas crônicas e nos depoimentos de 
visitantes europeus, na sua maioria, que narravam os fatos como lhes convinha. Toda a análise do consumo alimentar, bem como todos os dados a este relacionados, estão, portanto, condicionados a citar a ótica européia da época, já que os índios não escreviam. MESGRAVIS e PINSKY (2000) relaciona estas fontes documentais de maneira didática, o que possibilita enxergar que para se escrever sobre como era a alimentação no período colonial, pode-se contar basicamente com menos de vinte indivíduos, divididos em autores jesuítas ou clérigos, colonos, burocratas e estrangeiros viajantes.

Esta consideração torna-se necessária, pois, ao se comparar estas narrativas, percebe-se que algumas informações podem ser fantasiosas. Já na segunda metade do século XVI apareciam sátiras, das quais a mais famosa talvez seja a de Rabelais. Ele considerava um disparate as descrições que alguns faziam sobre suas aventuras no mar e em novas terras. Bastava olhar as gravuras que descreviam alguns monstros para se concluir isso. Por outro lado, sabe-se que é possível ter-se alucinações em casos de calor extremo e fome. Talvez por isso mesmo acreditavam piamente no que diziam.

\section{O que seria verdadeiro?}

Para tentar satisfazer a esta pergunta foram incluídos neste trabalho textos variados que abrangem desde como era a cozinha medieval na Europa e em Portugal, passando pelo período das grandes navegações, chegando, enfim, a América portuguesa, mais tarde, o Brasil. Estes textos foram acrescentados com o interesse de oferecer ao leitor subsídios para constituir mentalmente quem eram as pessoas, os indivíduos que colonizaram este país, por que vinham para cá e o que enfrentavam para isso.

Desfazer-se, portanto, temporariamente, de todos os conceitos modernos de vida, valores morais, entre outras coisas, é uma tarefa difícil, mas que propicia ao leitor a oportunidade de entender atitudes e práticas 
remotas. Talvez, deste modo, seja possível compreender porque o sistema colonial priorizou a obtenção de lucro para a Coroa portuguesa (questões políticas) ao invés de investir no desenvolvimento da colônia, já o "lar" de muitos portugueses.

Associada a estes, ainda, está a questão da mistura racial. Não apenas a mistura de brancos, índios e negros, mas as próprias tribos e nações entre si.

Usando a linguagem da cozinha: misture todos esses ingredientes em uma grande panela de pressão e leve ao fogo por todo o período colonial, acrescentando, de vez em quando, uma grande jibóia comedora de gente, os bandeirantes caçadores de índios, a descoberta de diamantes no interior do continente e algumas coisas mais. Guerras e revoluções não poderiam deixar de existir.

Mas como fica a alimentação diante de tudo isso? É possível descrever a alimentação dos indivíduos que lançaram as estacas desta nação? Autores como Gilberto Freyre e Luis da Câmara Cascudo têm obras excelentes que tratam deste assunto. Mas o enfoque deste trabalho não é apenas descrever fatos, e sim, ir um pouco mais além e analisar a relação, por exemplo, destes fatos com questões de outra natureza, como os aspectos culturais, e tentar apresentar, por meio de uma sucessão cronológica, como foram estabelecidas as bases do modo brasileiro de se alimentar.

A abordagem histórica, portanto, longe de pretender discutir aspectos reservados unicamente aos historiadores, se propõem apenas a localizar, esses fatos, no tempo e no espaço, apresentando o cenário onde eles se passaram, fornecendo com isso mais subsídios para compreender o tema aqui discutido. Ela serve, também, como um "refresco" à memória dos que não tem tanto contato com este assunto, já que é um trabalho que associa as duas áreas, Nutrição e História. 
Essa importância de estudos multidisciplinares tem se mostrado como uma forte tendência de pesquisa para esse novo século século. Universidades, como a de Colúmbia, em Nova Iorque, e a de Paris, na França, têm demonstrado um maior interesse para compreender e identificar fatores que determinam ou influenciam as mudanças dos hábitos alimentares. Os métodos clássicos de abordagem do tema tem-se mostrado insuficientes, segundo eles. A importância de se ampliar os horizontes de pesquisa nesta área podem ser observados em muitos trabalhos publicados nas décadas de 80 e 90, conforme OLIVEIRA E THÉBAUD-MONY (1997), que citam pelo menos seis autores de diversas áreas.

O Instituto de Pesquisa das Nações Unidas para o Desenvolvimento Social (conhecido pela sigla UNRISD), propôs para o final do século $X X$ a noção de um novo conceito, o de "sistemas alimentares", ou seja, a análise da alimentação em função dos processos de produção e de consumo, bem como de todas as etapas intermediárias, dentro do contexto da sociedade. Para OLIVEIRA E THÉBAUD-MONY (1997) “esse tipo de abordagem, que estuda o consumo alimentar a partir de seus determinantes, considerando os aspectos de ordem econômica, social, nutricional e cultural, permite compreender as evoluções no sentido do modelo [de alimentação] dominante e, ao mesmo tempo, suas variações e adaptações. A história também faz parte das áreas de conhecimento interessadas em aprofundar a análise do consumo alimentar, em função do contexto sócio-econômico ou dos fatores que determinam sua evolução" (p. 203).

O sistema alimentar seria, então, a visão panorâmica de todos os fatores históricos, políticos, geográficos, temporais, etc. que influenciam e/ou contribuem para o estabelecimento das bases alimentares regionais, que no caso do Brasil acabam se diferindo de uma região para outra: na visão de um baiano, por exemplo, não existe refeição sem a farinha de mandioca. $O$ 
gaúcho poderá discordar. Para ele o importante mesmo é um bom pedaço de carne, mas não carne seca!

Assim sendo, parece recomendável que para se determinar qual o hábito alimentar de uma determinada população é necessário investigar aspectos variados, entre eles os históricos e antropológicos (CANESQUI 1988), indo além da dimensão biológica da questão nutricional. Só assim a análise alimentar pode ser completa e conclusiva. A expressão "sistema alimentar" brasileiro, portanto, é útil já que se diferiria de "hábito alimentar brasileiro", a qual não distingue o brasileiro do sul e o do norte, que, como se sabe, têm alimentos distintos na base de sua alimentação.

Olhando a alimentação por este prisma é possível, também, identificar outros elementos que atuam na sociedade, já que a visão se torna mais ampla. A falta de disponibilidade de alimentos numa dada região, por exemplo, pode ocasionar enfermidades endêmicas, como foi o caso do bócio, e por outro lado pode mostrar o aumento do sedentarismo em um determinado grupo pela comodidade gerada por uma infra-estrutura favorável.

Deste modo, essa tendência de análise e interpretação de dados relativos à alimentação coincide oportunamente com uma nova visão para se avaliar a vida. Segundo artigo do jornal Estado de São Paulóa, para a Organização Mundial da Saúde (OMS) não basta apenas viver muitos anos, e sim, como se tem vivido essa vida. $O$ termo que define essa nova visão é "expectativa de vida saudável", ou seja, um indicador que mede, de forma contínua, todos os processos relativos à saúde da população. $\mathrm{O}$ tempo gasto com enfermidades, seqüelas graves, cegueira, paralisias, surdez, invalidez, etc., além de outras causas como mortes por homicídio, AIDS, consumo de tabaco, são contabilizados negativamente.

\footnotetext{
¿ "O Estado de São Paulo", 05 de Junho de 2000.
} 
Pelo lado positivo estão as atividades físicas regulares, que aumentam a disposição e a força muscular, capacitando o indivíduo a realizar tarefas básicas que outros, mais sedentários, não realizam. Isto, por sua vez, melhora a auto-estima destes indivíduos, o que, ao final, resulta em uma melhor qualidade de vida.

Relacionada, também, à qualidade de vida está, sem dúvida, a qualidade da alimentação. Defendida há muito tempo por uma linha de nutricionistas, e agora por cardiologistas, está a certeza de que uma alimentação saudável pode ser muito saborosa. Apostando nesta tendência estão muitos chefs de cozinhas internacionais que fazem da gastronomia não só um aliado do prazer como, também, da saúde e longevidade, a chamada Nouvelle Cuisine, que busca usar alimentos mais naturais e receitas com menos gordura.

A alimentação neste caso não ocupa, portanto, apenas o papel de "supridora" de nutrientes, nem tampouco proporciona apenas alimentos deliciosos que ingeridos diariamente podem representar um grande risco para a saúde. Ela ocupa uma posição que proporciona, também, lazer, cultura e educação.

Valorizar a memória e a história de um povo faz parte do descobrir a cidadania. Alguns livros publicados por personagens importantes da sociologia, antropologia, história e jornalismo tem tido como tema principal a alimentação. Citando alguns: Arqueologias Culinárias da Índia, A Saga da Comida - Receitas e Histórias, História da Alimentação, A Cozinha do Arco da Velha, etc. Isto demonstra, por parte destes profissionais, o reconhecimento da importância que têm a alimentação na história de um povo.

Cabe, portanto, aos pesquisadores da área de Nutrição das futuras gerações dar a devida consideração a esses temas, aprendendo a olhar a alimentação não como um elemento destacado da vida dos indivíduos, mas 
um ponto importante que se relaciona com todas as demais áreas da vida humana.

\section{1 - OBJETIVO E METODOLOGIA}

O objetivo deste trabalho é expor de maneira cronológica eventos, descritos nas narrações históricas, que de alguma maneira influenciaram e/ou determinaram, positiva ou negativamente, a alimentação praticada durante os primeiros séculos de história desta América portuguesa, e que, consequentemente, passaram a representar a essência da brasilidade alimentar.

A metodologia utilizada foi a pesquisa bibliográfica e documental, que, como o próprio nome sugere, trabalha com livros, documentos de época, artigos e similares, ou as chamadas "fontes de papel" (GIL 1995), além de outros, como pinturas e gravuras, modernamente considerados como documentos e fontes de informação. Os limites temporais foram os séculos XIV e XVIII.

A pesquisa se deu em quatro etapas:

1 - Levantamento bibliográfico de livros e documentos que tivessem qualquer relação com o tema: Foram incluídas neste levantamento material de bibliotecas do estado de São Paulo, Rio de Janeiro e Bahia, além de outros de coleções particulares, gentilmente cedidas por seus colecionadores.

2 - Pré-análise e seleção: Nesta etapa ocorreu a primeira seleção das fontes quanto ao seu conteúdo, pela leitura rápida, ou "flutuante". Esta foi a fase mais árdua, já que significou uma verdadeira garimpagem por milhares de páginas de textos. 
3 - Organização e sumarização: Os textos selecionados foram divididos segundo o assunto principal: Europa medieval, Portugal medieval, grandes navegações, Brasil colônia, etc., e em sub itens como culinária, abastecimento, alimentos mais comuns, etc. A reunião destes dados visaram o fornecimento de resposta à pergunta chave deste trabalho, ou seja, quais seriam os fenômenos que de alguma forma contribuíram para a formação da brasilidade alimentar.

4 - Elaboração do texto final aqui apresentado.

Vale destacar que a principal dificuldade encontrada para a elaboração deste trabalho foi a escassez de material desta natureza no Brasil. Tanto pelo lado de profissionais da saúde quanto dos historiadores são raros os que se propõem a realizar estudos alimentares com base em informações históricas, sendo os existentes limitados à chamada história da medicina. 


\section{2 - OS FUNDAMENTOS EUROPEUS DA ALIMENTAÇÃO COLONIAL}

O primeiro espaço físico que se tem notícia da presença do homem foi a Mesopotâmia, região muito fértil, cercada de rios e planícies. $O$ homem logo percebeu que o melhor seria fixar residência junto a locais como este, por serem fontes de alimentos. Para lá iam mamíferos e aves em busca de água, o que lhe fornecia a caça, além da variedade de peixes e alguns répteis. Surgem as primeiras tentativas de agricultura.

Há indícios de que o homem aprendeu a lidar com a terra por volta de 10.000 anos antes de Cristo (AHT, 1995). O que se pode afirmar é que pela aquisição desse novo conhecimento foi possível obter mais provisões para os integrantes das antigas comunidades, levando a um aumento natural do número de indivíduos. Esses, por sua vez, podiam ter uma expectativa maior de vida e, portanto, também, maior oportunidade para colocar em prática os conhecimentos adquiridos pelas gerações passadas, gerando com isso mais conhecimento.

Esta nova prática possibilitou a jornada para outras regiões, o aparecimento de vilas e posteriormente cidades. Novos conhecimentos como a escrita, astronomia, engenharia e náutica, foram surgindo; as artes desabrocharam; interligações entre as cidades originaram o comércio e a troca desses conhecimentos e práticas foram se espalhando e amadurecendo, e resultaram no aparecimento de civilizações fantásticas, que deixaram uma rica herança cultural.

Os egípcios, por exemplo, tinham um avançado senso das estações, e as aproveitavam para suas plantações. Por volta de Junho o rio subia e encharcava as suas margens, deixando-as férteis para o plantio. Por volta de 
Outubro, quando o nível do rio estava baixo, eles plantavam. O rio era considerado para eles como o pai das famílias (MUNDO ANTIGO, 2001d). A Figura 1 mostra um barco egípcio, provavelmente navegando pelo Nilo.

Figura 1 - Afresco da tumba do faraó Senefer: cenas da navegação.



Fonte: MUNDO ANTIGO, 2001d.

Há na Bíblia a história de José, filho de Israel (pai da nação de mesmo nome), que ocupou um importante cargo, sendo considerado o segundo homem mais importante no Egito. Ele interpretara um sonho do Faraó que previa sete anos de muita abundância seguidos de sete anos de muita miséria. Plantaram e juntaram em silos o fruto de suas colheitas durante os primeiros sete anos. Após estes, vieram os anos da fome e o Egito podia vender parte de seus estoques a muitas nações vizinhas (Livro do GÊNESIS, cap. 41). 
É atribuída aos egípcios, também, o uso do fermento nos pães, o que certamente melhorou seu sabor e aproveitamento. $O$ pão era a base da alimentação. Era tão importante que passou a ocupar um papel quase como de uma moeda: muitos trabalhos eram assim pagos. Nas tumbas dos Faraós, os pães eram depositados para garantir alimento para suas almas. Costumavam considerar uma grande ofensa negar pão a quem quer que seja (LOWENBERG et al. 1970).

O Egito tinha como principal atividade econômica a agricultura, com irrigação através dos diques, canais e reservatórios. Cultivavam o trigo, o cânhamo e a cevada e criaram a técnica da rotatividade do solo. Fabricavam o vidro, tecidos e papiro (MUNDO ANTIGO 2001d).

Destacaram-se na astronomia, criando o calendário lunar; na arquitetura, construindo palácios, pirâmides e templos; na Matemática, lançando os fundamentos da Geometria. Desenvolveram a escrita hieróglifa.

Com o passar do tempo o comércio passou a ser praticado de maneira desenvolvida em outros lugares, e em muitos países já havia o hábito de longas viagens, por terra ou pelo Mediterrânneo, para obter vários produtos que podiam ser vendidos nos centros urbanos. Isso, mais tarde, acabou por distribuir alguns produtos, antes desconhecidos, a muitas regiões tornando o seu uso mais difundido.

FRANCO JÚNIOR (1989) fala, por exemplo, que "Constantinopla foi, sem dúvida, o grande centro urbano da Europa Medieval. Todos que para ela fluíam espantavam-se com sua grandiosidade e riqueza (um exemplo dos mais imponentes é a Basílica de Santa Sofia, como ilustrado na Figura 2). Um deles, ocidental, sobre ela diria ...é uma grande cidade de negócios; os comerciantes chegam a ela de todos os países do mundo; excetuando Bagdá, não existe no universo cidade alguma que a ela se possa comparar...." (p. 48). 
Durante muito tempo, Constantinopla não foi apenas a capital do Império Romano do Oriente, mas a capital da comunidade mediterrânea. Em seu porto, mercadorias de diversas procedências se aglomeravam. Os mercados e feiras que aconteciam em toda a Europa tinham produtos desta procedência.

Figura 2 - O Resplendor de Constantinopla em sua arquitetura: cúpula da Basílica de Santa Sofia.



Fonte: MUNDO ANTIGO 2001c.

Considerando a formação histórica da Europa no que diz respeito à alimentação, o período mais relevante seria o da "plena" (séculos XI a XIII) e "baixa" Idade Média (séculos XIV e XV). Para MONTANARI (1998) essa diferenciação se dá principalmente "porque os modos de produção e os modelos de consumo diferem consideravelmente de um período para outro 
(p. 382). Para ele a estabilidade desfrutada nos períodos anteriores começava a sofrer perturbações que iriam caracterizar os tempos modernos.

Muitos historiadores costumam definir a Idade Média como a "Era das Trevas", mas após uma detalhada observação em todos os fatos e acontecimentos, pode-se dizer que isso não é totalmente verdadeiro (OLIVEIRA 1990).

A sociedade medieval foi, sem dúvida, fortemente marcada pela religião - com reformas e contra-reformas, bem como a Inquisição - mas, também, foi uma época de profundo relacionamento entre o homem e a terra; esta era o seu sustento e, desta forma, aprender a trabalhá-la foi fundamental para a subsistência. São atribuídos a este período a invenção do arado, do moinho d'água e de vento, bem como dos teares (OLIVEIRA 1990). O uso de tais inventos foram fundamentais para o desenvolvimento da agricultura em locais não privilegiados naturalmente, facilitando, assim, a expansão de terras habitadas. Entretanto, tais avanços não seriam suficientes em tempos posteriores ao século XIII.

Com as cidades houve o aumento da concentração populacional em áreas limitadas, principalmente nas regiões portuárias o que, associado à falta de conhecimento das práticas básicas de higiene e saúde, propiciaram o aparecimento de muitas doenças e pestes, que acabaram dizimando parte da população medieval. Apenas Lisboa, na peste de 1569, perdeu nos meses de Julho a Setembro cerca de 50.000 pessoas, o que eqüivalia à metade de seus habitantes (ROQUE 1982).

Quanto aos aspectos culturais surgem pequenos indícios de mudanças: apesar do castelo e convento serem os símbolos desta época, temse, por outro lado, a criação de um dos maiores patrimônios da humanidade: a Universidade. Surgem várias, entre elas, Praga, Pádua, Bolonha, Salamanca, Paris, Montpellier, Oxford, Cambridge e Viena (OLIVEIRA 1990). 
Seus estudiosos, mais tarde, começariam a redescobrir autores clássicos como Aristóteles, Platão, entre outros. A batalha entre religiosos conservadores e os mais modernos estava travada. Uma amostra do que seria este novo pensamento ocidental, especialmente nos últimos 300 anos da Idade Média, pode ser exemplificado no período compreendido entre 1210 , com um sínodo parisiense, que declarou inconveniente a obra Libre naturales, até que fosse corrigida e 1323, com a canonização de Tomás de Aquino, que levou à amenização da censura de opiniões especulativas que não fossem reconhecidas como falsas teologias. Tomás de Aquino conciliava a fé com a possibilidade de explicar fenômenos de maneira racional; os fenômenos naturais não eram mais vistos por ele apenas como a vontade de Deus, e sim como a obra sábia de um criador que estruturou tais fenômenos de modo a serem aprendidos. Foi aceito inicialmente e, depois, totalmente repelido (MORSE 1995).

A exaltação do caráter e da lealdade, bem como a falta desses, são muito abordados na literatura que remonta fatos da época, para não citar os casos de bruxarias e práticas da magia negra, fortemente proibidos mas convenientemente aceitos em determinadas circunstâncias, como para obter perdão ou recuperar o cônjuge perdido (MORENO 1994) . Esses fatos podem evidenciar que a religião imposta aos fiéis não era suficiente para mantê-los longe de heresias e sacrilégios, podendo-se ver, por meio de uma lente crítica, que os homens aprenderam a usurpar o poder e a autoridade em seu próprio benefício, oprimindo e manipulando a fé e crença populares, mantendo, assim, sua autoridade a salvo das insurreições.

No plano social instituíram-se os feudos, determinando os papéis sociais de forma bem clara: os escravos, que não tinham muito valor, o servo de terra, que possuía uma família em uma pequena propriedade, onde desenvolvia sua agricultura de subsistência, além do senhor feudal que 
dominava as relações econômicas e sociais, sendo ele, por sua vez, subordinado ao rei.

Os europeus medievais, entretanto, não eram tão adiantados como os povos do Oriente, que já utilizavam várias técnicas na criação de animais e agricultura. Esses já dominavam desde a Antigüidade a arte da adubação e da irrigação. Com essa última era possível levar água por quilômetros de distância até as áreas mais necessitadas. A adubação era desempenhada por indivíduos especializados, que contavam, dentro do governo local, com uma repartição dedicada aos problemas técnicos desta área. Para ilustrar, o uso do moinho de vento na Europa, datado do século XII, já era usado no Oriente há muito tempo (GIORDANI 1985).

A Europa sofreu grande impacto pelo binômio terra e clima, uma vez que as técnicas de cultivo e irrigação, bem como adubação, só foram suficientes para atender as necessidades dos indivíduos até meados do século XII, como anteriormente citado. E, talvez, grande parte desse sucesso, tenha sido devido à invasão e ocupação árabe na região da península Ibérica, em séculos anteriores. As sociedades dos séculos seguintes se basearam nessa bem sucedida economia, que pelo aumento do número de indivíduos, já não correspondia às novas demandas.

Todas essas circunstâncias, por sua vez, colocaram os habitantes de muitas regiões da Europa em sérias complicações; a população já era numerosa e o clima, muitas vezes, não se apresentava dentro dos padrões previstos para boas colheitas, surpreendendo com secas ou enchentes.

Mas nos séculos XIII e XIV o advento da peste só revelou um sistema de fornecimento de alimentos insatisfatório, diferente de como já o havia sido. Houve falta de gêneros, aumento dos preços e posteriormente carência de produtos. Com os mercados desabastecidos e a população necessitando de gêneros básicos, os indivíduos, menos nutridos, tendiam a desenvolver 
enfermidades, adoecendo e morrendo, como representado nesta gravura, sobre a peste negra do século XIV (Figura 3).

Figura 3 - Vítimas da peste negra no século XIV.



Fonte: MUNDO ANTIGO 2001b.

A diminuição da população praticamente ajustou novamente os recursos alimentares disponíveis. A partir deste momento não há mais relatos de estabilidade alimentar na Europa por períodos longos. Este quadro alcançará, inclusive grande parte do período colonial no Brasil, interferindo no próprio sistema de abastecimento.

Pode-se concluir, portanto, que a Idade Média foi uma época de contrastes que não começaram ou terminaram em si mesmos: foram a combinação de muitos fatores de tempos anteriores, de relações entre povos e reinos, que lutaram, guerrearam, ora sendo conquistadores, ora conquistados. 
Trata-se de uma época de muitos contrastes: guerra, paz, doenças, pestes, religião, instituição e queda de reis, invasões e retomadas, conquista de novos espaços. A Europa não estava sozinha no mundo: havia outros povos e novas terras, outros costumes e crenças. Tudo isso não poderia ser diferente, uma vez que se tratam de aproximadamente 1.000 anos de história. E é neste contexto que a América e o Brasil são descobertos.

\section{1 - A COZINHA MEDIEVAL}

Durante muitos anos, até fins da Idade Média, a cozinha européia era de modo geral muito simples, e na maioria das casas dos camponeses as heranças greco-romanas já tinham sido esquecidas (MARQUES 1974). O requinte e sucessão de eventos que marcavam as refeições dos antigos povos romanos foram substituídas pela dura e rude realidade do cotidiano camponês.

ROBERT (1995) faz referência à antiga cozinha romana. Segundo ele “A cozinha é uma arte, e a evolução da arte culinária de um país reflete sua evolução econômica e histórica. Roma aprendeu a cozinhar, e os costumes evoluíram bastante desde o pastor que preparava seu cozido de frumento até os pratos servidos no jantar oferecido por Trimalcião" (p. 131). Vê-se o caso nesta receita elaborada por um cozinheiro romano do século II:

“Porquinho à jardineira

Desossa-se o porquinho à jardineira pela goela, como uma ostra. A seguir, é guarnecido de frango moído em almôndegas, de tordos, de papa-figos, de seus miúdos moídos, de salsichas da Lucânia, de tâmaras sem caroço, de bulbos secos ao forno, de caracóis sem casca, de malvas, de acelga, de alho-porro, de salsão, de brócolis cozidos, de coentro, de 
pimenta em grão e de pinhões. Acrescentam-se quinze ovos e garumb à pimenta - os ovos serão esmagados; volta-se a cozinhar o porquinho refogando-o, e depois é assado no forno. É cortado então nas costas e regado com o seguinte molho: pila-se pimenta, arruda, garum, vinho feito de uvas amadurecidas sobre a palha, mel e um pouco de azeite. No momento da ebulição, acrescenta-se a fécula" (ROBERT 1995, p. 136).

Nota-se aqui a riqueza de ingredientes que compõem este prato, o qual mexe com os sentidos de maneira interessante, misturando frutas, ovos e carnes. Mais à frente vê-se que este grau de requinte culinário só é documentado em Portugal por volta do século XV, ou seja, treze séculos depois, e com a intensificação dos contatos comerciais com o Oriente.

A cozinha européia medieval constava basicamente de uma plataforma de pedra onde se colocavam as madeiras para o fogo, como mostra a Figura 4, ou ainda um tipo de lareira; um caldeirão com tripé poderia ser colocado diretamente no fogo ou suspenso sobre ele por um gancho preso a um suporte preso à parede ou ao teto. Este gancho era de metal e continha, como a régua, uma espécie de escala, onde poderia ser encaixada a alça, possibilitando subir ou descer o caldeirão, controlando, assim, sua temperatura (LANGLEY 1996), como pode ser visto nas Figura 5 e 6.

\footnotetext{
b $\mathrm{O}$ garum era considerado um condimento nacional. Tratava-se basicamente de vísceras de peixes salgadas maceradas em potes expostos ao sol durante dois ou três meses. Tais entranhas de peixe se autodigeriam sob o efeito das diástases contidas nos tubos digestivos; para não estragar, era fortemente salgado, o que impedia a putrefação (ROBERT 1995, p.132) Era acrescentado como tempero a outros pratos.
} 
Figura 4 - Plataforma de pedra onde se colocava a lenha para o fogo.



Fonte: LANGLEY 1996, p. 18

Figura 5 - Ganchos suspensos e a panela tripé.



Fonte: LANGLEY 1996, p. 18 
Figura 6 - Panela suspensa sobre o fogo com os ganchos graduados



Fonte: COSMAN 1976, p. 12

Havia, ainda, ganchos menores, facas, colheres, escumadeiras (colheres com orifícios que permitiam a passagem de líquidos ou gordura) e garfos com os quais se mexia o conteúdo do caldeirão, ou principalmente para retirada das carnes. Estes podiam ser feitos de metal forjado ou de madeira.

Observando a descrição de algumas receitas do século XV pode-se identificar que existiam, também, fornos, onde se assavam e douravam pães e outras preparações (GOMES FILHO 1994), conforme mostra a Figura 7.

Com o passar dos tempos e a intensificação das grandes viagens, comércio e a própria cultura renascentista, muitas técnicas e novos costumes passaram lentamente a fazer parte dos hábitos domésticos. Verifica-se, então, a diversificação dos utensílios sendo comuns a citação de panelas e caçarolas, onde eram refogados e guisados os alimentos ao fogo, e as vasilhas ou tigelas, descritas para muitos fins, entre eles, o de misturar, marinar e assar, sendo que estas últimas correspondem hoje às formas. Há, ainda, referências 
sobre a diferença na altura e tamanho destes recipientes (GOMES FILHO 1994).

Figura 7 - Forno medieval



Fonte: COSMAN 1976, p. 68

Essa nova sofisticação pode ter passado a fazer parte da vida diária em muitas regiões, pois há citação de vários instrumentos usados, não mais para facilitar a vida de quem cozinha, mas sim para enfeitar e apresentar as preparações de modo mais agradável - e por isso mesmo uma sofisticação. Esses objetos são:

- objeto cilíndrico para abrir massas de pastel (hoje chamado de rolo ou pau de macarrão);

- peneiras, que serviam a vários fins, entre eles, escorrer alimentos fritos, coar caldos de carnes, etc. 
- instrumento cortante para moldar massas de pastéis em formas variadas (hoje chamados de moldes, muito comuns para modelar decorativamente os biscoitos);

- uso de papel absorvente para frituras;

- saco para modelar (também conhecido hoje como saco de confeiteiro). Este é um exemplo típico da sofisticação que a cozinha renascentista estava alcançando: punha-se a preparação, geralmente à base de ovos, dentro deste saco e pelo seu orifício deixava-se escapar a massa, normalmente dentro de água fervente ou gordura quente, obtendo-se, assim, fios ou formas de laços quando cozidos. Este princípio é usado até hoje na confecção dos famosos fios de ovos.

A partir desta época a cozinha italiana tomava a liderança quanto a atenção aos resultados que os aspectos visuais e sensoriais da boa alimentação podiam trazer. $O$ pensamento renascentista italiano dizia respeito a uma nova atitude diante da vida, expressa em todos os níveis, entre eles, a arte da boa mesa. A quantidade passava a ser substituída pela qualidade e as sensações experimentadas com um bom alimento eram cada vez mais valorizadas (FRANCO 1986). Para isso, dominar e incrementar as técnicas culinárias tradicionais tornou-se um importante aliado desta nova cozinha. Assar sobre o fogo ou fazer cozidos em grandes caldeirões, talvez os métodos culinários mais antigos, já não atendiam as expectativas destas novas tendências.

Considerar as técnicas de culinária, portanto, é quase tão importante quanto falar dos próprios alimentos, pois o seu uso inadequado pode estragá-los, alterando sabor e consistência, ou desperdiçá-los, sendo esses, muitas vezes, valiosos. LIMA (1977) afirma: "Na imensa gama de elementos que constituem o que se denomina genericamente de cultura, há que 
considerar a 'culinária' como inequívoca expressão do espírito humano" (p. 3).

A técnica culinária teria, desta maneira, papel importantíssimo na preparação dos alimentos. Ela pode tornar algo intragável em um manjar dos deuses, se bem empregada. Teoricamente falando, pode-se dividi-la em duas etapas: o pré-preparo e o preparo propriamente dito.

O primeiro tem por finalidade executar todas os procedimentos necessários com os alimentos na sua forma original, ou seja, lavar, limpar, descascar, escolher (para cereais e grãos de modo geral), cortar em pedaços grandes e pequenos (caso de aves preparadas por partes), picar, fatiar, bater, misturar, amassar e sovar (massas em geral), etc. (LANGLEY 1996), tornando, assim, a preparação dos pratos mais rápida e fácil. É um trabalho simples mas que exige paciência e destreza com instrumentos cortantes, como a faca. O segundo finaliza a preparação, conferindo-lhe suas características definitivas.

Na cozinha de uma pequena casa quem se encarregava de ambas as tarefas era geralmente uma mulher, ou ainda, a mãe da família. $O$ mesmo não ocorria nas grandes cozinhas das casas dos nobres ou palácios. $O$ responsável, que geralmente era um homem, ou o cozinheiro chefe, cozinhava e dava o toque final às preparações, como mostra a Figura 8. Era, nestes casos, auxiliado por seus ajudantes que pré preparavam os alimentos. 
Figura 8 - O Cozinheiro das nobres casas medievais.



Fonte LANGLEY 1996, p. 19.

Quando pequenos animais, como as aves, peixes e animais de caça menores estavam inclusos no cardápio do dia, sua limpeza aparece sendo feita dentro do ambiente da cozinha, como mostra a Figura 9;

No caso dos grandes animais o abate e limpeza eram feitos do lado de fora da cozinha dada a sua complexidade, uma vez que podiam causar bastante sujeira, como sugerem esses quadros do século XVII (Figura 9 e 10), do pintor Frans Snyders (1579 - 1657). Ele pintou muitas cenas de caças, e foi o primeiro pintor a se especializar em naturezas mortas e de animais. Seus quadros eram meticulosos e tentavam mostrar com a maior fidedignidade as cenas da vida real (MARTINS FONTES ED. 1997). 
Figura 9 - Cozinha do século XVI.



Fonte: FRANCO 1986, p. 68.

Nota-se, no canto esquerdo inferior e mais ao centro, animais recém abatidos, esperando serem limpos para o preparo. À esquerda, também, aves sendo assadas ao fogo.

Esta figura, especialmente, mostra que alimentos crus e cozidos eram tratados no mesmo ambiente, o que poderia ocasionar problemas de contaminações alimentares, ocasionando enfermidades, como intoxicações alimentares, resultando em diarréias e vômitos, comuns nestes casos. 
Figura 10 - Animais de caça usados na alimentação.



Fonte: OLGA'S GALLERY 2001.

Pode-se notar, neste quadro, a variedade de animais: coelhos, galos, gansos, cervos; ao fundo, à direita, a cabeça de um javali. Os peixes e mariscos, entretanto, eram separados, como mostra Snyders no quadro do mercado de peixes e mariscos (Figura 11).

Uma vez que os animais e outros alimentos estavam prontos para serem preparados, eram encaminhados à cozinha para o preparo, o que ao final, consiste em modificar a estrutura e textura dos alimentos, conferindolhes, assim, suas características finais, como já apontado, proporcionando a mudança do sabor. Um dos objetivos da dietética ${ }^{c}$ diz respeito a melhorar a capacidade que um alimento tem para ser digerido e absorvido (ORNELLAS 1963), basicamente através da cocção. Interessante notar a aplicação deste

c Dietética é o ramo da Nutrição que se ocupa da alimentação ou dieta. 
conceito, mesmo que de maneira empírica, por aqueles que preparavam alimentos para os doentes, como mostra esta receita:

“Frango para os hécticos

Criem separados uma dúzia de frangos, cujo único alimento consista de tigela de cágado, cozida ou cevada: esse alimento deverá ser sempre fresco. Diariamente cozinhe-se um frango em pouca água, até desmanchar. Em seguida esprema-se a carne, que saia todo o suco; coem o caldo e levem-no novamente à panela com uma colher de açúcar rosado (mascavo). Deixa-se ferver um pouco, coa-se novamente e está pronto o caldo" (GOMES FILHO 1994, p. 143)

Figura 11 - Mercado de peixe e frutos do mar



Fonte: OLGA'S GALLERY 2001

A prática, mais que o conhecimento científico, recomendava que um doente devia comer alimentos de fácil digestão (considerando muitas 
doenças da época, que não eram tratadas devidamente e debilitavam em muito o organismo do moribundo), preparando, assim, pratos e refeições que atendiam às necessidades imediatas do doente.

Dentre as técnicas de preparo utilizadas na época, as mencionadas pelo escritor do livro "Um tratado da cozinha portuguesa do século $\mathrm{XV}$ " (GOMES FILHO 1994) são: refogar (fritar rapidamente em pouca gordura), cozinhar, assar, fritar em gordura ou manteiga, escaldar (passar pela água fervente, principalmente ovos, inteiros ou só as gema), caramelar (passar por uma calda de açúcar), engrossar (tornar um caldo ralo mais espesso, geralmente feito à base de ovos, principalmente gemas, ou com pães velhos, os chamados "pães dormidos"), empanar (passar na farinha de trigo para fritar) e besuntar (passar manteiga sobre a superfície do alimento para lhe dar melhor cor ou sabor, neste caso amaciando carnes do peito de aves).

Os alimentos utilizados, bem como o modo de prepará-los, e a presença ou não de um cozinheiro, podiam evidenciar a classe social. A diferença mais marcante, entretanto, parece estar no consumo de carne. A caça era uma atividade da nobreza, que possuía terras para caçar. As classes mais baixas tinham a base de sua alimentação nos cereais e no vinho, sempre presentes até em dias de festa. Nota-se nesta próxima Figura, 12, um quadro de Pieter Bruegel, a simplicidade de um casamento de camponeses, em pleno século XVI.

Duas coisas chamam a atenção do observador: a primeira, a própria simplicidade da cena, onde são servidas tortas de cereais; não há novilhos, ou rezes, sendo assadas sobre o fogo como nos banquetes da nobreza; a segunda é o olhar faminto do tocador de gaita de fole. Provavelmente chamado para animar a festa, só receberia seu ordenado após a festividade. Bruegel, como diz a lenda, costumava se disfarçar para presenciar os acontecimentos do dia-a-dia camponês. Esta foi considerada a mais 
verdadeira e humana obra deste pintor (MARTINS FONTES ED. 1997), já que não houve poses, apenas um retrato da singela realidade.

\section{Figura 12 - O "Casamento camponês"}



Fonte: MARTINS FONTES ED. 1997, p. 71

No caso específico de Portugal, algumas características alimentares eram um pouco diferentes das demais regiões da Europa.

Portugal não era exatamente um grande produtor de cereais, por questões de solo e de clima. Há muitos relatos de grandes fomes e mortandades ligadas à falta de pão (ou trigo, por dedução). Isso não significava que Portugal não produzia cereal, e sim, que o cereal produzido não era suficiente. 
Há citações de produção de pães com outros tipos de cereal além do trigo. Havia pão de milhete (não o milho trazido das Américas e sim o milho miúdo), centeio e também cevada e aveia.

Aqui cabe um comentário técnico. Pão para ser pão tem que ter em sua estrutura química uma proteína chamada glúten, que apresenta características elásticas, dando ao pão sua consistência e textura adequadas (GRISWOLD 1992). O trigo, por excelência, é o melhor fornecedor de glúten na natureza e, portanto, o melhor para fazer-se pão. Mas outros cereais contêm uma parcela de glúten, mesmo que bem menor, de modo que, se não há farinha de trigo suficiente para fazer um pão, é perfeitamente possível acrescentar outro cereal, como aveia, centeio ou cevada, à massa, e o resultado seria um pão meio quebradiço, porém, com elasticidade suficiente para ser pão. Talvez seja este o caso do pão português.

Outro aspecto importante é que o glúten deve ser bem hidratado para alcançar o seu potencial máximo de elasticidade, mas essa hidratação não está no fato de por muita água, e sim incorporar a água às moléculas de glúten, através do processo de sova e descanso. Se esta mistura for acrescida de fermento biológico, ela crescerá sem se partir, formando uma bola que, após assada, torna-se o pão. Este processo de sova está sempre presente nas receitas de massas, o que certamente melhora a qualidade do pão, mesmo que o trigo não seja o seu elemento principal.

Os pães portugueses eram grandes e, segundo MARQUES (1974), pesavam entre 150 e 750 gramas. Durante muito tempo usou-se uma espécie de disco feito de pão como precursor do prato, o qual era consumido após a refeição.

De fato quem mais sofria com a falta de cereal eram os habitantes dos centros urbanos, incapacitados de produzirem o que precisavam consumir, ao contrário do campo. No interior, longe do aglomerado de gente, além de 
haver mais condições para o suprimento das necessidades de cereal, mais especificamente do trigo, havia sucedâneos (MARQUES 1974 e TAVARES 1992). Os portugueses do interior comiam castanha ao invés de pão, pelo menos metade do ano. Isto se confirma por esta receita:

\section{PÃO-DE-LÓ}

Com um quilo de açúcar faça uma calda. Assim que esta espelhar [ou ficar transparente], ajuntem-se algumas gotas de água-de-flor e tirem-na do fogo. Pele um quilo de amêndoas, soquem-nas um pouco, para que fiquem apenas pedacinhos, $\mathrm{e}$ misturem-nas na calda. Mexam tudo durante algum tempo, e a seguir levem o tacho ao fogo brando, mexendo sempre para que a massa fique bem alva. Ela estará cozida assim que de desgarrar da vasilha. Despejem a massa num tabuleiro molhado, ou untado com manteiga, alisando-a bem com uma colhe de pau, de modo que não fique muito grossa. Cortem-na em tabletes, na forma desejada" (GOMES FILHO 1994, p. 161).

Além disso, a base da panificação nos campos não era a farinha de trigo e sim a de milheto (já especificado anteriormente), centeio e cevada. Desta maneira, a mistura de farinhas para obter um pão de melhor qualidade, era muito freqüente: trigo e milho, trigo e centeio, trigo e cevada ou até três farinha juntas (MARQUES 1974). No Cancioneiro Geral há a denominação de broa ao pão de milho. Na colônia, esta capacidade de adaptar os ingredientes desta maneira, será útil para fazer o "pão da farinha de mandioca", como será visto a diante.

Grande parte da população produzia seus próprios pães, porém, nas cidades existiam os padeiros, que os confeccionavam, coziam e vendiam, em tendas ou a domicílio (MARQUES 1974) (note a Figura 7). 
As farinhas, também, serviam a outros propósitos. Eram usadas na massa de pastéis e empadas, engrossavam caldos de carne, confeccionavam biscoitos para os exércitos e armadas - este ocupará lugar de grande destaque como recurso alimentar nas viagens transoceânicas, como poderá ser visto adiante - e ainda na forma de papas, apenas misturadas com água e cozidas.

Das sessenta receitas colocadas no "Tratado da cozinha portuguesa do século XV" (GOMES FILHO 1994), dezenove eram referentes às hortaliças, sendo elas: compota de diacidrão (cidra), casquinhas (cidra), compota de pêssego, doce de limão, compota de pêra, perinhas dormideiras (pêras), doce de abóbora, talos de alface, diacidrão cristalizado, doce de flor de laranjeira, marmelada de ximenes, bocados (marmelo), compota de marmelo, perada, marmelada de D. Joana, pessegada e geléia de marmelo. É interessante notar que todas essas receitas estão no item de "receitas de conservas", o que sugere que a abundância destes frutos fosse aproveitada para outras épocas do ano. Este costume de fazer conservas também esteve presente durante todo o período colonial e se constituiu uma das preparações mais importantes, tendo sido apenas adaptada aos alimentos presentes na colônia, como o doce de mamão verde e o pé de moleque.

Provavelmente, as outras frutas eram consumidas na sua forma in natura, como se pode observar nas pintura de festas da época, onde a mesa estava repleta de frutas frescas.

"Já os poetas árabes cantaram os perfumes dos pomares de maçãs ou o colorido das cerejeiras do território português. Por isso, não é de se estranhar que os pomares fossem uma das riquezas do camponês medieval, embora pouco se saiba sobre as qualidades ou variedade da fruta ou número de espécies, ou o seu consumo" (TAVARES 1992, p. 100). Há citação de árvores de fruto plantadas perto das casas, quintais e hortas, destacando as cidreiras 
(o que confirma tantas receitas com este fruto), macieiras, pereiras, ameixoeiras, cerejeiras, pessegueiros, figueiras, amendoeiras, nogueiras, aveleiras, marmeleiros, laranjeiras azedas e limoeiros, estas duas últimas introduzidas pelos árabes.

Quanto aos outros vegetais, há referências de que eram cultivados em quintais, almoinhas e hortas perto da casa ou nos termos do centro urbano, como mostra a Figura 13, uma vez que sendo produtos frágeis, não podiam ser transportados a longas distâncias. Entre eles estão as couves, tanto a comum quanto a couve-flor, berças, favas, feijões e ervas aromáticas, tendo sido estas últimas, também, introduzidas pelos árabes.

Figura 13 - Plantações de gêneros alimentícios próximos às casas na Idade Média.



Fonte: COSMAN 1976, p. 9. 
Os legumes e verduras não eram muito apreciados pelas classes superiores, mas para o povo restava usar muitos alimentos de outra origem que não a animal; brócolos, alfaces, pepinos, rabanetes, cogumelos, cenouras, nabos, aspargos, além de outros vegetais também mencionados, estavam sempre caracterizando a mesa das famílias mais pobres (MARQUES 1974).

Portugal não possuía abundância de pastos, portanto, não poderia ser grande produtor de gados. Mas apesar da quantidade diminuída de animais dedicados ao abate, não há indícios de grandes importações. Além do mais, como já mencionado, os animais de caça completavam a mesa do português abastado, sendo mencionados todos os tipos de animais silvestres como coelhos e lebres, veados, javalis e até ursos (TAVARES 1992).

Das sessenta receitas do livro já mencionado, vinte e seis são receitas com carnes, todas elas muito bem condimentadas com ervas e especiarias, $\mathrm{o}$ que, segundo MARQUES (1974), significa que eram voltadas para as classes mais ricas, que podiam se dar ao luxo de gastar dinheiro em itens tão caros.

No balanço geral tem-se:

- 10 receitas com aves, sendo que destas 4 levam toucinho,

- 3 com carne de porco, ou suas partes, 1 com toucinho,

- 1 com carne e 1 com fígado de carneiro,

- 2 para carne de vaca,

- 1 de coelho com toucinho,

- 1 com lampreia e outra com láparo.

- 8 destas receitas de carnes levam ovos inteiros, sendo que 1 ainda leva mais gema,

- 10 levam apenas carnes e gemas,

- 4 levam apenas ovos inteiros,

- 2 levam apenas gemas. 
- 2 que levam ou carne de carneiro ou de porco e

- 1 receita que leva carne de galinha, carneiro e toucinho misturados.

Como pode-se perceber, todas as carnes pareciam ser apreciadas. Somando-se a estas estavam as de caça, como as perdizes, abetardas, grous, patos bravos, cercetas, garças, maçaricos, fuselos, sisões, galeirões, calhandras, entre outras, e as de criação como galinhas, patos, gansos, pombos, faisões, pavões, rolas e coelhos, como ilustrado na Figura 14.

Figura 14 - Aves domésticas, e de caça, abatidas para alimentação.



Fonte: OLGA'S GALLERY 2001.

Há, contudo, uma ressalva que seja importante destacar, um aspecto ligado mais à história que à própria alimentação. Sabe-se que grande parte da população não sabia ler ou escrever e que, portanto, ao considerar-se estas receitas, tem-se que fazê-lo lembrando que elas podem estar representando 
uma parcela pequena da verdadeira sociedade portuguesa do século $\mathrm{XV}$, provavelmente nobreza.

Com a expansão do Império Romano, alguns dos antigos hábitos trazidos pelos soldados acabaram resistindo ao tempo e às conquistas germânica e muçulmana. Há uma citação que menciona o fato da pesca, e as indústrias a ela ligadas, como a conservação do peixe ou a produção de garum (mencionado anteriormente), já eram antigas nas costas portuguesas, representando uma das grandes exportações da Lusitânia romana (TAVARES 1992). A variedade dos pescados era grande, indo de baleias às sardinhas. As técnicas de pescaria variavam de acordo com o peixe selecionado.

TAVARES (1992) menciona uma referência que aponta na mesa de D. Afonso V, em 1474, variedades de peixes como a azevia, o salmonete e o linguado, mas é provável que o fato se devesse aos gostos pessoais do rei, uma vez que não se pode apontar com segurança as variedades de peixes mais apreciados e consumidos. A sardinha aparece sendo um peixe muito consumido, sendo que as referências à sua exportação são abundantes.

Portugal está localizado no extremo sudoeste da Europa, de frente ao Oceano Atlântico. Tem a forma de um retângulo estendido no sentido meridional com $560 \mathrm{~km}$ de norte a sul e 110 a $200 \mathrm{~km}$ de leste a oeste (NEB 1997). Não é difícil concluir que os peixes e produtos marinhos constituíssem itens importantes na alimentação, sendo considerados como parte dos alimentos básicos, principalmente nas classes menos abastadas (MARQUES 1974). Um dos fatores que certamente contribuiu para essa importância foram as prescrições religiosas, que instituíam jejuns e abstenção de carnes, praticada sessenta e oito dias no ano. Nestes dias, os peixes e mariscos substituíam a carne, e até os queijos, ovos, manteiga, banha, vinho, além dos peixes gordos, que eram proibidos. 
No geral, os peixes mencionados na literatura são: pescada (peixota) sardinha, congros, sáveis, salmonetes e lampreias (estes são os peixes mais freqüentes e presentes em todas as classes sociais), ruivos, pargos, atuns, trutas, solhos, bizugos, cações, rodovalhos, gorazes. Além desses, também, são mencionados baleias e toninhas, mariscos (amêijoa e berbigão), e crustáceos (lagostas e caranguejos). Os mariscos representavam basicamente alimento para as populações ribeirinhas, principalmente no inverno.

Faz-se menção, também, de que eram consumidos peixes de água doce e salgada, de rios e lagos, de outros reinos, frescos, secos, salgados ou fumados, sendo estes mesmos responsáveis por grandes exportações para Castela e Mediterrâneo.

ZURARA (1937) menciona que em sua viagem à Guiné costumavam pescar para comer e que, em certa ilha, encontraram um grande grupo de tartarugas; os pescados, de maneira geral, eram muito apreciados pelos mouros dali. Menciona, ainda, a pesca de lobos marinhos para extração de óleo. Cetáceos, como baleias e golfinho, eram destinados em grande parte à produção de óleos, e rendiam muito dinheiro (TAVARES 1992).

TAVARES (1992) conclui ser possível afirmar, em síntese, que a atividade piscatória foi importante no reino, embora secundária em relação à agricultura. Foi importante e até suficiente para o consumo interno, na forma de pescado fresco, seco, salgado ou fumado, de tal modo que se tornou uma das principais exportações medievais portuguesas; não se deve esquecer que a seus portos chegavam peixes de outras proveniências, entre os quais o arenque, referido no foral de portagem de Lisboa. Este, muitas vezes, era traficado no norte da Europa.

Considerando que não havia frigoríficos e o clima era pouco frio, a secagem e defumação dos peixes possibilitava o seu transporte $e$ armazenamento por longos períodos, tornando esse produto muito 
importante para o abastecimento. Mais tarde, seria um dos principais produtos alimentares embarcados para as viagens transoceânicas.

O vinho, apesar de soar estranho para hoje, representava um gênero importante para a subsistência dos homem da época. Sabe-se que ele fornece cerca de $7 \mathrm{kcal} / \mathrm{g}$, sendo uma importante fonte de energia. Há porém, o outro lado da moeda. Essa calorias são praticamente "vazias" já que o vinho possui quantidades muito pequenas de outros nutrientes.

Cultivadas por toda a parte e associadas a outros produtos, as vinhas ocupavam grande território, sempre ao redor dos centros urbanos. Produziase vinho branco, tinto, vermelho, doce, malvasia, etc. $O$ vinho português era muito apreciado em outros países e por isso acabou sendo um importante produto de exportação, mantendo-se, assim, como um esteio à economia da época.

Não costumavam beber o vinho puro, mas dividido meio a meio, ou como diziam os portugueses da época, terçado: $1 / 3$ de vinho para $2 / 3$ de água (ARNAUT 1986).

Apesar de todos os problemas que podem ter causado, o vinho, e outras bebidas alcoólicas, representavam um alento nos momentos de tristeza ou carestia, pois, sendo um bloqueador do sistema nervoso central, causavam um falsa sensação de bem estar e conforto, que, mais tarde, podia representar sérias conseqüências ao restabelecer-se a consciência da realidade.

Juntamente com os biscoitos de cereal e os peixes salgados, o vinho era oputro importante item embarcado no período das grandes navegações, pois, como pode ser verificado, a quantidade de vinho embarcada era muito grande. 


\section{2 - VIDA E ALIMENTAÇÃO NAS EMBARCAÇÕES PORTUGUESAS DOS SÉCULOS XV E XVI}

As viagens, de modo geral, contribuíam muito para o aumento da variedade de alimentos como no seu preparo. Um exemplo disto foi a viagem de Marco Polo ao Oriente, que ao relatar o que seus olhos haviam presenciado, chocou e despertou a curiosidade de toda uma época. A massa, o macarrão da Europa, foi trazido da China (POLO 1994).

Viajar, entretanto, requer preparativos e provisões, que no caso das embarcações portuguesas, muitas vezes, não eram suficientes.

As condições de vida a bordo de uma embarcação à velas tinha mudado muito pouco até o início da época dos barcos a vapor (BATHE et al. 1967). Os embarcados colocavam suas vidas nas mãos dos capitães, sempre esperando que pudessem chegar ao seu destino. A viagem, por sua vez, era sujeita aos caprichos da natureza que podiam variar de tempestades, ventos fortes e excelentes, até calmarias sem fim que tornavam as viagens um verdadeiro inferno. Vasco da Gama, por exemplo, levou 315 dias para chegar às Índias (FERREIRA 1990).

As condições de higiene eram péssimas. FERREIRA (1990) comenta: "Estas massas humanas amontoavam-se assim nos navios ao lado das cargas, dos abastecimentos, de mistura com os animais vivos que eram transportados na maior parte para consumo rápido ou outros destinos. Ao chegarem os navios aos mares quentes, já os insectos, ratos e baratas proliferavam em abundância e eram responsáveis por destruição de alimentos, apetrechos e por incômodos e contágio de doenças das pessoas a bordo" (p. 138). A Figura 15 mostra uma ilustração de como era o local das refeições. 
Figura 15 - Ilustração do local das refeições a bordo dos navios



Fonte: CAINÉ 2001

Os constantes conflitos a bordo tornavam o ambiente tenso, o que por estas ou outras razões, culminavam em motins e até execuções. A comida era medíocre. Os marinheiros, entretanto, se consideravam muito afortunados quando terminavam seu percurso sem terem morrido de fome ou sede, ou de outras enfermidades, como o escorbuto.

O abastecimento da tripulação e dos eventuais passageiros era uma tarefa difícil e de novo progressos significativos não foram feitos até o século XIX. De modo geral, a comida servida a bordo permaneceu a mesma durante 200 anos. Os utensílios usados na preparação das refeições continuavam os mesmos usados nas cozinha medievais: um caldeirão pendurado ou encaixado sobre uma plataforma limitada de pedra, onde se acendia o fogo.

A alimentação nos navios era constituída por alguns alimentos básicos. FERREIRA (1990) menciona biscoito, favas, arroz, carne salgada, 
peixe seco e salgado, azeite, vinho, água, aguardente e mel. O suprimento de carne se dava pelo transporte de animais ainda vivos (até que durassem). Vegetais frescos e frutas se esgotavam rapidamente, perdendo seu viço e propriedades nutricionais, o que acabou por gerar tantas enfermidades, entre elas o escorbuto.

Quase nada se encontra com relação ao preparo: os horários para cozinhar, como os alimentos eram preparados (especialmente as carnes e grãos), se havia alguém responsável diretamente por esta tarefa, etc., apesar de se saber que cozinhavam a bordo.

MENEZES (1987) menciona, ao longo de seu estudo, que alguns padres, por vezes, se aventuravam a cozinhar alguma coisa, o que sugere não haver um responsável para isto, pelo menos por parte dos passageiros. Outra conclusão que se pode ter é que, talvez, o responsável estivesse doente ou até morto.

Conta BATHE et al. (1967) que para evitar problemas, algumas embarcações européias adotavam um processo de divisão da comida, neste caso, bastante curioso: os tripulantes eram divididos em grupos de mais ou menos 7 homens, enquanto a comida estava sendo preparada. Um representante de cada grupo colocava, dentro do caldeirão, a sua porção de carne, presa por um gancho ou espeto que era marcado. Deste modo, quando a comida estivesse pronta, seria fácil identificar cada porção de carne. Como não havia confiança mútua, após a carne ser colocada no caldeirão, a tampa era firmemente fechada e um "master-at-arms" trancava a mesma para evitar eventuais roubos ou até que outras "coisas" fossem acrescentadas. No horário das refeições o cozinheiro "pescava" os pedaços de carne e os dava aos seus donos de direito.

A secagem e o sal pareciam ser os únicos métodos de conservação mencionados; por isso mesmo, havia grandes quantidades deste último a 
bordo. O suprimento de carnes frescas rapidamente se acabava, pois, o gado e as aves trazidos vivos a bordo eram insuficientes para as longas viagens e, não raras vezes, separados para os doentes.

Em meados do século XVII, os franceses tentaram estabelecer em seus barcos currais de ovelhas e carneiros para melhorar o suprimento de carne fresca. Outra novidade era o que se podia chamar de horta. Vegetais frescos cresciam no convés, se a quantidade de água assim o permitisse.

Quando o tempo era bom, arpões eram usados para a pesca de peixes; nas águas tropicais capturavam tartarugas, que podiam ser mantidas vivas, sem alimento, por até um mês, o que para os marinheiros era uma excelente fonte de alimento (Figura 16).

Figura 16 - Captura de uma tartaruga para alimentação a bordo



Fonte: BOTTING 1980, p. 44 
Toda a comida, carnes salgadas, biscoitos e vegetais, eram armazenados em barris de madeira, porém, as condições higiênicas eram tão ruins que eventualmente propiciavam o desenvolvimento de vermes e parasitas. O capitão Bougainville, certa vez, mencionou que os ratos comiam o equivalente a $1 / 5$ de tudo que a tripulação deveria consumir (BATHE et al. 1967).

Um regulamento para estabelecer o que a tripulação deveria embarcar para comer só foi estabelecida pela França em 1669, ao contrário de Portugal que já em 1505, segundo MENEZES (1987), já tinha em vigor o "Regulamento dos mantimentos". A diferença nas datas parece demonstrar que Portugal apresentava uma característica muito mais voltada para o mar que a França; e não somente ao mar mas às expedições de exploração, com conquistas de novos territórios, fato realizado pela França apenas muitos anos mais tarde.

O regulamento francês previa carnes em geral, carne de vaca ou bacon defumado três vezes por semana, e peixe, ou bacalhau, nos outros dias. Em navios de países católicos esta carne era substituída por queijo nos dias de jejum, o que a tripulação não apreciava. Diariamente, os marujos recebiam uma porção de feijão ou ervilhas, juntamente com o biscoito do navio e vinho diluído em água.

Certamente regras e procedimentos para abastecer os navios portugueses com provisões alimentares para viagens já deviam existir desde muito tempo antes às formalmente estabelecidas. Segundo MENEZES (1987), o $1^{\circ}$ registro data de $01 / 02 / 1317$, onde encontra-se um contrato entre o rei e o almirante Micer Manoel Peçanha, que menciona pão, biscoito e água.

MENEZES (1987) prossegue suas descrições e na seqüência cita mais referências aos mantimentos. $O$ pão começa a se destacar, sendo que em 1416, na lista na Nau de São Cristóvão, aparecem utensílios próprios para amassar e assar pães a bordo, o que já devia ser comum nesta época. 
Provavelmente, o uso de fornos "portáteis" poderia ser adaptado ao uso nas embarcações, como mostra a Figura 17.

Figura 17 - Forno portátil usado durante a Idade Média, provavelmente adaptado para uso em embarcações.



Fonte: COSMAN 1976, p. 66.

Por volta de 1436, a conquista de vários pontos na costa africana exigiu de Portugal o estabelecimento de um armazém para socorrer seus novos territórios. Os suprimentos eram tomados nas várias cidades onde os soldados ou marinheiros passavam. Estas, por sua vez, reclamavam as dívidas deste abastecimento a Lisboa. Entre esses produtos constavam: trigo, cevada, centeio, milho (milhete), biscoitos, pescadas, arraias, cações, sardinha, soãs de carne (dorso), pedaços de carne, vinho, vinagre, sal, água 
entre outros. A Figura 18 mostra o momento de abastecimento dos navios. Existem indicações concisas de navios destinados, nesta época, só para mantimento e reabastecimento, o que atendia as necessidades de conquista de Portugal.

Figura 18 - Ilustração de um navio sendo abastecido no porto antes da partida



Fonte: BATHE et al. 1967, p. 162

Entre 1440 e 1450 foram muitas as expedições ao longo da costa africana, mas de novo poucas são as informações sobre os mantimentos. Ocasionalmente, faz-se referência aos chamados "refrescos", ou seja, fornecimento de víveres (EPO, 1998). Entre esses refrescos citam-se garças, tartarugas e peixes. A ilha da madeira aparece várias vezes como sendo um bom lugar para reabastecimento. ZURARA (1937) faz menção da ordem do rei neste sentido. 
Quando paravam em lugar próprio para pescarias, e conseguiam bons resultados, parte era consumida na hora e o que sobrava era salgado e armazenado. Isso justificaria tantas menções quanto ao transporte de sal em grandes quantidades. Os peixes eventualmente poderiam acabar, mas não o sal que os conservava.

Em 1451, por ocasião do transporte de D. Leonor, irmã de D. Afonso, para seu casamento com o Imperador da Alemanha, vê-se o $1^{\circ}$ relato de uma refeição a bordo de uma embarcação portuguesa. Diz-se que o marquês de Valença, Capitão General de Mar e Terra, para evitar os perigos de muitos fogões acesos durante a viagem, estabeleceu horários para comer, assim divididos:

- Marinheiros: ao nascer do sol

- Fidalgos e militares: antes do meio dia.

- A imperatriz, sua família e os embaixadores: ao meio dia.

Nestas refeições aparecem "conservas", pão torrado e peixes pequenos salgados. Conta o mesmo documento que uma caravela foi enviada para buscar carnes, pão fresco, água e frutas para os viajantes.

Em 1452, tem-se na $1^{\text {a }}$ lista de mantimentos, destinada à carreira de Veneza, composta de 4 galés. Para cada galé iriam:

- 500 pães alvos de real

- 2 tonéis de vinho

- 4 vacas

- 2 gigas grandes de frutas (não cita quais são)

- 100 quintais de biscoito (ou 6 toneladas)

O problema é que não se sabe o número de pessoas. Cada galé podia ter de 2 a 3 homens por remo e de 25 a 30 remos de cada lado, o que somaria de 100 a 180 homens por galé, uma diferença muito grande. 
A experiência de estar indo cada vez mais longe para exploração ocasionou, por parte das autoridades portuguesas, uma capacidade de estimar os alimentos necessários às viagens. Em 1488 encontra-se uma previsão de biscoitos como sendo 28 libras/mês/homem, ou 1 arroba e 13 libras. Em 1490, D. João II manda fornecer 233 quintais de biscoito para mantimento de 64 homens durante os 10 meses de viagem até o Congo.

1 quintal eqüivale a 4 arrobas (SEGUIER 1931) ou aproximadamente $60 \mathrm{~kg}$ (EPO 1998). Desta maneira pode-se calcular genericamente que cada indivíduo teria direito a $730 \mathrm{~g}$ de biscoito por dia, o que na prática, nem sempre era possível, considerando-se nessas viagens de longa duração os problemas com o tempo e a perda pelos vermes, insetos e ratos.

Portugal, por esta época, já sabia que o comércio de especiarias orientais era uma grande fonte de lucro. Segundo ROSENGARTEN JR (1973), os europeus obtinham as valiosas especiarias para dar sabor às suas comidas desinteressantes e, muitas vezes, parcialmente decompostas, além de prover fragrância para mascarar odores desagradáveis. Elas traziam novidade ao estilo da mesa medieval, de várias formas, realçando e variando o sabor dos alimentos já consumidos, proporcionando-lhes uma sensação de novidade. Podiam, ainda, mascarar o sabor desagradável de alimentos não tão frescos ou até mesmo em estado de decomposição, como pode ser visto em livros e artigos que tratam das viagens marítimas transoceânicas (BATHE et al. 1967; ROSENGARTEN JR 1973; RAMOS 1997). E se eles, portugueses, não poderiam chegar por terra, então, chegariam por mar.

Neste ponto, a primeira viagem de Vasco da Gama, em 1497, foi um marco de muitas conquistas, mas também, muitas perdas. Sua narrativa apenas menciona que havia um barco especialmente destinado ao transporte de mantimentos. Infelizmente a menção dos víveres é pequena. Os alimentos citados por Duarte Pacheco foram pão, vinho, farinhas, carnes e legumes 
(sem mencionar quais). Mário Domingues acrescenta biscoitos, feijão, azeite, carnes secas e salmouras (MENEZES 1987). Uma viagem desta natureza e duração também ofereceu a oportunidade de se conhecer as possibilidades de reabastecimento ao longo do caminho. Narra este documento que em alguns portos foram negociados carneiros, lenha, lagosta e um baleote. Também recebiam dos habitantes locais presentes como laranjas doces, cana de açúcar e carneiros.

Nem sempre a tentativa de negociar mantimentos era bem sucedida. Em alguns locais havia necessidade de batalha, o que enfraquecia ainda mais a tripulação, que ao longo da viagem já sofria, horrivelmente, com o escorbuto.

Apesar de todas as dificuldades, a viagem foi bem sucedida quanto ao seu objetivo principal: chegaram às Índias e compraram mercadorias. O lucro desta expedição foi de $6.000 \%$ sobre o que foi investido (CAMPOS 1983); grande, também, foi o número dos mortos; dos 170 apenas 44 sobreviveram (FRANCO 1986).

Certamente, devido a este grande sucesso de Vasco da Gama em sua expedição, os comerciantes portugueses devem ter considerado como investimento de grande lucratividade as viagens para às Índias. A grande quantidade de navios, caravelas e naus que partiam de Portugal para lá, prova isso. Dos anos de 1500 a 1505 foram 87 embarcações, sendo: 58 naus, 7 caravelas, 18 navios, todos destinados às Índias e à Costa Oriental da África.

É de se supor que com todas essas viagens ao longo da costa africana surgisse a necessidade de se estabelecer condições para que todas essas expedições se realizassem. Em outras palavras, era necessário o estabelecimento de "portos amigos" que possibilitassem o comércio de víveres necessários às viagens, locais de atracamento para descanso da tripulação, obtenção de água fresca, etc. 
Todo esse movimento, certamente, implicaria na organização do abastecimento que, mais tarde, culminou na fundação de um armazém para estocar alimentos e outros gêneros, a chamada Casa da Mina, mais tarde Casa da Índia.

Talvez, devido a toda essa organização, é que no ano de 1505 aparece a primeira "Regra dos mantimentos", no regimento do Capitão Mor D. Francisco de Almeida, como anteriormente mencionado. Deste documento foram extraídas as informações que se seguem. Em observação, MENEZES (1987) diz que só extraiu as informações que diziam respeito ao estudo em questão. Isso explica a numeração não seqüencial.

3 - Regra dos mantimentos: basicamente orienta que nas embarcações haja um homem responsável pelo controle dos mantimentos. Este deveria, segundo ordem do capitão, fazer o balanço do que foi gasto durante um mês. Assim o planejamento de onde seria o melhor lugar para abastecer, seria mais fácil e seguro.

4 - Chave dos "payoes": deveria haver um despenseiro [talvez o mesmo] que possuísse a chave da despensa. Esta só deveria ser usada com autorização do capitão. No caso da expedição de Cabral esse homem era Afonso Furtado, Ele era responsável pela distribuição de todos os alimentos de bordo.

5 - "Comcerto" do vinho dos marinheiros: era recomendado que a distribuição da porção diária de vinho fosse feita logo pela manhã, para que cada um fizesse uso de sua parte conforme lhe parecesse melhor.

8 - Água e lenha: Deveriam renovar os estoques de água e pegar mais lenha na "Ylha da Cruz". Há uma recomendação bastante enfática para não perderem tempo neste lugar e seguirem logo viagem (mais para frente encontram-se outros documentos que relatam a diferença acentuada na saúde dos marinheiros que chegavam, às vezes, com apenas 2 semanas de 
antecedência em relação a outros navios; o número de mortos também era bem menor).

63 - Do abastecimento das fortalezas e do depósito de seis meses: Deveria haver uma atenção especial ao estoque das fortalezas, de modo que pudessem sempre estar abastecidas para um período de seis meses e, assim, atender às necessidades dos navios que por ela se abastecessem.

75 - "Roll dos mantimentos": havia um rol de mantimentos já pré estabelecidos que deveriam ser embarcados.

É interessante notar as citações do milho e do arroz como itens importantes no abastecimento local e das naus. MENEZES (1987) destaca que estes poderiam ser oriundos dos ataques aos navios mouros, o que mantinha a aprimazia sobre os mares recém conquistados.

Pela ausência desse tipo de informações sobre a Carreira ao Brasil, é possível supor que os conhecimentos acumulados ao longo da exploração da Costa Africana e Índias traria à Carreira do Brasil as mesmas contribuições e procedimentos, já que os próprios marinheiros assim eram escolhidos, como na expedição liderada por Pedro Álvares Cabral, a que descobriu o Brasil.

Esta expedição saiu do porto no rio Tejo, na praia do Restelo, em Lisboa, no dia 9 de março de 1500, com 10 naus (cerca de 500 toneladas cada) e três caravelas (TERRA NETWORKS 2000).

A tripulação era composta de aproximadamente 1.500 homens, entre os quais 1.200 homens de armas, pilotos portugueses, árabes e indianos, intérpretes, degredados, marujos, grumetes, além de oito frades e oito clérigos franciscanos. Dentre os tripulantes destacavam-se Bartolomeu Dias (o primeiro a dobrar o Cabo das Tormentas), seu irmão Diogo (escrivão de armada de Vasco da Gama), Nicolau Coelho (um dos pilotos de Gama e 
personagem dos Lusíadas), Duarte Pacheco (autor do célebre guia de navegação Esmeraldo de Situ Orbe).

O itinerário de ida foi Ilhas Canárias (14/3/1500), Cabo Verde (22/3), Porto Seguro (22/4), Cabo das Tormentas (24/5), Sofala, em Moçambique (16/6), Melinde, no Quênia (6/7), Goa, Índia (22/8), Calicute, Índia (13/9). Na volta Cananor, Índia (16/1/1501), Moçambique (12/02), Cabo das Tormentas (19/04), Cabo Verde (15/07), chegando em Lisboa no dia 23 de julho de 1501, como mostra o mapa, na Figura 19.

Figura 19 - Mapa do itinerário de Cabral em sua expedição de 1500.



Fonte: TERRA NETWORKS 2000.

O saldo da viagem foram 500 dias de viagens em alto mar, seis navios restantes e cerca de 500 sobreviventes apenas. Porém, um lucro de $200 \%$ aos seus financiadores (CAMPOS 1983). 
Infelizmente, não foram encontrados nos relatórios desta viagem muitas informações consistentes sobre os mantimentos de bordo. Sabe-se que eram acompanhados por navetas de mantimentos, mas não se sabe exatamente seu conteúdo. Mário Domingues relata, por exemplo, que ao entrarem em contato com os índios brasileiros foram oferecidos pão, pescado cozido, confeitos, fartéis, mel e figos passados. Caminha menciona que os índios se assustaram com as galinhas quando as viram (NPILL 2001).

É de se supor que esta expedição seguisse às mesmas normas de abastecimento das outras. MENEZES (1987) cita um documento, não datado, que descreveria quantitativamente os alimentos embarcados em uma caravela. A quantidade descrita deveria suprir a necessidade de 31 homens em um mês, como apresentado na Tabela 1.

Tabela 1 - Cálculo aproximado da ração alimentar diária em caravelas do século XVI, segundo MENEZES (1987) e BUENO (1998).

\begin{tabular}{l|rrr}
\hline \multirow{2}{*}{ Alimento } & $\begin{array}{r}\text { Quantidade } \\
\text { embarcada* }\end{array}$ & & \multicolumn{2}{c}{ Ração diária aproximada para cada homem } \\
\cline { 2 - 4 } & & Segundo Menezes & Segundo Bueno \\
\hline Biscoito & $707 \mathrm{~kg}$ & $760 \mathrm{~g}$ & $400 \mathrm{~g}$ \\
Carne & $331 \mathrm{~kg}$ & $355 \mathrm{~g}$ & $500 \mathrm{~g}$ \\
Vinho & $1460 \mathrm{l}$ & $1,5 \mathrm{l}$ & 1,41 \\
Azeite & $31 \mathrm{l}$ & $33 \mathrm{ml}(2)$ & - \\
Vinagre & $62 \mathrm{l}$ & $66 \mathrm{ml}(3)$ & - \\
Pescadas & 77 unid. (1) & $25 \mathrm{~g}$ & $1,4 \mathrm{l}$ \\
Água & - & - & - \\
\hline
\end{tabular}

* Segundo documento não datado de MENEZES (1987).

(-) sem dados, (1) com cerca de $300 \mathrm{~g}$ de parte comestível por peixe fresco., (2) o que eqüivale a 3 colheres de sopa, (3) ou quase meio copo. 
MENEZES (1987) relembra que a distribuição do biscoito, do vinho e da água deveriam ser diárias. BUENO (1998), entretanto, dá uma outra versão aos acontecimentos diários, relacionados à alimentação.

Segundo BUENO (1998), a tripulação recebia rigorosamente as mesmas quantidades de alimento: $15 \mathrm{~kg}$ de carne salgada por mês (o que, estranhamente, parece ser excelente), mais cebolas, vinagre e azeite. Nos dias de jejum recebiam arroz, peixe, ou queijo, para substituir a carne. Os capitães tinham um privilégio: podiam transportar animais vivos, como galinhas e ovelhas, para seu consumo pessoal. A Figura 20 dá uma noção de como seria isso.

Figura 20 - Animais a bordo destinados a alimentação.



Fonte: BATHE et al. 1967, p. 169.

Segundo BATHE et al. (1967), pode-se verificar que a quantidade de vinagre embarcado era muito grande. A resposta, segundo ele, talvez esteja na crença de que o vinagre misturado à água, além de matar a sede, era bom para prevenir e combater o escorbuto. E quanto a isso BUENO (1998), também, conclui que o vinagre não era usado apenas nas refeições, servia 
para limpar a sujeira das partes interiores do navio. Sabe-se hoje, que o ácido acético, contido no vinagre, é um ótimo agente sanitizante, sendo recomendado para a higienização de frutas e hortaliças em âmbito doméstico.

Não é de se espantar que grande parte da tripulação e passageiros viesse a adoecer. As condições de acomodações normalmente forçavam os homens a ficarem expostos ao tempo. Quando podiam se esconder em algum abrigo, faziam daquele lugar seu dormitório, como mostra a Figura 21. Essa situação levava grande parte da tripulação, especialmente os grumetes, a ficar doente. Esses, por sua vez, podiam ter dois destinos: ficar a bordo ou ser tratado em um hospital já estabelecido nos territórios conquistados.

Figura 21 - Ilustração de um abrigo usado pela tripulação para se proteger do tempo.



Fonte: CAINÉ 2001 
Os doentes tinham um tratamento que poderia ser considerado até "especial". Por volta de 1506 a alimentação destinada aos doentes confinados a esses hospitais era a mesma praticada em Portugal, como se vê: "... onde, fora de costume da terra, todo los doentes comem pam [pão] de trigo, galinhas, ouvos [ovos], lentilhas, bredas, passarinhos quando se acham e azeite de vossos regnos [reinos]...". Há outra referência, de 1510, onde consta uma ordem de se dar aos doentes quanto vinho fosse necessário. Mais tarde, houve recomendação de que se adquirisse os mantimentos localmente. Entre esses são citados: azeite, mel, "acuqre" [açúcar], manteiga, arroz, vinagre e lentilhas (MENEZES 1987).

Quanto ao tratamento dos doentes a bordo, MENEZES (1987) destaca que nas cartas dos padres faz-se menção a uma "despensa para os enfermos", mas que, mesmo após muita leitura, não conseguiu encontrar algo que provasse sua existência, a não ser o relato de Martim Afonso de Castro, em dezembro de 1565. Neste, ele critica os maus capitães que fazem uso pessoal das provisões enviadas aos doentes: “...porquanto pouca migiricordia e piadade se husa com os doemtes, e pela pouca comta que se tem com elles, porque tudo o que V.A. manda dar vay entregue ao capitão e despenseiro, e, quamdo lho pedem para hos doemtes dizem que tudo esta podre, e que o comerão os ratos, e parece que esta sem razão, pois V.A. manda em cada não hum capellão, que deste se deve comfiar a butica e todallas cousas de doemtes..." (p. 72).

Por volta de 1540, a própria instalação em terra dos homens de armas (como eram chamados os soldados) era precária, especialmente quando envolvidos em combates sangrentos em nome da Coroa portuguesa, que declarava conquistados aqueles territórios. Houve época que a pobreza era tão grande (assim como o número de homens aleijados pelas batalhas enfrentadas), que alguns capitães se revoltavam contra a coroa, por vivenciar que não havia o que comer e que os homens morriam à mingua por 
necessidades. Já não havia o mesmo cuidado de antes com a alimentação e reabastecimento dos homens longinquamente instalados. Só por volta de 1617 é que se promovem medidas eficazes para remediar esta situação.

Se pouco se sabe sobre como era o abastecimento das embarcações a serviços do rei e das regras relativas aos marinheiros e tripulantes dos navios, muito menos quanto ao que comiam os eventuais passageiros, como os padres, e até mesmo os soldados. Segundo MENEZES (1987), não há documentos que comprovem haver regras específicas quanto a este tipo de abastecimento.

Pelos relatos pode-se deduzir que parte dos mantimentos embarcados eram destinados a estes indivíduos, porém, é interessante notar algumas descrições de que muitos deles traziam consigo o que podiam, em prol de seu próprio abastecimento. MENEZES (1987) diz: "De depoimentos recolhidos de outras cartas [por volta de 1566], diz-nos que os Padres iam pela nau e realizavam peditórios a favor dos doentes, recebendo caixas de marmelada, barris de conserva, galinhas, biscoitos alvo, passas e dinheiro. $\mathrm{E}$ quando os doentes eram muitos se não encontrava já quem quisesse vender uma galinha, apesar do seu preço ir aos 500 maravedis" (cada maravedi valia de 400 a 500 réis da época). Em outro documento, de 1564, encontra-se o depoimento de outro padre que acrescenta o fato de que "tendo faltado pão a bordo, foi com a provisão dos Padres e Irmãos que se supriu a falta, quer para doentes como para sãos, a ponto de sobejar biscoito. E que outros, por esmola, davam pão branco. Do dito se infere que, nem a farinha dos padres, nem a dos 'outros' era da regra da nau, ou dizendo de outro modo, do paiol de El-Rei" (p. 81 e 82). E se a regra de distribuição de víveres fosse igual para todos, quem eram aqueles que estavam necessitados? Passageiros, soldados ou os próprios marinheiros? 
Sobre este assunto MENEZES (1987) conclui: "Não desejo adiantar conclusões, tanto mais que poderá haver, claro está, diversa interpretação para estes documentos. Mas tudo leva a crer que a regra não era igual, e ater sido igual, talvez não fosse igualmente distribuída. Enfim, segredos de negócio sempre houve" (p. 82).

Dos mantimentos, anteriormente mencionados e destinados ao abastecimento das embarcações, o biscoito aparece como o mais importante. Infelizmente, porém, não há referência que se preste a descrevê-lo. MARQUES (1974) apenas menciona que a farinha de trigo também destinava-se a cozer biscoitos para os exércitos ou armadas. Sabe-se de seu ingrediente principal, mas não sabe quais seriam dos demais. É possível deduzir que deveria ser bastante seco e duro, já que destinava-se a períodos longos de armazenamento. Um biscoito pode ser descrito como sendo uma "massa de farinha ou fécula, ovos e, às vezes, açúcar, que é bem cozida ao forno" (EPO 1998). BUENO (1998), entretanto, diz que este biscoito era "duro e salgado" (p. 41).

No século III a. C. os romanos já fabricavam uma espécie de pão, porém, não fermentado. Sua descrição talvez explique o processo usado pelos portugueses no fabrico dos biscoitos: "Coloca-se a farinha numa tábua lisa e joga água quente por cima. Mistura então a água e a farinha, amassando-a com uma mão nada fraca e, quando a pasta líquida adquire consistência, polvilha os pedaços de sal e depois afina a pasta amassada entendendo-se sob as palmas e dando-lhes a forma circular, onde traça marcas de quadrados de dimensões iguais" (ROBERT 1995, p. 133). Por não levarem fermento encorporavam pouquíssima quantidade de água em si, apresentavam-se, por isso mesmo, próprios para consumo mesmo depois de muito tempo. 
Um problema, talvez muito mais sério e que certamente amedrontava até os marinheiros mais experientes, era a questão da água. Esta deveria ser embarcada em pipas ou barris. MENEZES (1987), mencionando Bartolomeu Dias, descreve de modo geral estes barris eram de madeira, forrados de barro e protegidos com resistente arqueação de metal. A Figura 22 mostra como eram armazenados esses barris, por volta do século XVII.

Figura 22 - Barris armazenados nos navios



Fonte: BATHE et al. 1967, p. 79

Os problemas relacionados à água, porém, não se limitavam ao seu armazenamento. Outros fatores como a duração da viagem, possibilidade de aguada em terra estrangeira, bem como as tempestades e calmarias que ora destruíam os barris, derramando seu conteúdo, ora tornando a viagem tão longa que os estoques simplesmente acabavam, eram as maiores 
preocupações. Muitos homens perderam suas vidas por conta destas questões.

Em um de seus relatos, Gaspar Correia narra uma viagem em 1517, onde quatrocentos homens morreram: “...em que acharão grandes calmarias do vento e grandes quenturas do sol, que ardião os corpos da gente, o que causava grande sede, e 'armada hia falta d'agoa. Com que começou a crescer o mal da sede em tal maneyra que a gente começou a adoecer e morrer à sede...qual padecimento matou quatrocentos homens..."(MENEZES 1987, p. $85)$.

E como se tudo isso não fosse suficiente, a transmissão de certas doenças pela água completava o quadro de total desespero que se encontraram algumas embarcações.

Para concluir pode-se dizer que a despeito de toda a organização e regras para abastecimento, o mesmo não foi bem sucedido. A narração de episódios onde a falta de gêneros aparece é bastante grande. Não foram raras as vezes que o abastecimento ocorria de modo incompleto ou mesmo era impossibilitado pela total falta de mantimentos nas fortalezas, ou pela presença de inimigos. É claro, que apesar de poucas vezes mencionado, segundo MENEZES (1987), a deterioração dos víveres embarcados era bastante comum, devido às tempestades que enchiam o navio com água da chuva e do mar, além dos fatores climáticos como o calor e a umidade, sem mencionar o fato da má preparação das conservas a serem embarcadas.

Contudo, é fácil entender que pela maior proximidade com a Europa, o caminho para a colônia na América era consideravelmente melhor que para as Índias. Quando os capitães eram experientes para zarpar na melhor época do ano, sem atrasos, a viagem era bem mais tranqüila. A própria viagem de Cabral prova isso, pois, saindo de Lisboa no dia 09 de Março, chegaram em 
Porto Seguro em 22 de Abril, o que totalizam 44 dias de viagem, além da presença de animais vivos, como confirmam as narrações da viagem.

Por fim, eram esses homens, marcados por lembranças de dias difíceis, que se encaminhavam para habitar a nova colônia. 
3 - ENTRECRUZAMENTO DE RAÇAS, CULTURAS, E EXPERIÊNCIAS ALIMENTARES NA AMÉRICA PORTUGUESA

\section{1 - O BRANCO}

Antes do período marcado pelas grandes navegações, Portugal gozava de uma alimentação relativamente variada e suficiente em quantidades para manter sua população, não fossem os intempéries da natureza ou catástrofes naturais. Por outro lado é difícil saber se isso é verdadeiro, já que os autores colocam toda a população em uma grande pacote, sem distinguir os que moravam nas montanhas dos que moravam no litoral.

Pela grande variedade de alimentos citados, é difícil fazer uma análise da alimentação portuguesa quanto aos seus aspectos nutricionais. Sabe-se o que poderia haver disponível, mas não se sabe o que efetivamente consumiam. Ao olhar-se, por exemplo, os alimentos disponíveis, sejam eles de qualquer natureza, pode-se concluir que, quanto à variedade, eram satisfatórios a uma alimentação equilibrada, já que tinham alimentos de todos os grupos:

- Cereais, pães e massas: trigo, centeio, cevada, aveia, milhete e pães destes cereais.

- Verduras e legumes: couves, tanto a comum quanto a couve-flor, berças, favas, feijões e ervas aromáticas, brócolos, alfaces, pepinos, rabanetes, cogumelos, cenouras, nabos, aspargos.

- Frutas: maçã, pêra, ameixa, cereja, pêssego, figo, amêndoa, nozes, avelãs, marmelo, laranjas azedas e limões.

- Laticínios: Leite, queijos variados e manteiga. 
- Carnes: gamo, zebro, cervo, corço, lebre, veados, javalis.

- Aves: perdiz, abetarda, grou, pato bravo, cerceta, garça, maçarico, fuselo, sisão, galeirão, calhandra, galinha, pato, gansos, pombo, faisão, pavão, rolas.

- Nozes: nozes, castanhas, amêndoas e bolotas.

- Peixes e produtos marinhos: pescada (peixota) sardinha, congros, sáveis, salmonetes e lampreias, ruivos, pargos, atuns, trutas, solhos, bizugos, cações, rodovalhos, gorazes, baleias e toninhas, mariscos (amêijoa e berbigão), e crustáceos (lagostas e caranguejos).

- Outros: Banhas animais e mel.

Mas, pelo final do século $\mathrm{XV}$, sem exatamente se saber quando isso realmente começou, como comenta FREYRE (1963), a qualidade da alimentação em Portugal já estava ruim. Havia uma situação de miséria que resultava do abandono da agricultura, sacrificada pelas aventuras comerciais e ultramarinas. A "indústria da navegação", que dava muito mais lucro que qualquer outra, passou a recrutar quase que toda mão de obra disponível, ao longo de todos os anos em que foi operante. BUENO (1998) aponta que só na expedição de Cabral, que descobriu o Brasil, havia cerca de $2,5 \%$ da população de Lisboa.

Este despovoamento foi, mais tarde, descrito como uma "sangria" por D. Luís da CUNHA (1976), no reinado de D. José. Esta crescente falta de gente era devida a três situações diferentes: primeiramente pela entrada de homens e mulheres aos conventos, o que impedia (teoricamente) o crescimento vegetativo, depois, pela Inquisição, que prendia e matava muitos indivíduos, e por último, a saída de homens para as Índias e Brasil; além disso o tratado com Inglaterra que trocava vinho por tecidos, trouxe um empobrecimento da produção, já que, mais tarde, substituiu muitas lavouras 
de produtos para abastecimento local por vinhas. Portugal passava por uma fase em que os itens que davam mais lucros substituíam o trabalho básico para a subsistência.

Havia, também, a situação de grande indolência e preguiça, devido ao grande número de escravos, estes sim responsáveis por todo o trabalho desenvolvido em Portugal. Segundo a observação de Clenardo, mencionado por FREYRE (1963), Portugal tinha "este brilho de vestuário à custa da verdadeira indigência na alimentação" (p. 291), quando se referia à nobreza.

Somados a isso, ainda, estavam os muitos dias de jejuns compulsórios, 68 dias no total, determinados pela Igreja, (que, consciente ou inconscientemente, regulava o consumo de alimentos disponíveis).

Os homens que aqui chegavam para fixar residência não eram, na sua maioria, indivíduos da classe abastada - com exceção dos padres e demais religiosos que tinham outros interesses - e sim aventureiros, ou degredados, muitas vezes aqui radicados por falta de opção. Eram homens rudes, essencialmente plebeus, acostumados às dificuldades e, muitas vezes, à fome.

O colonizador português, portanto, foge ao estereótipo de grande homem branco, forte e saudável. Como FREYRE (1963) mesmo menciona, "o Brasil foi colonizado por homens mal nutridos. Há relatos de que o consumo mensal médio de carne era de 1,5 kg!" (p. 287), o que eqüivale a 50 gramas de carne por dia. Em uma dieta balanceada esse valor deveria ser 6 vezes maior, para um homem adulto, em um dia (FNB 1980).

Se em Portugal as condições de vida, nesta época, já eram precárias, piores eram nas embarcações. FERREIRA (1990) comenta: “...eram recrutados os marinheiros e soldados e arrebanhados, às centenas, os vadios e ladrões que enxameavam Lisboa, tudo embarcado sem exame de saúde e sem 
preocupação das doenças que pudessem ter. A Câmara de Lisboa passou a pedir insistentemente ao Rei que em cada nova armada para o Brasil ou Índia fossem levados de Lisboa os 'sem amo', ladrões, criminosos, vadios, pedintes que não tinham casa nem trabalhavam, dormiam nos vãos das portas e arcadas e usavam de todos os processos para viverem à custa da nobreza, clero, comerciantes e da população trabalhadora ou dos que iam adquirindo bens e se tornavam abastados..." (p. 138).

Muitos homens embarcados não tinham a menor idéia do que os aguardava. A capacidade de se adaptar rapidamente e superar bravamente as dificuldades podia ser a diferença entre a vida e a morte. Duas condições diferentes, e vividas a bordo das embarcações, comprovam isso: a falta de água e alimentos e a manifestação de enfermidades, principalmente o escorbuto.

Este inimigo invisível e silencioso, impossível de ser combatido, até pelos mais valentes, tinha como manifestações iniciais inflamação e inchaço das gengivas (como mostra a Figura 23), o que levava a um apodrecimento literal e conseqüente queda de todos os dentes. O mau hálito tornava-se insuportável. Apareciam também, conforme avançava o estado carencial, feridas e hemorragias na pele e nas mucosas, inchaços das extremidades e dores nas juntas. Toda essa condição ocasionava fraqueza, anemia e, fatalmente, a morte. Todo esse quadro se dá pela falta de vitamina $\mathrm{C}$ que leva a uma formação defeituosa do colágeno, uma importante proteína para a formação da pele, tendões, ossos e tecido conjuntivo (SABBATINI 1997).

A vitamina $C$ é hidrossolúvel e, portanto, não pode ser armazenada no organismo, já que sua eliminação se dá pela urina. A dieta nas embarcações, como já constatado, era totalmente isenta de qualquer alimento fornecedor de vitamina $C$, como frutas cítricas e vegetais frescos. Não tardavam a aparecer, portanto, os sintomas. 
Fernão Lopes, citado por CAINÉ (2001), dizia: "....a muitos lhes inchavão as gengivas sobre os dentes que não podiam comer e apodreciamlhe de maneyra que não havya quem suportasse ho fedor da boca, e coestes males padecião dores muy grâdes e morrerâ alguns..." [...] "..para o qual não havia remédio..".

Figura 23 - Gengivas inchadas e inflamadas pela presença do escorbuto



Fonte: CAINÉ 2001

O escorbuto ficou para sempre imortalizado nas palavras de CAMÕES (1979), canto V, versos 81 e 82:

"E foi que de doença crua e feia,

A mais que eu nunca vi, desampararam

Muitos a vida, e em terra estranha e alheia

Os osso para sempre sepultaram.

Quem haverá que sem o ver o creia?

Que tão disformemente ali lhe incharam

As gengivas na boca, que crescia

A carne e juntamente apodrecia 
Apodrecia c'um fétido e bruto

Cheiro, que o ar vizinho inficionava.

Não tínhamos ali médico astuto,

Cirurgião sutil menos se achava;

Mas qualquer, neste ofício pouco instruto,

Pela carne já podre assi cortava

Como se fora morta; e bem convinha,

Pois que morto ficava quem a tinha." (p. 211).

RAMOS (1997) aponta, ainda, para outra questão interessante: a escassez de mulheres nas embarcações portuguesas dessa época. Nas viagens para as Índias, que duravam meses, a presença da mulher era vista, até, como danosa à tripulação. A Coroa Portuguesa, por várias vezes, desencorajava as mulheres para acompanharem seus maridos nas viagens à Índia e ao Brasil; mas no que se referia a este último, costumava ser mais complacente (BOXER 1977). Para RAMOS (1997) controlar o apetite sexual por quatro semanas, talvez, fosse mais fácil.

$\mathrm{Na}$ primeira década de 1500, as mulheres, embarcadas em barcos espanhóis, eram, na maioria, ciganas condenadas por assassinato e falsas esposas (geralmente meretrizes), sem contar as que eram levadas clandestinamente. Isso era devido ao fato de que, entre outras coisas, as mulheres brancas eram muito cobiçadas, algumas chegaram a se tornar verdadeiros prêmios (RAMOS 1997).

Não é difícil concluir que as mulheres de famílias nobres e respeitadas dificilmente iam nessas grandes viagens marítimas. Consequentemente, a falta delas na colônia da América, contribuiu para o empobrecimento da alimentação, já que eram as mulheres que cozinhavam nas famílias para cá embarcadas, dada sua posição social não tão privilegiada. 
Após conhecer a difícil vida do português comum, além das condições do transporte marítimo da época, é fácil entender que a "abundância", muito mencionada nas crônicas, é totalmente relativa ao que os homens estavam acostumados. Para aqueles que sobreviviam às adversidades da vida em terra, e às viagens e excursões de tamanho perigo à existência, a vida na colônia deveria realmente parecer um paraíso.

Olhando-se por seus olhos podia-se ver, talvez, as grandes oportunidades de ser nesta colônia o que não podiam ser em Portugal: senhor de muitas terras, dono de muitos escravos (a exemplo dos fidalgos portugueses). Enfim, ser, mesmo que de maneira ilegítima, um membro da aristocracia portuguesa na colônia.

Algumas narrações e descrições de cronistas e viajantes fazem parecer que essa nova terra era praticamente mágica, pois, sem necessidade de ser adubada, como se fazia na Europa, era capaz de produzir de tudo. Já dizia isso Pero Vaz de Caminha apenas quando a avistou (NPILL 2001).

E para ilustrar tal pensamento é interessante citar a narração de Manoel da NÓBREGA (1988). Em uma de suas cartas ele descreveu um ritual indígena, muito estranho aos seus olhos: “...de certos em certos annos vêm uns feiticeiros [...] e chegando o feiticeiro com muita festa ao logar, entra em uma casa escura e pões uma cabaça, que traz em figura humana, em parte mais conveniente para seus enganos, e mudando sua própria voz em a de menino junto da cabaça, lhes diz que não curem de trabalhar, nem vão á roça, que o mantimento por si crescerá, e que nunca lhes faltará que comer, e que por si virá á casa, e que as enxadas irão a cava e as frechas irão ao mato por caça para seu senhor ..." (p. 99). Mágica ou não, sob certo prisma, isso era verdadeiro.

Desta forma, o modo de vida indígena, nômade e pouco preocupado com sua lavoura, uma vez que seus frutos cresciam praticamente sem sua 
ajuda, acabou, possivelmente, por criar no imaginário do europeu aqui fixado que esta fartura e os recursos da terra seriam infinitos, inesgotáveis. $\mathrm{E}$ para completar o quadro, na visão de muitos, como o padre Simão de Vasconcelos, poderia tratar-se do paraíso, e portanto, ser perfeito.

Esses primeiros portugueses que aqui chegavam deixaram-se encantar pelas belas paisagens recheadas de árvores verdes e clima quente e agradável. O que eles perceberiam mais tarde é que estas condições seriam um dos seus principais obstáculos para sua adaptação à colônia. Como uma linda rosa tem seus espinhos, a nova terra também apresentaria os seus.

E assim foi. A vida na colônia era diferente em muitos aspectos. A falta de recursos conhecidos para desenvolver a vida como ela era em Portugal representou uma rude e brusca mudança na vida econômica e social, apesar de CARDIM (1980) dizer que pela presença de muitos artigos já trazidos da metrópole, como animais e plantas, este já era "um novo Portugal" (p. 57). Mesmo os que tinham mais dinheiro acabavam vivendo de forma simples, como mostram estes quadros de uma casa-grande do século XVII (Figura 24), e como seria seu interior (Figura 25).

Muitos produtos podiam ser portugueses, mas não o era a sua durabilidade. Em relação às condições climáticas havia um “...clima irregular, palustre, perturbador do sistema digestivo; clima na sua relação com o solo desfavorável ao homem agrícola e particularmente ao europeu, por não permitir nem a prática de sua lavoura tradicional regulada pelas quatro estações do ano nem a cultura vantajosa daquelas plantas alimentares a que ele estava a muitos séculos habituado" (FREYRE 1963, p. 79). 
Figura 24 - Casa grande de taipa coberta de palha, no século XVII.



Fonte: CLIO HISTÓRIA 2001a.

A falta de conhecimento das particularidades das estações (no hemisfério sul as estações estão trocadas em relação ao norte), levavam enxurrada abaixo gado e gente, além de inundar canaviais e pastos. As formigas e outros insetos devastavam grande parte do que era plantado, sem mencionar as enfermidades, como descrito por FREYRE (1963): “...no homem e nas sementes que ele planta, nas casas que edifica, nos animais que cria para seu uso ou subsistência, nos arquivos e bibliotecas que organiza para sua cultura intelectual, nos produtos úteis ou de beleza que saem de suas mãos - em tudo se metem larvas, vermes, insetos, roendo, esfuracando, corrompendo. Semente, fruta, madeira, papel, carne, músculos, vasos 
linfáticos, intestinos, o branco do olho, os dedos dos pés, tudo fica à mercê de inimigos terríveis..." (p. 81).

Figura 25 - Interior de uma casa colonial.



Fonte: CLIO HISTÓRIA 2001a .

ALGRANTI (1998), afirma "grande parte dos costumes domésticos dos colonos portugueses teve que se moldar à realidade dos trópicos [...]. O mesmo poderia ser estendido às demais áreas de colonização, uma vez que os adventícios necessitam lançar mão dos recursos naturais disponíveis e aprender, por meio de experiências, muitas vezes dolorosas, como viver na Colônia" (p. 119). FERNANDES (1976) comenta que o ponto onde o mundo colonial se distinguia, era o que se opunha e negava o mundo metropolitano" (p. 20).

d O glossário, localizado no fim do trabalho, contém uma biografia de Rugendas: 
NOVAIS (1998) discute as diferenças básicas entre a vida na metrópole e na colônia. Ele diz: "A colônia é vista como um prolongamento, alargamento da metrópole (a mãe pátria), mas é, ao mesmo tempo, a sua negação" (p. 20). Ele segue enumerando várias características absolutamente distintas e que dão a entender, um pouco, qual o rumo tomado pelos "não reinóis" da colônia.

A primeira delas é que na colônia as pessoas chegam e da metrópole elas saem. Esta característica é apontada por ele como uma das mais importantes: chegam pessoas, mas não são todas de Portugal, chegam também os negros. Este crescimento rápido acaba se tornando um obstáculo para a acomodação e adaptação dos indivíduos, que a princípio se acumulam na costa e depois na região das Minas.

Outra característica apontada é a nova forma de relações dentro da intimidade das famílias. O crescimento rápido, anteriormente mencionado, afetava essa relação diretamente, uma vez que impunha a mobilização para outras partes, às vezes, mais inóspitas que as iniciais. $\mathrm{O}$ deslocamento para áreas ainda desocupadas dava à colônia característica totalmente diferente da metrópole: a grande dispersão territorial. Enquanto em Portugal os indivíduos estavam acostumados a dividir espaços, aqui isso se dava exatamente de maneira oposta, num primeiro momento; havia muito espaço e algumas famílias acabavam por ficar em total isolamento, mantendo-se tão afastadas das influências portuguesas que acabavam por desenvolver em suas vidas um novo rumo, à sua própria maneira.

FREYRE (1963) exemplifica isso dizendo que os fidalgos, na intimidade do seu dia a dia andavam apenas com as roupas de baixo e, às vezes, só de ceroulas, o que seria inaceitável em Portugal. Debrete, também, retratou uma cena que ilustra essa condição. Na visão de Debret, o rico da

e O glossário, no final deste trabalho, contém uma biografia de Debret. 
colônia tinha hábitos muitos distintos aos da nobreza portuguesa. Suas posturas e vestimentas denunciam isso, como mostra a Figura 26.

\section{Figura 26 - "Passatempo dos ricos"}

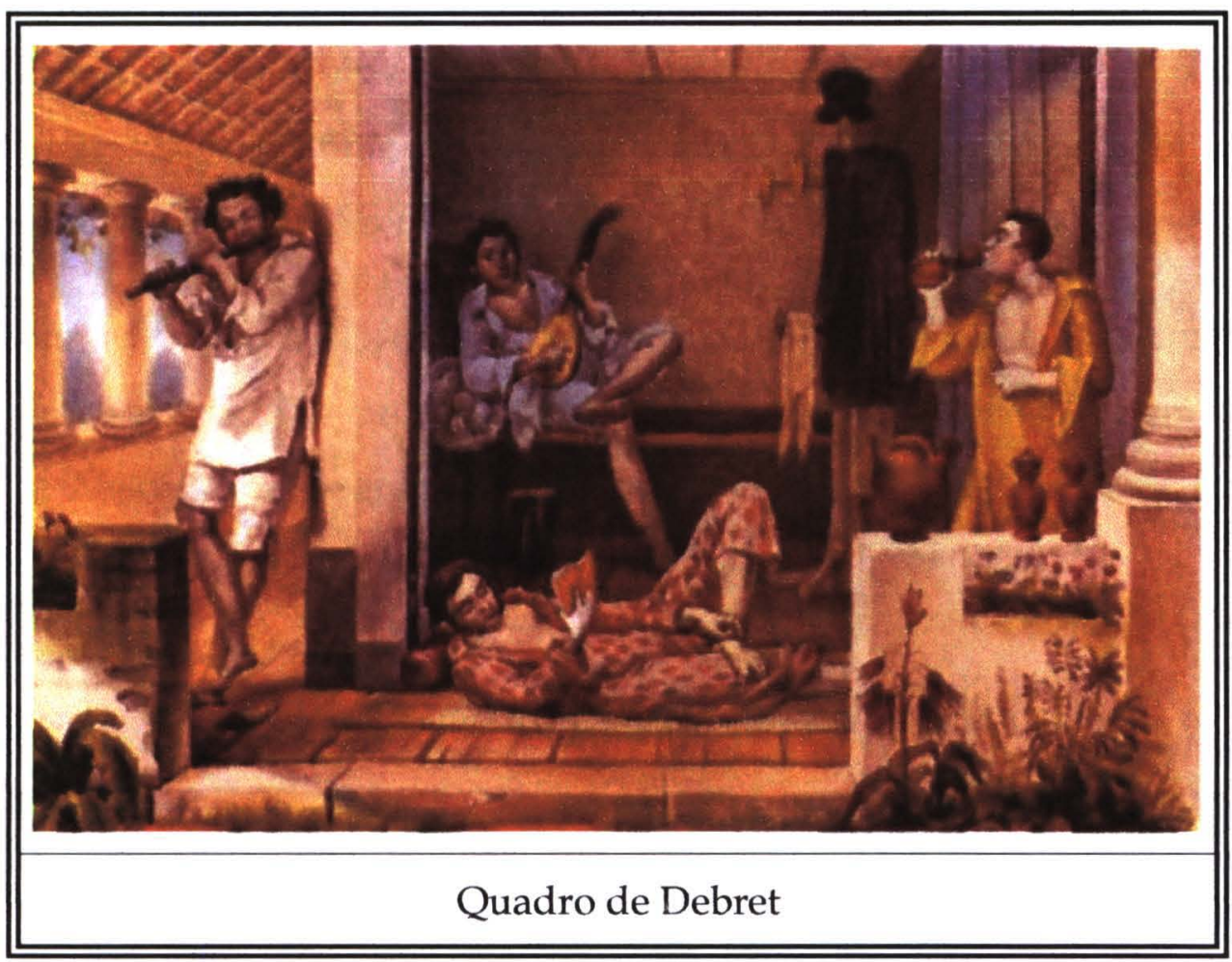

Fonte: EFUSP 1998

Por todas essas características, o quadro geral apresentado foi responsável pela inversão de muitos costumes portugueses, entre eles a troca de papéis do particular e do público. SALVADOR (1982) observa que quanto à aquisição de gêneros alimentícios não se achavam lugares públicos para a compra de alguns itens, como aves e ovos, mas somente nas casas, ao contrário de Portugal. José de Anchieta, também, comenta o fato mencionando que em Pernambuco não havia lugar para abater o gado, de modo que se quisessem comer carne tinham que criar os animais dentro dos colégios (FREYRE 1963). A existência destes pequenos comércios só 
aconteceria no século XVIII, principalmente pela presença dos escravos negros que venderiam diversos produtos.

Quanto aos aspectos mais concretos para a ocupação e colonização da colônia, seriam necessárias várias medidas para tornar os investimentos nesta terra mais rentáveis e lucrativos, além de garantir que nações, como França e Holanda, já infiltradas, fossem banidas, evitando, com isso, que outras seguissem seus exemplos.

Por isso, em 1532, chegava ao litoral de São Vicente, o primeiro engenho de açúcar. Sua produção representaria, com o passar dos anos, a fonte de lucro tão e esperada por parte de Portugal. As Figuras 27 e 28 mostram engenhos de açúcar do século XVII.

Figura 27 - Engenho de açúcar do século XVII.



Fonte: CLIO HISTÓRIA 2001a. 
Figura 28 - Engenho de açúcar do século XVII.



Fonte: CLIO HISTÓRIA 2001a.

O açúcar já era conhecido na Europa nesta época. Fora lá introduzido durante o período das cruzadas. Era muito caro, dada a sua raridade - como a maioria dos produtos de origem oriental - e de distribuição monopolizada por Veneza. Este monopólio foi quebrado no século XV, quando Portugal começou a produzi-lo nas Ilhas da Madeira e nos Açores. Esta bem sucedida experiência acabou por selar o destino da nova colônia que, mais tarde, se valeria principalmente para este fim, já que aqui foram encontradas condições propícias para seu plantio (SCHWARTZ 1988).

Deste modo, grande parte dos esforços aqui concentrados visavam a ocupação e colonização da terra de modo a proteger a nova fonte de 
recursos. MESGRAVIS e PINSKY (2000) chegam a afirmar que "em razão disso, foram empreendidos esforços para dominar a maior extensão possível do território e efetuar sua exploração econômica de maneira mais rentável possível do ponto de vista europeu, já que a colônia era tomada somente como uma extensão da metrópole, subordinada, portanto, aos interesses de Portugal" (p.9).

Assim sendo, os interesses da colônia estavam sujeitos aos da metrópole, com quem, mais tarde, deveriam negociar seus produtos exclusivamente. Segundo SAMARA (1999), as colônias na América deveriam se organizar de modo a suprir as necessidades dos mercados europeus, pela produção de mercadorias de alto valor comercial.

Surgem os primeiros problemas: utilizar europeus para o pesado trabalho da plantação da cana era praticamente impossível. O clima era demasiadamente severo para com estes indivíduos, além do que, por terem sido recentemente "libertos" do sistema de servidão que predominou durante toda a Idade Média, os trabalhadores mais pobres não gostavam da idéia de emigrar para a América como simples trabalhadores. Já eram conhecidas todas as histórias das viagens marítimas, além das dos índios selvagens e canibais que infestavam esta nova terra. Mais dois outros fatores se somavam a estes: a população européia, principalmente em Portugal, era escassa, como já mencionado, e não havia recursos para pagamentos que fossem atraentes a estes indivíduos.

A segunda alternativa para esta questão seria escravizar e usar a mão de obra indígena. Porém, de novo, não foi bem sucedida. O ritmo de vida dos nativos era diferente, mais tranqüilo e sem grandes preocupações. Não estavam acostumados a trabalhar em lavouras mais do que o necessário para sua subsistência. 
Um exemplo bem concreto deste comportamento é o diálogo, registrado por MESGRAVIS e PINSKY (2000), de Léry com um índio. Eles conversam sobre a riqueza que alguns homens na Europa tinham a ponto de poderem comprar de uma só vez todo o carregamento de pau-brasil que eles levavam. $O$ índio muito se surpreendeu e perguntou de quem seriam suas coisas quando viesse a morrer. Léry responde que para seus filhos. Então o índio conclui: "...agora vejo que vós mairs [nome indígena dos franceses pelos tupinambás] sois grandes loucos, pois atravessais o mar e sofreis grandes incômodos, como dizeis quando aqui chegais, e trabalhais tanto para amontoar riquezas para vossos filhos ou para aqueles que vos sobreviverem. Não será a terra que vos nutriu suficiente para alimentá-los também? Temos pais, mães e filhos a quem amamos; mas estamos certos de que depois da nossa morte a terra que nos nutriu também os nutrirá, por isso descansamos sem maiores cuidados..." (p. 42).

Hoje em dia sabe-se, também, que os indivíduos de regiões quentes têm seu metabolismo basal diminuído, o que significa ter necessidade de menos energia para as atividades básicas do organismo - como funcionamento dos rins, coração e outros órgãos involuntários - com relação a um indivíduos de mesmas características de uma região fria (LACAZ 1972). Portanto, ao índio, seu modo de vida era satisfatório. Apesar disso, durante muitos anos, bandeirantes entraram mata a dentro para capturar mais índios para os trabalhos, como mostra este quadro de Henrique Bernardelli (Figura 29).

Alguns índios escravizados preferiam morrer a ter que trabalhar desta maneira. O "não tenho vontade", uma vez dito era definitivo. Outro agravante foi a interferência dos padres jesuítas que protegiam os índios, intervindo diretamente em sua escravização. 
Figura 29 - Captura de índios pelos bandeirantes.



Fonte: CLIO HISTÓRIA 2001a.

A mão de obra teria, portanto, que ser outra. Os negros seriam a próxima escolha dos portugueses

\section{2 - O NEGRO}

O grande sucesso no desenvolvimento das sociedades e culturas de algumas partes da África, como o Egito, na região norte, não pode ser aplicado a todas as suas nações, principalmente as do sul. A África é um continente misterioso, rico em histórias e imensamente vasto para ser caracterizado de forma generalista.

A costa ocidental só começou a ganhar destaque por volta do século $\mathrm{XV}$, quando os portugueses saíram a procura de outro caminho para a 
Índias. Todas essas expedições ao longo da costa propiciaram aos portugueses muitas batalhas com os nativos locais, o que lhes rendeu muito escravos. Estes passaram a ser levados a Portugal para servirem aos comerciantes e senhores.

Com a chegada ao Brasil e as dificuldades para produção de açúcar, principalmente a falta de mão de obra, acabaram por trazer aos engenhos o escravo negro.

Este era por natureza um homem agrícola, acostumado ao trabalho pesado. Mesmo compartilhando com o índio características como a prática da caça e a coleta de alimentos próprios da sua região, pelas próprias características geográficas, essas atividades se diferenciavam.

Por exemplo, o tamanho dos animais: elefantes, rinocerontes, hipopótamos, leões, gorilas, búfalos, avestruzes, etc., são bem maiores que os da fauna sul-americana $\mathrm{O}$ africano deveria conhecer bem os hábitos desses animais para não serem surpreendidos por eles e, também, para caçá-los com sucesso. ORNELLAS (1984) menciona o que acontecia quando caçavam um elefante: “...o trabalho de limpá-lo e prepará-lo tornava-se uma verdadeira orgia. Pé de elefante (que tem gosto de mocotó) é regalo para grandes ocasiões..." (p. 199). Os ovos dos avestruzes, outro grande animal e excelente corredor, eram verdadeiras iguarias, comidos com temperos verdes.

Os africanos criavam cabras, bodes, camelos e galinhas. Destes aproveitavam os ovos e o leite, com o qual, ainda, faziam o queijo e a manteiga. A base de sua alimentação, também, estava no cereal do qual faziam seus pães.

Talvez por sua experiência nos combates ou mesmo pelo contato com a costa africana já obtido a muito tempo, os portugueses perceberam que os negros poderiam ser a solução definitiva para o problema da mão de obra 
nos engenhos da colônia. Iniciaria-se, com isso, a escravidão negra, de modo nunca antes conhecido.

Este, na verdade, é um capítulo à parte na produção do açúcar. Além de representar a solução mais viável para as dificuldades previamente apresentadas quanto à mão de obra, a escravidão representou, também, um fim em si mesma, por propiciar aos que a estimulavam e praticavam, grande fonte de lucro. Este novo "negócio" acabou por gerar uma nova fonte de renda: o tráfico negreiro.

No próprio continente africano a escravidão era relativamente comum. Por viverem em sistemas de tribos, as quais estavam de tempos em tempos envolvidas em guerras, os prisioneiros ou sobreviventes acabavam por se tornar escravos. Porém, a questão de se conseguir grandes lucros por esta prática não era. As guerras perderam seu motivo primordial e passaram a representar, literalmente, o rapto de indivíduos afim de serem escravizados e vendidos. Muitos chefes de tribos, envolvidos com os traficantes, trocavam os escravos por mercadorias como bebidas, panos e enfeites. O escravo era embarcado e vendido pelos comerciantes europeus na América ao lado dos produtos tropicais, como mostram as Figura 30 e 31 . 
Figura 30 - Embarque de escravos nos porões dos navios negreiros.



Fonte: CLIO HISTÓRIA 2001 a.

Figura 31 - Venda de escravos no mercado colonial



Fonte: CLIO HISTÓRIA 2001b 
O escravo negro passou a ter, nesta nova sociedade colonial, duas funções: a de trabalhador e a de mercadoria. Com relação a este último aspecto, sua prática foi tão amplamente difundida que, em 1620, o número de negros nas Américas já superava o de índios. Fage (1969), citado por CAMPOS (1983), dá os números deste comércio, como mostra a Tabela 2.

TABELA 2 - Número de escravos negros desembarcados na Europa e nas Américas entre os séculos XVI e XIX.

\begin{tabular}{l|rrrr}
\hline \multicolumn{1}{c}{ Períodos } & $\begin{array}{c}\text { Nuropa e Ilhas } \\
\text { do Atlântico }\end{array}$ & Américas & Total & $\begin{array}{r}\text { Média } \\
\text { anual }\end{array}$ \\
\cline { 2 - 5 } & 33.500 & 0 & 33.500 & 670 \\
\hline Até 1500 & 116.400 & 125.000 & 241.400 & 2.400 \\
1501 a 1600 & 25.100 & 1.280 .000 & 1.305 .100 & 13.000 \\
1601 a 1700 & 0 & 6.265 .000 & 6.265 .000 & 57.000 \\
1701 a 1810 & 0 & 1.628 .000 & 1.628 .000 & 27.000 \\
Depois de 1810 & 175.000 & 9.298 .000 & 9.473 .000 & \\
\hline Total & 1,85 & 98,15 & 100 & \\
\hline$\%$ do total & & & & \\
\hline
\end{tabular}

Fonte: CAMPOS 1983, p. 37.

Com esses números fica evidente a dimensão que o tráfico negreiro tomou na América, ao longo dos anos, mas principalmente nos séculos XVII, XVIII e XIX.

É imediato concluir que a alimentação do homem negro sofreu um terrível prejuízo durante grande parte do período colonial, especialmente quando eram totalmente dependente de seus senhores para alimentá-lo. A Figura 32 mostra como eram algumas das senzalas da época. Muitos dos problemas de saúde eram devidos às grandes quantidades de indivíduos 
dentro de um mesmo local, o que facilitava a propagação das doenças infecciosas.

Figura 32 - Senzalas do século XVIII.



Fonte: CLIO HISTÓRIA 2001b.

Quando, porém, podiam desenvolver suas pequenas lavouras, FREYRE (1963) diz que sua alimentação era mais saudável até que a de muitos senhores, já que tinham mais abundância de vegetais frescos, sempre presentes em suas hortas e, até, criação de pequenos animais.

\section{3 - O ÍNDIO}

Homens como Hans Staden, alemão que ficou prisioneiro da tribo tupinabá por nove meses e meio, Jean de Lery, viajante francês, Gabriel Soares de Sousa, também viajante, português, e os religiosos Frei Vicente do 
Salvador e Fernão Cardim, dão descrições muito interessante do modo de vida indígena, já que tiveram a oportunidade de conviver com eles. Por esse mesmo motivo, a maioria das informações aqui contidas dizem respeito às essas tribos, que eram mais próximas ao litoral.

Não é intenção deste capítulo esclarecer ou discutir a origem de cada espécie animal ou vegetal, se vinda da África, de Portugal ou de outras partes, mas segundo as descrições dos cronistas e viajantes, estabelecer os alimentos mais comuns.

José de ALENCAR (1993) faz uma descrição romântica do indígena brasileiro, na pessoa de Peri: “Era de alta estatura; tinha as mãos delicadas; a perna ágil e nervosa, ornada com uma axorca de frutos amarelos, apoiava-se sobre um pé pequeno, mas firme no andar e veloz na corrida..."(p.50), como ilustrado na Figura 33.

Figura 33 - Índio brasileiro do século XVII

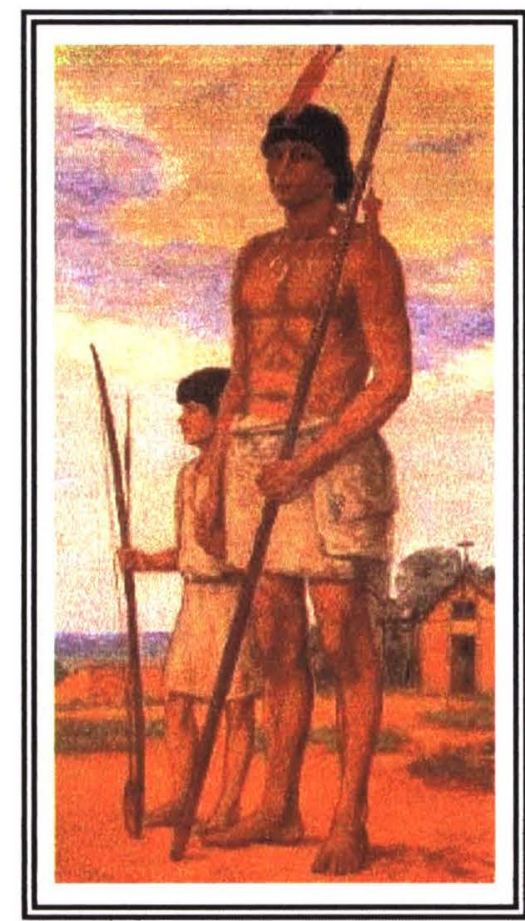

Fonte: MUNDO ANTIGO 2001a 
A vida do indígena brasileiro era simples e atendia satisfatoriamente a todas as suas necessidades. A grande extensão do território intocado permitia e sustentava a condição nômade. Faziam suas casas próximas a locais que tivesse água e lenha, assim como caça e pesca. Uma vez esgotados os recursos daquela terra, partiam para outra.

A caça, a pesca e a coleta eram a base da provisão alimentar. Também plantavam algumas espécies de plantas, entre elas a mandioca, cuja importância será destacada mais adiante.

\subsection{1 - O uso dos recursos naturais: caça, pesca e coleta}

CARDIM (1980) se espanta com o fato de que os índios comiam de tudo: todo gênero de carnes, inclusive as "imundas" como as de cobra, sapos, ratos, e outros bichos semelhantes. Quando saíam a caçar, raramente voltavam de mãos vazias. Conheciam muito bem a região e o hábito dos animais que caçavam, o que os tornava verdadeiros especialistas. Para tal, carregavam apenas o arco e as flechas. Sua pontaria era precisa e poucas vezes erravam. Debret ilustrou uma caçada (Figura 34), provavelmente de aves, já que, pela posição assumida pelos índios, suas flechas iriam para cima.

CARDIM (1980) descreve o que costumavam caçar para comer:

1. Mamíferos:

- Veados - muito apreciados;

- Porco do mato - considerado um dos alimentos mais comuns entre os índios, qualquer que fosse a sua espécie; "todos se comem e são de boa substância";

- Acuti - muito semelhante ao coelho europeu;

- Paca - "...a carne é gostosa, mas muito carregada..."; 
Figura 34 - Uma caçada indígena.

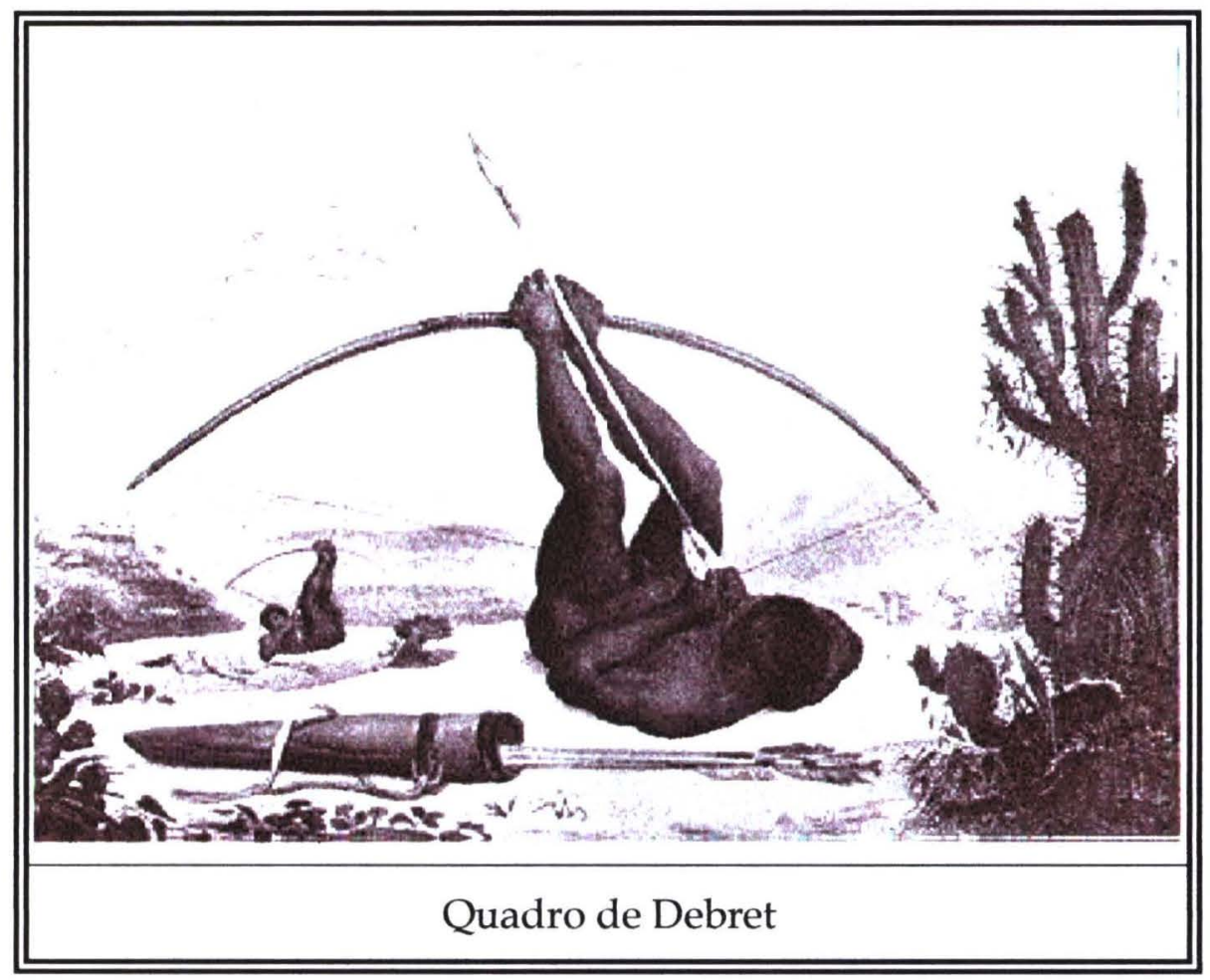

Fonte: MUNDO ANTIGO 2001a.

- Tatu - outra carne muito apreciada que, segundo o cronista, fazia lembrar o gosto de galinha, ou leitão, "muito gostosa";

- Porco espinho - "...são de boa carne e gosto...".

2. Aves:

- Tucano - gostavam de sua carne e apreciavam suas penas para adornos;

- Urú - descritos como muito parecidos às perdizes da Espanha;

- Rolas, melros e pombas que "se parecem muito com as de Portugal". Destes também se comiam os ovos.

Nas caçadas encontravam, também, o mel, que lhes agradava muito. STADEN (1974) não fala do uso do mel, mas diz que os índios enfrentavam 
bravamente as picadas das abelhas (considerando que andavam nus) para conseguir um bom bocado de mel.

Eram, também, extremamente competentes na pesca. Tinham a visão muito aguçada a ponto de perceberem a proximidade do peixe. Para os peixes menores usavam redes, feitas de folhas especiais e longas que desfiadas forneciam longos fios. Os peixes maiores, tanto de mar como de rio, uma vez frechados eram perseguidos pelo índio, excelente nadador, até serem capturados, como mostra a Figura 35.

Figura 35 - Ilustração de índios pescando

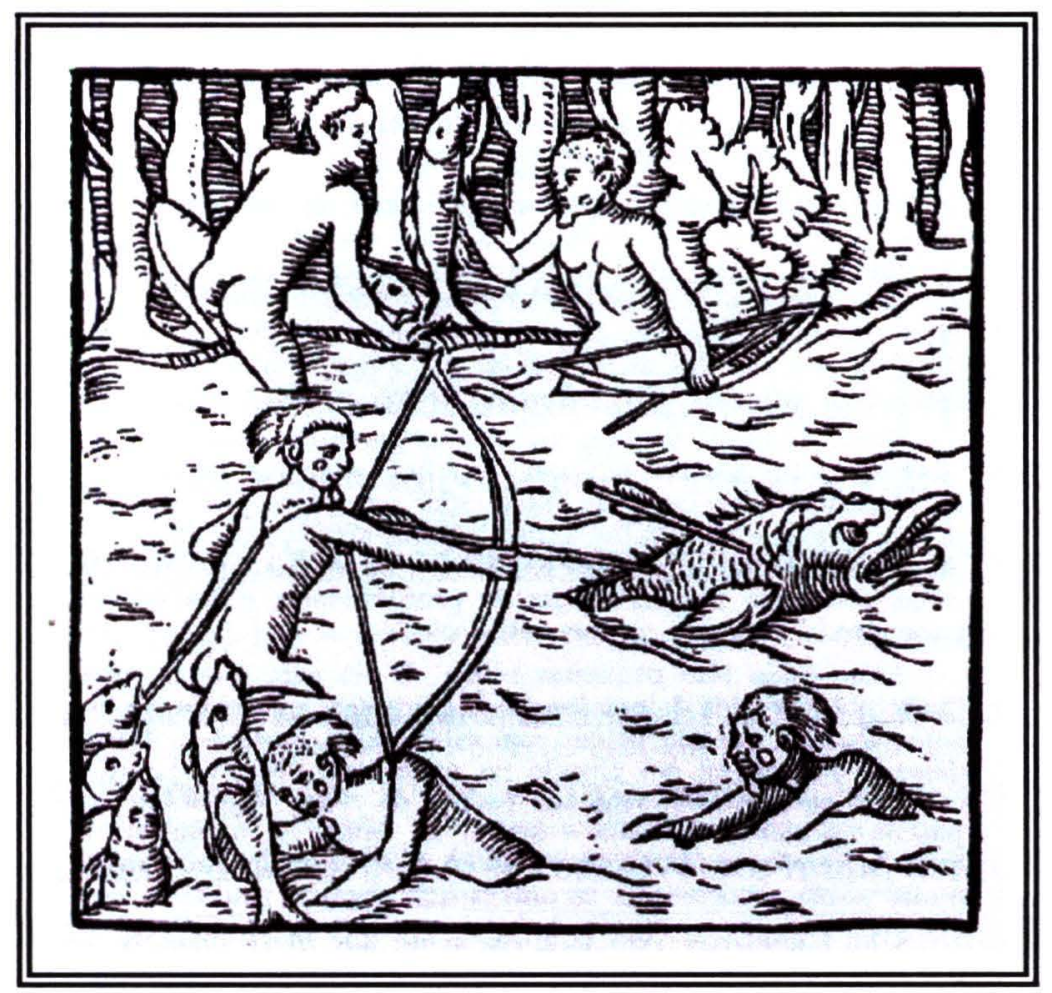

Fonte: STADEN 1974, p. 160

LÉRY (1980) narra que um domingo de manhã viram uma canoa virar; esta vinha com um grande grupo de mais de trinta homens e crianças. Rapidamente saíram num pequeno bote a fim de salvá-los de se afogarem. 
Quando lá chegaram, os índios riam e se divertiam e um deles perguntou por que tinham vindo. Léry respondeu que a salvá-los. "Mas o selvagem replicou: agradecemos a vossa boa vontade, mas pensáveis que por termos caído no mar estávamos em perigo de afogar-nos? Ora, sem tomar pé nem chegar à terra ficaríamos oito dias em cima d'água. Temos muito mais medo de sermos pegados por uma peixe grande que nos puxe para o fundo do que de afogar-nos" (LERY 1980, p. 163). Exagero ou não, certamente eram excelentes nadadores.

A observação de STADEN (1974) é que eram muito solidários. Caso alguém tivesse pescado muito peixe sempre repartia com quem tinha pescado menos. A esse respeito LÉRY(1980) diz que esses índios que conhecera eram muito amigos de pessoas alegres e generosas, sendo eles mesmos desta forma, e alertava: “... posso assegurar aos sovinas, e aos avarentos, aos que comem dentro da gaveta, que não serão bem vindos entre os tupinambás, porquanto detestam tal espécie de gente" (p.166).

As tribos mais interiorizadas migravam, em algumas épocas, ao litoral para a pesca. Era um evento importante e fornecia a estas tribos grande quantidade de alimento. Para não perderem o peixe durante a viagem, já que não costumavam salgá-los - esse costume se consolidou mais tarde com a presença dos europeus - faziam deles farinha. STADEN (1974) descreve esse procedimento: "...torram-nos sobre o fogo, esmagam-nos, fazendo deles farinha, que secam bem afim de que se conserve por muito tempo. Levam-na para casa e comem-na juntamente com a de mandioca [...] também leva uma vasilha mais farinha de peixe do que aí caberiam peixes assados inteiros." (p.159).

Não é de causar estranheza o fato de STADEN (1974) ficar tão surpreso com esse processo. Esses índios nada mais faziam que desidratar os peixes, o que, na sua própria observação, tinha dois objetivos: conservar e 
maximizar o transporte, o que era muito apropriado, já que essas viagens podiam ser bem longas.

Um processo semelhante é o da paçoka, ou paçoca que une diferentes elementos secos que são socados na urupema (FREYRE 1963). Pode ser preparada com outras carnes e farinha de milho, ainda muito consumida no Norte e Nordeste. Pode ser feita, também, com amendoim, sendo esta bem mais conhecida no Sudeste.

Olhando pelo lado nutricional, essa farinha de peixe era rica em proteínas e sais minerais, principalmente o cálcio, o que deveria suprir as necessidades deste nutrientes para essas tribos, já que não se encontram relatos de tribos que faziam uso do leite.

Os doentes eram eventuais. A robustez e resistência destes indivíduos pode ser observada na narração de STADEN (1974) em outro episódio. Ele diz que quando saíram à guerra, estavam a espreitar o inimigo que os avistou e tentou fugir. A resposta imediata foi a perseguição que durou, segundo Staden, pouco mais de quatro horas! Descontando o possível exagero na concepção temporal, normal a qualquer indivíduo que se presta a fazer uma atividade ingrata - Staden foi forçado a participar desta guerra - a força que estes índios deviam ter era fantástica.

CARDIM (1980) faz observações interessantes e mais detalhadas quanto aos tipos de peixes consumidos:

1. Peixes em geral:

- Peixe boi - segundo CARDIM (1980), sua carne era semelhante à do boi. Era consumido fresco ou salgado, ou ainda, "curava-se ao fumeiro como as de porco ou vacaf". Era um peixe gordo e "dava até toucinho". Da sua

\footnotetext{
f Os índios brasileiros não conheciam o gado vacum até a época do descobrimento. Parece não ter demorado a apreciação da carne desses animais pelos indígenas.
} 
gordura se fazia "manteiga" 8 ;

- Beijupirá, "de bom gosto e carnudo";

- Olho de boi, que segundo Cardim se pareciam com os atuns da Espanha. Também se tirava a gordura para fazer "manteiga";

- Camurupi ou pirapema, como é conhecido ainda hoje na região Norte. Descrito como agradável mas perigoso, uma vez que continham muitos espinhos na sua carne. Também se tirava a gordura para fazer "manteiga";

- Baleias e tubarões, de onde se retirava o óleo;

- Tartarugas, e seus ovos;

- Peixes voadores, que por vezes "voavam para dentro dos navios pelas escotilhas";

- Salmonetes e linguados, "não tão bons quanto os da Europa".

O autor faz menção, ainda, da existência de tainhas, garoupas, chicarros, pargos, sargos, gorazes, dourados, peixes agulha e pescadas, sendo que esta última era rara. Aponta, ainda, que o peixe na colônia era consumido no leite ou sobre outra carne, mas que na quaresma (por imposição dos costumes católicos) comiam os peixes sem azeite ou vinagre.

2. Outros alimentos de mar e rios: polvos, caranguejos, que por estarem presente em todo o litoral foram considerados alimento comum da terra, ostras, mexilhões, berbigões e lagostins; há uma menção ao fato de não eram tão grandes quanto as da Europa, talvez porque não houvesse lagostins e sim lagostas.

Os índios brasileiros não tinham costume de fazer grandes plantações, dada a sua natureza nômade, ao contrário, obtinham na natureza tudo o que fosse possível.

8. A manteiga por excelência é feita do leite, mas a denominação é dada pelo fato de essa gordura endurecer em temperatura ambiente, o que é próprio da gorduras saturadas. 
Das árvores frutíferas tinha-se o cajueiro e a jabuticabeira - comiam a fruta fresca e, também, a usavam para fazer vinho. Mangaba, macuoé, araçá, ombu, sapucaia, araticum, pequiá e pinhão também são citados (CARDIM 1980). A jaca, também, muito apreciada, era muito estranha aos olhos dos europeus (MESGRAVIS e PINSKY 2000). A Figura 36 é uma belíssima obra de Debret sobre as frutas do Brasil.

Figura 36 - "As frutas do Brasil".



Fonte: EFUSP 1998.

Dentre as frutas destacavam-se:

1. Caju - Consideravam-no fresco e digestivo, sendo usado no combate a febre. Dava, ainda, bom hálito a quem o consumisse pela manhã (numa época em que o banho fora recentemente aprendido, com os índios, ter um bom hálito deveria realmente ser algo impressionante). Mas o caju tinha, 
ainda, outra importante função: determinar o tempo. Os índios costumavam estabelecer suas idades pelas floradas do caju. Isso logo se tornaria muito útil aos europeus.

2. Naná (ou abacaxi). Era considerado o "rei das frutas" (MESGRAVIS e PINSKY 2000). O contraste marcante entre a aspereza da casca e seu interior perfumado e doce assombrava aos viajantes. Deste, também, se fazia vinho, muito apreciado, principalmente pelo seu gosto adocicado e delicioso perfume (CARDIM 1980), além da recuperação dos doentes.

3. Pacoba (ou, mais conhecida pelo nome africano, banana). A beleza de seus cachos encantava aos europeus. Era muito abundante em todas as parte e por isso mesmo considerado alimento comum (CARDIM 1980). Logo representou uma complementação na alimentação dos europeus aqui residentes, substituindo o uso da maçã, européia, sendo assada e usada para marmeladas, geléias ou seca ao sol. Foi considerada de grande ajuda na recuperação dos doentes. Uma bananeira, desenhada por Debret, pode ser vista na Figura 37.

4. Maracujá ou fruta da paixão (daí seu nome em inglês passion fruit) - Era muito apreciado por seu gosto azedo adocicado. Mas o aspecto que mais chama a atenção é que o padre Simão Vasconcelos fez um profundo estudo tentando argumentar que esta nova terra tinha todas as qualidades do paraíso. Ele acrescentou que a flor que os portugueses chamam de flor da paixão, tem em si alguns aspectos que representam a paixão de Cristo: coroa, coluna, açoites, chagas e cravos (MESGRAVIS e PINSKY 2000).

A Figura 37 mostra ilustrações de Debret sobre a flora brasileira. 
Figura 37 - Ilustrações da flora brasileira.

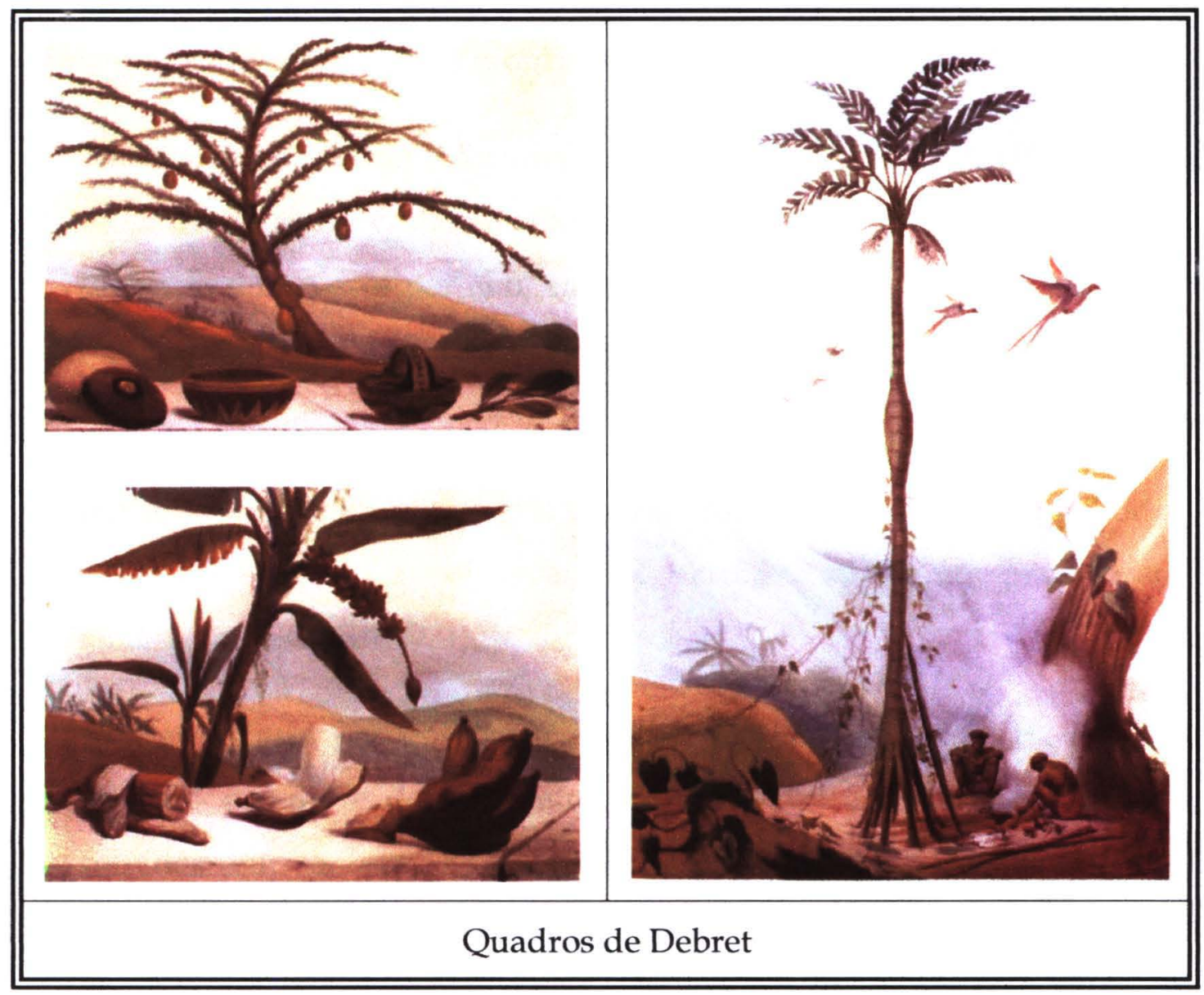

Fonte: EFUSP 1998

Nestas gravuras aparecem à esquerda a cabaceira e a bananeira, e à direita, o coqueiro "barrigudo". Os cocos não são nativos da América. Foram trazidos da Ásia bem no início da colonização, mas se adaptaram tão bem que sua presença já enfeitava muitas cenas da colônia, imortalizadas por gravuras como esta.

\subsection{2 - A lavoura indígena: presentes da natureza}

Apesar de não serem conhecidos como agricultores, muitas tribos mantinham pequenas lavouras, que tinham quatro características principais: 
eram de fácil plantio, tinham boa resistência, capacidade de se desenvolver sem muitos cuidados, e que produzisse frutos rapidamente. Dentre esses alimentos são descritos pelos cronistas:

1. Jerimus (ou abóbora) - Segundo a observação de SOUSA (1971), havia cerca de 10 a 12 castas de abóbora, cada uma com uma feição. Eram plantada duas vezes por ano, em terra úmida e solta. Quando brotavam espalhavam-se pelo chão e davam em boa quantidade.

2. Amendoim - Os amendoins eram enterrados há um palmo de distância um do outro. Eram plantado em fevereiro e já em maio eram colhidos. Cada pé, segundo a observação do cronista, dava um prato destes amendoins (SOUSA 1971).

3. Batatas - uma vez que eram plantadas não precisavam de nenhum cuidado e sempre davam frutos. Se plantadas em Abril, podiam ser colhidas em Agosto. Caso houvesse batatas ainda pequenas, estas permaneciam na terra até ficarem maiores. SOUSA (1971) não diz que eram os índios que as plantavam, mas que era usada por eles. Talvez os portugueses já tivessem aprendido a lidar com esta raiz. CARDIM (1980) cita as batatas, sem contudo discriminá-las. Menciona que eram usadas para fazer pão. Por outro lado, pela imprecisão das informações, pode tratar-se da batata doce.

4. Carás e inhames - Eram cultivados do mesmo modo que as batatas, tendo o mesmo tempo para crescimento. Eram comidos cozidos ou assados. Sua ilustração está na Figura 38.

5. Mangarás e taiobas - À semelhança das batatas e carás, esta era uma raiz praticamente com as mesmas características. Entretanto, suas folhas também eram comestíveis. SOUSA (1971) as compara ao espinafre, com folhas maiores, como mostra a Figura 38. 
6. Mandioca - LÉRY (1980) descreve: “...o mais admirável, porém, nessas raízes, é o modo de se reproduzirem no Brasil. O caule é mole e frágil como o do cânhamo e basta quebrar e enterrar um pedaço dele para que, sem maiores cuidados três meses depois estejam formadas sob a terra as grossa raízes..." (p. 126), como mostra a Figura 38.

Figura 38 - Elementos da flora brasileira: favas para colares, urucum para tatuagens, taioba, cará e mandioca.

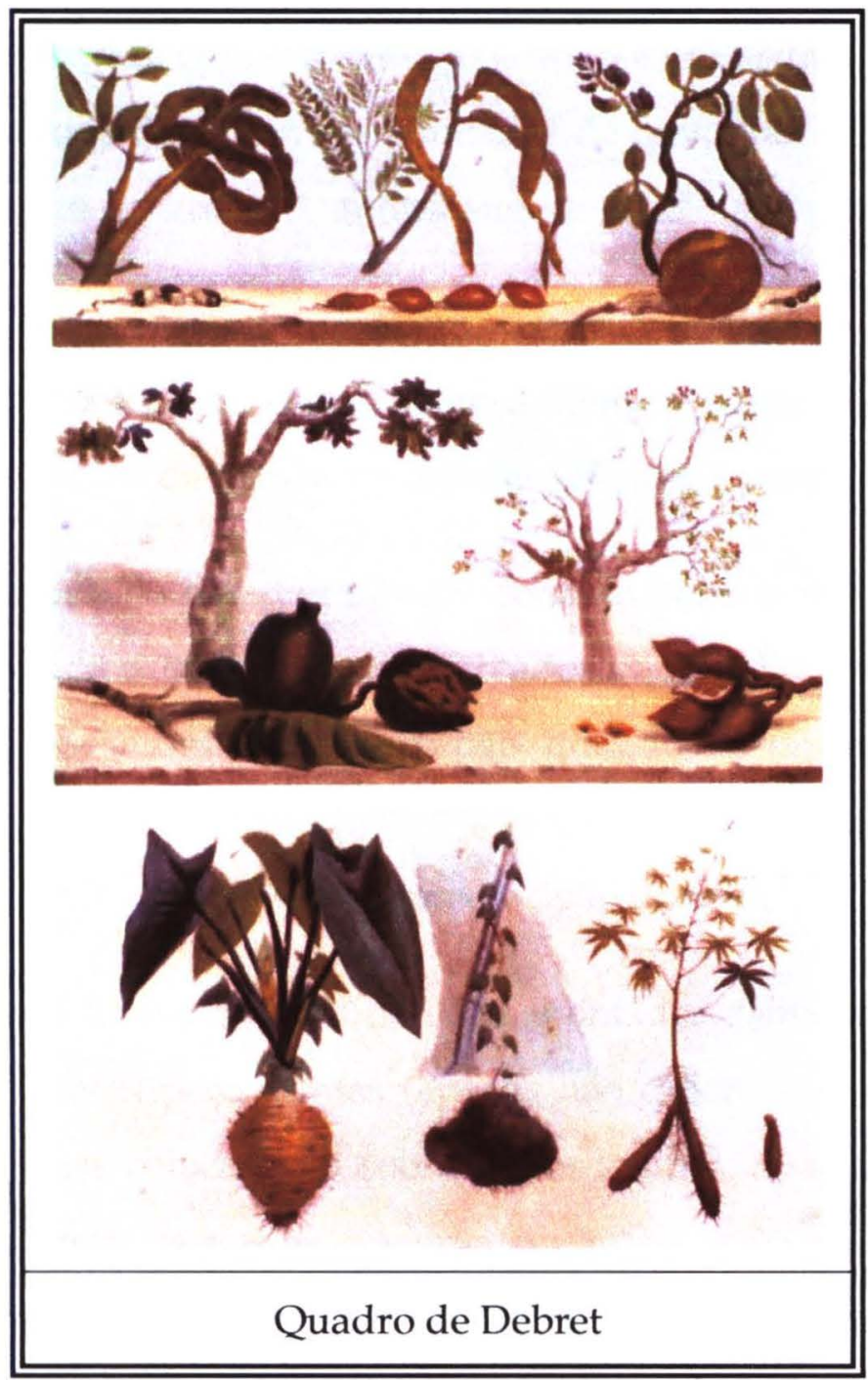

Fonte: EFUSP 1998. 
7. Milho - "...as mulheres também plantam duas espécies de milho, branco e vermelho, fincando no chão um bastão pontudo e enterrando o grão no buraco..." (LÉRY 1980, p. 126). "Este milho se planta por entre a mandioca [...] e colhe-se a novidade aos três meses..." (SOUSA 1971, p. 182).

ORNELLAS (1978) descreve uma lenda que explica o cultivo desses alimentos: Sinaá, o pajé grande, que existia antes do conhecimento de todas as coisas, juntamente com outros indivíduos puseram fogo numa sucuri que ficara brava. "De suas cinzas nasceram: mandioca, batata, cará, milho, abóbora, pimenta, mamão e banana" (p.187). Como eles não sabiam o que fazer com essas plantas, apareceu um passarinho e os ensinou que poderiam ser comidas mas que deveriam ser plantadas de novo todo fim das chuvas, para que voltassem a nascer. A autora sugere se não seria esse o início da coivara.

Desses alimentos que compunham a lavoura indígena, dois ganham destaque nas narrações de vários cronistas e viajantes, a mandioca e o milho.

A importância da mandioca é representada por sua versatilidade bem explorada pelos índios. Mais tarde os derivados da mandioca resultavam em bolos, mingaus, queijadinhas e até em pão, quando misturado com farinha de milho ou de arroz e fermento (levedo). Era considerada como o alimento comum da terra, mais tarde descrito como o "pão da terra".

Outros usos da mandioca ainda são apontados: fabricação de vinho e remédio contra cobras peçonhentas (apenas não descreve se é bebendo ou comendo, ou apenas colocando-a sobre a mordedura). Suas folhas também são comestiveis; para os índios era uma opção de alimento em época de necessidade.

A origem de seu uso é desconhecida, mas os índios usavam lendas para ilustrar o início de sua existência. Uma delas diz que nasceu entre os 
índios uma criança loura, de nome Mandi, o que era inaceitável (provavelmente um albino), e que esta fora enterrada na oca (os índios tinham o costume de enterrar ainda vivas as crianças que nasciam com deformidades). Daí teria surgido a Mandi-oca (ORNELLAS 1978).

O que chama a atenção de CARDIM (1980) é, segundo ele, o fato de não ser necessário celeiro para guardá-la porque se não forem colhidas, permanecem até oito anos embaixo da terra. Quanto mais tempo ficam, maiores e mais grossas se tornam.

É muito venenosa se consumida crua, tanto para homens quanto animais. Hoje se sabe que ela contém ácido cianídrico (HCN), altamente tóxico, mas volátil e, por isso, eliminado com a presença de calor ou de ar. Infelizmente não existem dados que esclareçam mais dúvidas sobre seu grande uso pelos indígenas, mas o que se pode concluir é que este conhecimento, obtido pelos seus ancestrais, perdurou durante muito tempo, até a chegada do homem branco, que daquele momento passa a narrar sua história.

CARDIM (1980) faz uma descrição detalhada, e talvez a melhor de todos os cronistas, quanto ao processo todo: A raiz era ralada e misturada com água para ser lavada. Essa mistura de raiz com água era peneirada e seca. Tinha-se, então, a farinha de mandioca. Esta água que escorria era branca e rica em amido; quando colocada em uma vasilha e posta para descansar, o sedimento ia para o fundo e a parte superior da água ficava transparente. A partir deste momento tinha-se duas opções, escorrê-la e secála (para a obtenção do que chamamos hoje de polvilho doce), ou esperar mais dois ou três dias, até "coalhar" (como diz o cronista), para, então, escorrer (e obter o polvilho azedo). Deste último os índios confeccionavam os beijus polvilho com água assado - e os biscoitos - polvilho escaldado com água fervente. Estes últimos eram muito apreciados e logo surgiram como 
sucedâneos dos famosos biscoitos usados nas viagens marítimas, quando os portugueses iam daqui para lá.

Algo interessante é o hábito de comerem a farinha de mandioca com um "arremesso", o que era comum em várias regiões (se ainda não o é), como descrito para algumas regiões de Minas, por FRIEIRO (1982).

O milho, para Peckolt, citado por FREYRE (1963), parece ter sido o único cereal encontrado no Brasil. LERY (1980) lembra, ainda, que este milho seria o que a narração do historiador das Índias chama de maïs e que serve de trigo para os índios do Peru. $\mathrm{O}$ historiador citado descreve o maïs: "...cresce à altura de um homem e mais; é bastante grosso e lança folhas como as da cana das lagoas; a espiga é como uma glande de pinho silvestre [...] amadurece em três ou quatro meses e nas terras bem banhadas em mês e meio..."(p. 128).

O milho não recebeu tanto destaque por CARDIM (1980), mas é descrito como próprio para confecção de pães e vinho, para comer a espiga assada e engordar cavalos, porcos e galinhas. SOUSA (1971) também observa isso.

É uma planta, que como a mandioca, não necessita grandes cuidados para seu plantio e quanto a sua origem, também está associada ao crescimento da planta sobre a sepultura de um chefe da tribo Pareci (ORNELLAS 1978).

Infelizmente LÉRY (1980) se perde na discussão de que esta nova terra poderia produzir trigo (como já o estava sendo em São Vicente), e não retoma a questão do milho. Por outro lado ele dá indícios de que o milho era consumido da mesma forma que a mandioca, em mingaus, como farinha, etc. 
Segundo a descrição de antigos moradores ${ }^{\mathrm{h}}$, criados em fazendas no interior de São Paulo e Minas Gerais, o processo de obtenção da farinha de milho consiste em deixar o milho secar ainda no pé. Este era, então, debulhado e colocado no monjolo, equipamento movido a boi ou a moinho de água, para ser amassado. $\mathrm{O}$ milho amassado era peneirado; a parte grossa (farelo) era desprezada. A parte fina era colocada num cocho e misturada com água, permanecendo, assim, por uns oito dias - a água era trocada uma ou duas vezes durante este período. Após isso o milho era bem lavado e posto para escorrer dentro do balaio. Voltava, então, para o monjolo e era amassado. Por estar o grão hidratado obtinha-se uma pasta dura e grumosa; passava-se de novo peia peneira: a parte grossa voltava para o monjolo e a parte fina era colocada em uma espécie de frigideira bem grande (cerca de 1 $m$ de diâmetro) que era montada em cima de um tipo de forno: montava-se os tijolos ou pedras de forma circular, colocava-se a brasa dentro e a frigideira por cima. A massa de milho começava a secar e torrar. Era, então, passada uma pá pelo fundo de onde se desgrudavam os torrões da farinha de milho e estava pronta para ensacar. A diferença básica entre a farinha de milho e o fubá é que este último não passa por nenhum processo de cocção, sendo apenas o milho seco finamente moído e peneirado.

Das preparações com milho herdadas dos índios tem-se a farinha de milho, a canjica (acanijic), a pamonha (pamuna) e a pipoca, que para Teodoro Sampaio quer dizer "epiderme estalada" (FREYRE 1963)

\subsection{3 - Costumes alimentares, culinária e utensílios}

Os índios também condimentavam a sua comida. A pimenta, segundo Sigaud, citado por FREYRE (1963), tinha amplo uso entre os indígenas, e até demasiado. Era apontada por ele como a causa de muitas disenterias,

h Dados obtidos em entrevistas. 
principalmente quando associadas ao gengibre e limão. De modo geral, entretanto, deveria ser muito apreciada: “...quando os índios cozinham peixe ou carne, põem dentro habitualmente pimenta verde. Logo que está um tanto cozida, retiram-na do caldo e fazem dela uma papa fina que chama mingau. Bebem-no em cabaças ..." (STADEN 1974, p. 164). Esse "mingau" pode ser o precursor do atual pirão, que é preparado do mesmo jeito: dissolve-se a farinha de mandioca em um caldo temperado de peixe que ferve, até que a farinha esteja cozida.

SOUSA (1971) descreve seis tipos diferentes de pimentas que eram usadas pelos índios. Acrescenta, ainda, que todas dão frutos durante muito tempo, sendo fácil encontrá-las. Não é mencionada nos itens da lavoura, talvez, porque eram disseminadas nas fezes dos índios, já que suas sementes não são digeridas pelo organismo. Ele menciona, ainda, que quando não tinham nada para comer com a farinha de mandioca, acrescentavam pimenta seca moída para dar mais gosto à "refeição". Os portugueses rapidamente aprenderam a apreciar e usar essas pimentas. Costumavam secá-las e moêlas, a exemplo dos índios, mas misturavam-nas ao sal, que acrescentavam às carnes e peixes para condimentá-los: "...na qual molham o peixe e a carne, e entre os brancos se traz no saleiro, e não descontenta a ninguém..." (p. 185).

Na obtenção de melhores sabores os índios, também, adicionavam cinzas às preparações; estas faziam as vezes do sal. STADEN (1974) descreve o processo de obtenção desta cinza: "...abatem uma palmeira grossa e a picam em pequenas lascas. Fazem depois uma caieira com lenha seca, colocam em cima estas lascas, queimando-as e reduzindo-as à cinzas. Desta fazem uma barrela, que cozem. Separa-se então uma coisa, que tem aparência de sal. Pensei que fosse salitre e provei-o no fogo. Não era porém. Tinha gosto de sal e era de cor cinzenta." E acrescenta: "...mas a maioria das tribus não usa sal..." (p.163). 
Sabe-se hoje que a cinza (de materiais orgânicos, como madeira, etc.), resultado da combustão dos elementos, é composta basicamente de sais minerais, uma vez que os outros componentes se perdem. Daí o seu uso pelos indígenas.

Outros hábitos observados tem relação com os modos (ou a ausência deles, na opinião de alguns cronistas e viajantes): Não lavavam as mãos e nem davam graças, e após comerem limpavam as mão nos cabelos, no corpo ou nas árvores. Não tinham toalhas, mesas, mas comiam sentados, deitados em redes ou de cócoras no chão. Enquanto comiam não bebiam. Após a refeição é que bebiam água ou vinho, feito de muitas frutas. Bebiam tanto que até caiam.

LÉRY comenta: "Cumpre notar que embora não observem horas de jantar, merendar ou cear, como o fazemos, nem trepidam em comer à meianoite ou ao meio-dia, só o fazem quando têm fome..." (p.131).

Os índios não faziam uso do sal para a conservação dos seus alimentos, como já mencionado. Por outro lado desenvolveram uma técnica para desidratar muitos alimentos e conservá-los por muitos meses chegando alguns alimentos até um ano. Era o processo de "moquear", o mesmo usado na obtenção da farinha de peixe, anteriormente citada.

LÉRY (1980) dá uma descrição da aparência que tinha o boucan, ou o que poderia ser modernamente chamado de "equipamento de moquear" (que vem de moknen ou moquém, que significa "assar sobre a brasa"): "os americanos enterram profundamente no chão quatro forquilhas de pau enquadradas à distância de três pés e à altura de dois pés e meio; sobre elas assentam varas com uma polegada ou dois dedos de distância uma da outra, formando uma grelha de madeira a que chamam boucan. Têm-nos todos em suas casa e nele colocam a carne cortada em pedaços acendendo um fogo lento por baixo, com lenha seca que não faça muita fumaça, voltando a carne 
e revirando de quarto em quarto de hora até que esteja bem amassada. Como não salgam suas viandas para guardá-las, como nós fazemos, esse é o único meio de conservá-las"(p. 136).

SOUSA (1971) menciona outros alimentos que também passavam por esse processo:

- Abóbora: "...costuma o gentio cozer e assar estas abóboras inteiras por the não entrar água dentro, e depois de cozidas as cortam como melões, e lhes deitam as pevides fora, e são assim mais saborosas que cozidas talhadas, e curam-se no fumo para durarem todo o ano...". (p. 184).

- Amendoins: "...e para durarem o ano todo curam-nos [os amendoins] no fumo, onde os têm até vir outra novidade..." (p. 185). Daí, talvez, o uso do amendoim torrado como aperitivo, já que podiam comê-lo durante todo o tempo.

- Milho: “...e de outra [casta de milho] se curam ao fumo, onde se conserva para se não danar; e dura de um ano para o outro..."(p. 182). Esse processo de assar o milho sobre o fogo aparece nesta gravura de Debret como uma prática desempenhada por escravas negras, que os vendia na rua, como mostra a Figura 39, ainda na segunda metade do século XIX. Até hoje é possível encontrar vendedores ambulantes de milho assado em muitas cidades do Brasil.

Não é difícil concluir que comiam todas as partes de um animal, já que em algumas gravuras vê-se que comiam todas as partes dos homens mortos nas cerimônias. Há até um episódio quando os tubinambás matam um índio carijó que estava doente, e STADEN os adverte para que não o comam por causa da sua condição. Porque tinha má aparência tiveram nojo de comer a cabeça e os intestinos. Mas as demais partes comeram todas. 
Figura 39 - Escrava negra vendendo milho assado na rua.

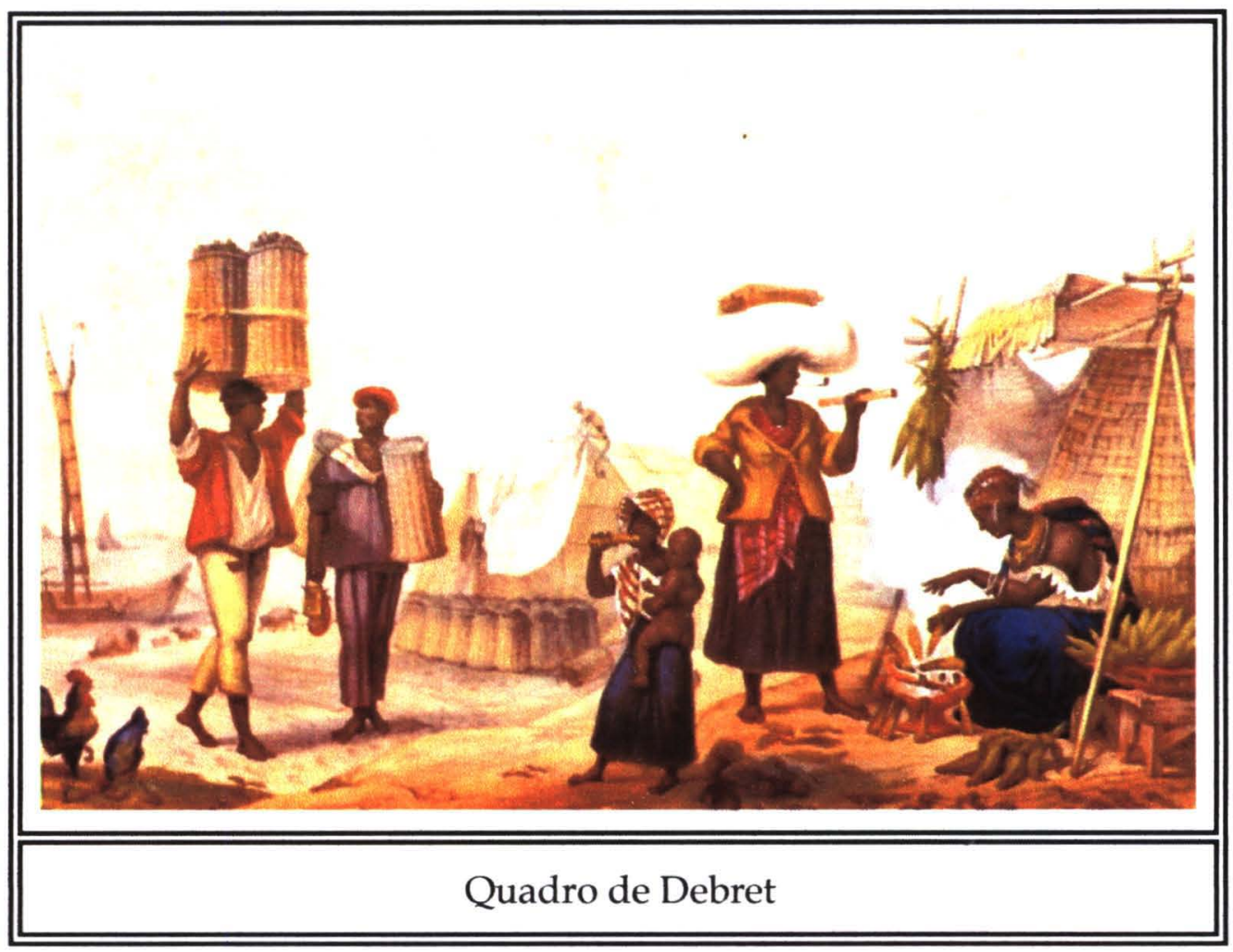

Fonte: EFUSP 1998

Muitas foram as contribuições dos índios ao processo de permitir a permanência dos homem branco à nova terra, mas, quanto à alimentação, talvez, a contribuição mais importante diz respeito ao processo, hoje chamado, culinário. Os utensílios e o modo como os alimentos eram conservados e preparados têm grande significado, pois, muitos deles, depois de "abrasileirados", permanecem até hoje em muitas regiões do Brasil.

Os utensílios eram feitos com as próprias mãos. STADEN (1974) descreve o seu processo de fabricação: “...tomam barro, assam-no e fazem estão as vasilhas que querem ter. Depois as deixam secar durante algum tempo. Sabem também pintá-las com gosto. Quando querem queimar as vasilhas, debruçam-nas sobre pedras, põem aí bastante cortiça seca, que 
ateiam. Assim se queimam as vasilhas, de modo que incandescem como ferro em brasa" (p.165). LÉRY (1980) durante suas descrições menciona diversos tamanhos destes potes, que serviam a vários fins. Isso parece bastante apropriado pois, quando se quebravam, faziam mais. A Figura 40 mostra índias tupinambás usando seus potes de barro.

Figura 40 - Índias tupinambás usando seus potes de barro.



Fonte: STADEN 1974, p. 166

Sobre um outro tipo de abóbora, conhecida em Portugal pelo nome de cabaços SOUSA (1971) acrescenta: “...Essas abóboras ou cabaços semeia o gentio para fazer delas vasilhas para seu uso, as quais não costuma comer, mas deixam-nas estar nas aboboreiras até se fazerem duras, e como estão de vez, curam-nas no fumo, de que fazem depois vasilhas para acarretarem água, por outras pequenas bebem, outras meias levam às costas cheias de água quando caminham; e há alguns destes cabaços tamanhos que levam 
dois almudes e mais, nos quais guardam as sementes que há de plantar; e costumam também cortar esses cabaços em verdes, como estão duros, pelo meio, e depois de curadas essas metades servem-lhes de gamelas, e outros despejos, e as metades dos pequenos servem-lhes de escudelas, e dão lhes por dentro uma tinta preta, por fora outra amarela, que se não tira nunca; e estas são suas porcelanas." (SOUSA 1971, p. 184).

FREYRE (1963) cita outros utensílios: os alguidares (potes de água feitos de argila), urupemas (pilão para socar), cuias, cabaças e balaios. Mesmo nas cidades grandes há um grande número de residências que ainda mantêm esses tipos de utensílios. São feitos basicamente de madeiras, argila, cascas de ostras e pedras. A Figura 41 mostra alguns utensílios feitos de madeira usados na colônia do século XIX.

Outros processos culinários que chamam a atenção são a moqueca e o mixirir. A palavra moqueca vem de pokeka e significa "embrulho". O peixe era embrulhado em folhas de bananeira e assado no rescaldo. Esta preparação modificou-se um pouco pelo toque da negra que passou também a trabalhar na cozinha. $O$ prato que se conhece hoje é o resultado desta mistura cultural. Mixirir é conservar a carne, cozida em fogo brando, na sua própria gordura e guardá-la em potes apropriados, geralmente de barro; é usado peixes de grande uso, como o tucunaré e o tambaqui, ou em carnes; tartarugas e antas também eram conservados assim (FREYRE 1963).

Salgar e secar ao sol aparece em algumas narrações. Este processo era usado com muitos peixes: o pirarucu, que substituía o bacalhau ou o charque: "é aproveitado em conserva, salgado apenas (salmoura) para o consumo de dias mais próximos, ou salgado e dessecado ao sol (seco), em mantas, para resistir muito mais tempo". Este processo parece ter sido incorporado pelos índios um pouco depois da chegada dos europeus. 
Figura 41 - Utensílios de madeira e barro.

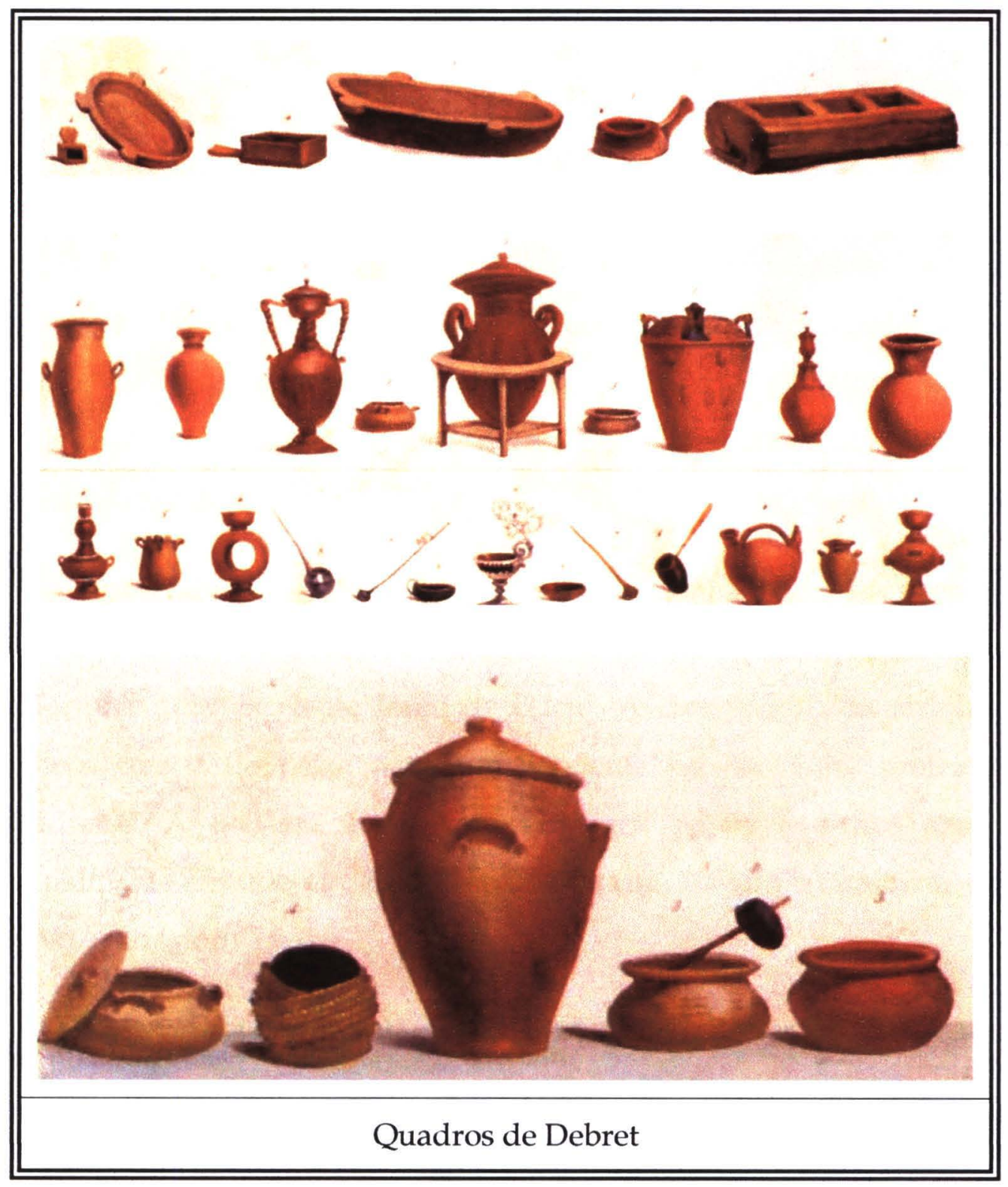

Fonte: EFUSP 1998.

É necessário recordar que os primeiros contatos do homem branco com os índios se deu de modo "informal", por assim dizer, já que o processo de ocupação e colonização do Brasil demorou pelo menos 30 anos, nos quais algumas nações como França e Holanda, já mantinham contato com os índios, trocando, principalmente, o pau-brasil por outras mercadorias. Além 
disso, STADEN (1974) menciona que os índios brasileiros não usavam o sal e sim as cinzas para temperar, como já mencionado.

\subsection{4 - A alimentação}

Pode-se notar, pelas narrações, que a alimentação indígena apresentava um equilíbrio quanto aos tipos de alimentos consumidos e, portanto, de seus nutrientes. Todos os grupos de alimentos estariam supridos, a não ser grupo do leite e derivados, o que poderia ocasionar uma deficiência de cálcio.

Entretanto, o cálcio estaria suprindo pela farinha de peixe: as espinhas eram moqueadas juntamente com a carne e algumas vísceras, o que tornava essa farinha uma excelente fonte de cálcio. A combinação da farinha de mandioca com a de peixe dava um excelente balanço entre proteínas e carboidratos. A gordura certamente viria em peixes e outros animais, principalmente em suas vísceras como fígado, rim, cérebro e intestinos, ricos, também, em fósforo e ferro.

É possível concluir, portanto, que a dieta indígena era equilibrada e as refeições, apesar de irregulares, supriam de maneira satisfatória as necessidades alimentares. Outro fato que corrobora com essa conclusão são as descrições dos cronistas e viajantes que, raras vezes, mencionam doenças entre os índios, inclusive os desenhando e descrevendo como muito belos e fortes em sua estrutura física. NÓBREGA (1988) chega dizer que nunca tinha ouvido dizer que algum tivesse morrido de febre, apenas de velhice. 


\section{4 - O MUNDO COLONIAL: BASES PARA A FORMAÇÃO DA BRASILIDADE ALIMENTAR}

Hábito alimentar pode ser definido como o "costume de uma comunidade que reflete a forma com que sua cultura traça a norma de conduta dos indivíduos da sociedade em relação ao alimento, do que resulta ter o grupo um padrão dietético comum" (LOWNBERG et al. 1970, p. 97). Ou ainda como "as predileções alimentares constituídas através dos séculos e que passaram a fazer parte da cultura de um povo" (PHILIPPI 1992, p. 2).

Em outras palavras, poder-se-ia dizer que hábito alimentar é o que um indivíduo, ou uma coletividade, prefere ou gosta de comer: alimentos específicos, preparações, tipos de condimentos, técnicas de preparo, etc. Esse conjunto de elementos, entretanto, tem uma razão para ter sido assim definido. A inclusão ou exclusão desses elementos são o resultado de fatores externos à própria alimentação.

May, citado por LOWENBERG et al. (1970), afirma que os fatores que regem a dieta do homem podem ser assim classificados: primeiramente o homem come o que pode encontrar ao seu redor e, quando pode escolher, escolhe o que seus antepassados comeram antes dele.

Como mostra a Figura 42, o hábito alimentar pode passar basicamente por 5 fases:

1 - Sobrevivência: seria a etapa mais elementar nesta representação, uma vez que sugere não haver a possibilidade de escolha por parte do indivíduo. A vida estaria ameaçada pela não utilização dos recursos disponíveis. É o que se pode notar, por exemplo, nos relatos das viagens. Os marujos acabavam 
comendo o que estava disponível, até mesmo os ratos que infestavam os navios da época.

Figura 42 - As etapas da necessidade alimentar.

\begin{tabular}{|c|c|c|c|c|}
\hline$\Rightarrow$ & $\Rightarrow$ & $\Rightarrow$ & \multicolumn{2}{|c|}{$\Rightarrow$ direção normal } \\
\hline $\begin{array}{c}1^{\circ} \\
\text { sobrevivência }\end{array}$ & $\begin{array}{c}2^{\circ} \\
\text { segurança }\end{array}$ & $\begin{array}{c}3^{\circ} \\
\text { associação a } \\
\text { grupos }\end{array}$ & $\begin{array}{c}4^{\circ} \\
\text { estima ou } \\
\text { posição }\end{array}$ & $\begin{array}{c}5^{\circ} \\
\text { auto } \\
\text { realização }\end{array}$ \\
\hline $\begin{array}{l}\text { necessidade } \\
\text { fisiológica }\end{array}$ & $\begin{array}{l}\text { necessidade } \\
\text { fisiológica e } \\
\text { social }\end{array}$ & $\begin{array}{c}\text { necessidade } \\
\text { social }\end{array}$ & $\begin{array}{c}\text { necessidade } \\
\text { social }\end{array}$ & $\begin{array}{c}\text { necessidade } \\
\text { social }\end{array}$ \\
\hline direçã & desastrosa & ↔ & $\hookleftarrow$ & 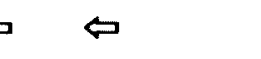 \\
\hline
\end{tabular}

Fonte: LOWENBERG et al. 1970.

2 - Segurança: indicaria um nível onde há uma pequena possibilidade de escolha, sendo esta, porém, intimamente ligada às lembranças de bons momentos, como infância ou, como exemplificado por Moore, citado por LOWENBERG et al. (1970), quando soldados, no campo de batalha, feridos e infelizes, atribuíam ao leite a expressão de bem-estar e comodidade que gozavam em suas casas.

3 - Associação a grupos (ou como classificam KRAUSE e MAHAN (1991) "preceitos morais, religiosos ou os ligados a crenças"): optar por alimentos que classificariam ou identificariam os indivíduos como parte de uma determinado grupo caracterizaria este nível. Um bom exemplo seriam as obrigações alimentares que certas religiões impõem aos seus seguidores. 
4 - Estima ou posição: abrangeria os indivíduos que podem ceder aos apelos de uma campanha publicitária, por exemplo. É neste ponto que se encontram a maioria das pessoas que aderem a produtos dietéticos, ou se obrigam a comer algo que consideram importante para sua saúde. Por exemplo, SIMOPOULOS (1989) menciona que "a crença de que certos alimentos conferiam superior destreza para o atleta que os consumia datam, pelo menos, de 450 a.C. A história conta que alguns atletas consumiam enormes quantidades de carne; Milo, de Croton (uma cidade famosa por seus atletas), foi reputado como tendo comido $9 \mathrm{~kg}$ de carne, $9 \mathrm{~kg}$ de pão, e 8,5 litros de vinho em um dia; ele foi o mais famoso de todos os lutadores gregos" (p. 924). Ou ainda FRIEIRO (1982) que diz ser bem incomum a ingestão de carne de carneiro, em Minas Gerais dos séculos XVII e XVIII, por ser este animal associado à imagem de Cristo, o "cordeiro de Deus".

5 - Auto realização: neste ponto o indivíduo já está tão seguro, e tem a sua disposição o que quiser, que se aventura a criar suas próprias receitas. Ou ainda, por seu próprio contentamento, arrisca-se a experimentar alimentos exóticos. Towsend (1928), citado por LOWENBERG et al. (1970), diz: “O cosmopolita culto não hesita em provar alimentos estranhos. Não é assim com o selvagem, a criança e o ignorante. Nestas três categorias abundam os prejuízos em matéria de alimentação, muitas vezes curiosos e irracionais" (p. 118).

KRAUSE e MAHAN (1991) citam, ainda, que a questão cultural, também, está intimamente ligada ao que cada indivíduo se torna. Os primeiros passos na vida em direção às práticas que se tornarão rotina começam no cenário familiar. $\mathrm{O}$ hábito de comer alguns alimentos, bem como o modo como são preparados, provavelmente acompanharão cada indivíduo durante toda a sua vida. 
Há, porém, algumas considerações. O hábito alimentar de um indivíduo, ou mesmo de uma família, não é imutável. A convivência com indivíduos de outras procedências, mais cedo ou mais tarde, contribuirá, mesmo que em menor grau, para a mudança do hábito alimentar.

QUERINO (1988) descrevendo uma de suas viagens, por exemplo, diz: "passeando um dia pelas ruas de Belgrado (capital do novo reino ServoCroata-Sloveno) percebi na frente de uma modestíssima bodega uma mesa onde se achavam um samovar e um kanta; o samovar é o utensílio de cobre que serve para fazer chá; o kanta é um vaso cravado de cobre no qual se fabrica e vende a boza, que é uma bebida de farinha de milho fermentada. Ora, o samovar e o chá exprimem um costume russo, enquanto que a boza é de origem turca. Nesse país eslavo, que por tanto tempo esteve sob o domínio dos turcos, as influências da Rússia e da Turquia estão flagrantemente figuradas pela justaposição inesperada do samovar e do kanta (p. 134)

Quanto às questões sociais, pode haver uma mudança, principalmente, se um alimento está associado à imagem de um extrato social superior. Sobre a Idade Média RIERA-MELIS (1998) cita que "nas camadas sociais mais baixas, predominam os alimentos de origem vegetal em detrimento da carne [...] Cada classe social atribui [aos alimentos] valores diferentes e os combina à sua maneira, para constituir seu próprio sistema alimentar. Assim, a mesa torna-se um forte elemento de identidade coletiva" (p.394). E ainda: "No imaginário coletivo da época [séculos XII e XIII], a alimentação abundante e sobretudo a quantidade de carne continuam sendo símbolo do poder, de fonte de energia física, de potência sexual e representam uma das principais manifestações da alegria de viver e da felicidade" (p. 397). 
Outros fatores relacionados, como mudanças forçadas, também interferem: as guerras e catástrofes naturais, por destruírem os alimentos, desde as possibilidades de plantio até às perdas de estoques; perda do poder aquisitivo dos indivíduos ou até de uma nação, por limitar, em muitas esferas, a aquisição e disponibilização dos alimentos e, ainda, a troca de ambientes sociais, como mudanças para outras regiões ou países, o que pode definitivamente impedir a aquisição de certos alimentos; por último, o confinamento carcerário, que por sua característica institucional, é rígido e, muitas vezes, imutável.

É de se supor que se uma população fica dependente definitivamente de uma dada circunstância, seja ela de qualquer natureza, as primeiras gerações resistirão às mudanças, mas com o passar dos tempos as próximas gerações poderão incorporar esses novos hábitos como próprios seus, muitas vezes por falta de opção.

Pode-se concluir, também, que o hábito alimentar em si não mude, mas, devido às pressões externas, seja mesclado ou adaptado aos alimentos disponíveis, de modo a atender a necessidade gerada pela força do hábito.

Com relação à colônia na América as primeiras experiências neste sentido seriam sentidas já durante a viagem, quando houve falta de alimentos.

Na narração de Gaspar Correia, em Maio de 1510, ele diz: "em toda 'armada avia grão padecimento de fome, que era tanta que comião os ratos que podião tomar, com que sempre andavão à caça...; porque o peixe do rio não mordia ao anzolo, e algum que matavão se dava por amor de Deos aos mais doentes, que erão muytos em toda armada" (MENEZES 1987, p. 68).

Os marujos, e eventualmente os passageiros destas expedições, estavam constantemente expostos a novos alimentos, exatamente pela 
precariedade do abastecimento. Relatos sobre a viagem de Vasco da Gama comprovam isso, pois, as tentativas de negociar suprimentos nem sempre eram bem sucedidas.

Este fato fica muito claro nas palavras de Estevão da Gama, primo de Vasco da Gama, que narra o encontro dele com seu primo, o qual tinha em sua tripulação grande número de doentes, por conta de sua segunda viagem às Índias. Neste momento, Vasco da Gama estava atracado em uma parte da costa africana. Estevão diz: "vierão ter à nossa náo alguns homens negros... traziam a vender-nos peixe cru, e cozido, e pepinos, e... huma espície de figos compridos, e grandes como pepinos pequenos, que he hum dos fructos mais saborosos que pode haver no mundo, e dos quaes ainda que se coma hum cesto cheo, não fazem mal algum nem empachão o estomago" (MENEZES 1987, p. 48 e 49$)$.

Este trecho mostra claramente a capacidade que estes homens tinham de experimentar e gostar de alimentos aos quais não estavam acostumados, sendo o sabor fosse familiar (como no caso de comparar aos figos a fruta consumida), ou não.

No caso do Brasil, a mistura do hábito alimentar indígena, português e negro, somados a outros fatores de maior grandeza - como a questão da política mercantilista e de subsistência, que acabavam determinando a disponibilidade e a possibilidade de aquisição de gêneros, entre outros acabou por caracterizar seu sistema alimentar.

$\mathrm{Na}$ leitura das primeiras descrições dos cronistas da época, como CARDIM (1980) e SALVADOR (1982), observa-se uma descrição rica, naturalmente cheia de esplendor e variedade quanto aos seus componentes alimentares, facilmente verificável pela beleza e saúde dos índios. O capítulo anterior, que descreve o modo de vida indígena, bem como a qualidade de sua alimentação, baseada em carnes e frutas, dá detalhes destas descricões. 
Este esplendor encantou e deslumbrou os olhos dos recém chegados de além mar, como pode ser verificado na primeira carta de Pero Vaz de Caminha enviada a Portugal (NPILL 2001).

A observação, entretanto, de outras narrações de épocas subseqüentes levam a fazer algumas considerações importantes: as cenas presenciadas pelos padres representariam apenas pequena parcela da vida cotidiana da colônia, momentos de festa ou de recepção aos viajantes (FREYRE 1963). Deste modo, é possível inferir que a realidade do dia a dia colonial era dura e marcada pelo desequilíbrio alimentar. $O$ modo de vida indígena, basicamente nômade, já não era apropriado para alimentar um número crescente de indivíduos, como ocorria na colônia. A paisagem da costa começou, pouco a pouco, a mudar e, portanto, também, o habitat de muitos animais para caça. A vegetação nativa passou a dar lugar para espécies estrangeiras como a cana de açúcar. Começavam na colônia os mesmos problemas da Europa.

Durante os séculos XVI e XVII a Europa apresentou sérios problemas relacionados ao abastecimento de sua população, como apontado anteriormente. MOUSNIER (1957), por exemplo, expõe que as populações européias se apresentavam predominantemente agrícolas, e mesmo assim havia um quadro de fome endêmica. Os esforços para enfrentar essa condição foram se voltando para aumentar o plantio de cereais ao invés de criar animais. Tais medidas são compreensíveis quando se lembra de Fernand Braudel, citado por FLANDRIN (1998): “...um hectare destinado ao cultivo de trigo resultava, nas condições técnicas da época, em cinco quintais de trigo, que forneciam 1,5 milhão de calorias; a mesma área, usada como pastagem, produzia, quando muito, 1,5 quintal de carne de boi que não fornecia mais de 340 mil calorias". Segundo ele "para manter o crescimento demográfico, era preciso substituir parte das pastagens por campos de cereais e diminuir sensivelmente a carne na dieta popular, aumentando o 
consumo de pão" (p. 534). O rendimento calórico dos cereais é bem superior ac da criação de animais, para um mesmo espaço físico.

As técnicas de cultivo, entretanto, não atendiam a um aumento da produção, de modo que o crescimento vegetativo, observado nas épocas de fartura, era compensado com as altas taxas de mortalidade dos longos períodos de fome: o número médio de habitantes de uma região variava muito pouco ao longo do tempo. MOUSNIER (1957) registra o ciclo destas épocas: "...no primeiro ano a mortalidade cresce pouco, pois, para subsistir, o camponês vende sua vaca, o artífice as suas ferramentas e os que possuem reservas consomem-nas ou vendem-nas..." (p. 162). Mas se o problema persistia aí sim, vinham a fome, as enfermidades e as epidemias.

Se as condições eram precárias na Europa, que dirá exportar produtos de subsistência para a colônia. Estes eram escassos, tornavam-se caros e insuficientes.

Num primeiro momento os que aqui chegavam queriam obter o que não era possível na Europa: ascensão social e riquezas (SAMARA 1999). Para isso, o uso da terra precisava ser otimizado de modo a produzir sempre o máximo possível. Surgem, daí, a maioria dos problemas com a questão da produção de alimentos e subsistência local, primeiramente, nas regiões açucareiras e, depois, no interior.

Isso se tornou tão sério que começou a haver contrabando de produtos alimentares, como aponta SILVA (1994): “Os intermediários tornavam-se cada vez mais necessários, mas até ao fim do período colonial continuaram a ser encarados com suspeição. Eram chamados 'atravessadores', comerciantes que adotaram as várias práticas ilegais associadas com o comércio de abastecimento: açambarcamento [monopolização] dos produtos para forçar a alta dos preços, compra dos mantimentos antes de eles chegarem aos mercados e conspiração para fixação dos preços" (p. 4). 
Para garantir a sobrevivência dos então senhores, escravos e fidalgos foi necessário aprender com o índio alguns de seus "segredos": usar suas rudimentares técnicas de plantio - mesmo que estas estivessem quase 1.000 anos atrasadas em relação a Europa, como apontam LINHARES E SILVA (1981), já que as ferramentas eram caras e raras - apesar dos poucos alimentos que eles mesmos plantavam, e adotar seus alimentos, os quais eram próprios para o clima e solo e que, por sua vez, estavam disponíveis na natureza.

Na caça passaram a apreciar o porco do mato e o porco espinho, que são descritos como de boa carne; comiam também o tatu a paca e o acuti, que era comparado ao coelho europeu. Das aves destacavam-se as pombas, rolas, melros e urús, estes últimos comparados às perdizes européias. Quanto aos peixes foi necessário adaptar o paladar às espécies da região como o peixe boi, que parecia ter gosto de carne bovina e os salmonetes e linguados, que, segundo o cronista, não eram tão bons quanto os da Europa. Muitas frutas que se apresentavam estranhas aos olhos do estrangeiro, como a jaca, o abacaxi e o caju, passaram a fazer parte da mesa colonial.

A substituição dos ingredientes europeus pelos nativos foi um segundo passo nesta adaptação. O cronista SOUSA (1971) sempre empregava em suas descrições frases como "a banana já substituía a maçã européia em tortas e mingaus". A banana acabou assumindo várias preparações como as tortas e mingaus, já mencionados, e para marmeladas, geléias ou mesmo apenas secas ao sol. Era, também, muito importante para tratamento dos doentes. 
Onde a portuguesa usava maçãs, pêras e pêssegos para fazer suas conservas, passou haver mamão verde ${ }^{h}$ e coco. As cerejas e ameixas podiam ter como similar a jabuticaba, e as nozes e amêndoas, o amendoim.

Os alimentos na colônia eram transportados de regiões mais afastadas, que se dedicavam à agricultura de subsistência (SILVA 1994), o que ocasionava situações curiosas: na época de Pombal alguns colonos do litoral tiveram que importar peixe salgado de Portugal, pela insuficiência dos mesmos na colônia (CHAVES 1972). Isso resultava no consumo de alimentos nem sempre bem conservados: carnes, cereais e frutas, muitas vezes, velhos, para não dizer podres e estragados, bastante prejudicados no seu valor nutricional (FREYRE 1963). Apesar das grandes propriedades, o que mais faltava à mesa do senhor de engenho eram exatamente alimentos frescos como frutas, hortaliças, e carnes. Leite e ovos, só se tivessem criação própria.

Mais tarde, pelo menos nos centros urbanos, alguns senhores, que já usavam seus escravos para comercializar produtos, vendiam também algum leite, como pode ser visto nesta gravura de Debret (Figura 43).

LINHARES e SILVA (1981) são enfáticos ao apontar que a agricultura de subsistência era secundária e que só merecia atenção por parte da Coroa quando a falta de gêneros alimentícios significava guerra ou graves problemas políticos e sociais. Quando eram estabelecidos decretos para manter condições mínimas de abastecimento, os senhores de engenho, geralmente, não obedeciam e estavam sempre manifestando sua oposição à legislação que regulamentava o plantio obrigatório de mandioca. Alguns, mais obstinados, para evitarem prejuízo na plantação de cana, optavam por não ter pastos, pois consideravam "cabras e ovelhas criaturas inúteis" e "os

\footnotetext{
h O mamão aparece na lenda descrita por ORNELLAS (1978) e, também, na narração de FREYRE (1963), quanto aos produtos da pequenas lavoura indígena; os demais cronistas, porém, não lhe fazem menção. Entretanto, o doce de mamão verde é um dos mais típicos de Minas Gerais e outras regiōes.
} 
porcos difíceis por se tornarem monteses com o abandono; o gado vacum insuficiente para o serviço dos engenhos, gastos dos açougues e fornecimentos dos navios" (FREYRE 1963, p. 100). SILVA (1994) comenta que, teoricamente, os senhores de engenho tinham que dar a seus escravos terras para plantarem, o que nem sempre acontecia por considerarem isso, também, um desperdício.

Figura 43 - Escravas negras vendedoras de leite

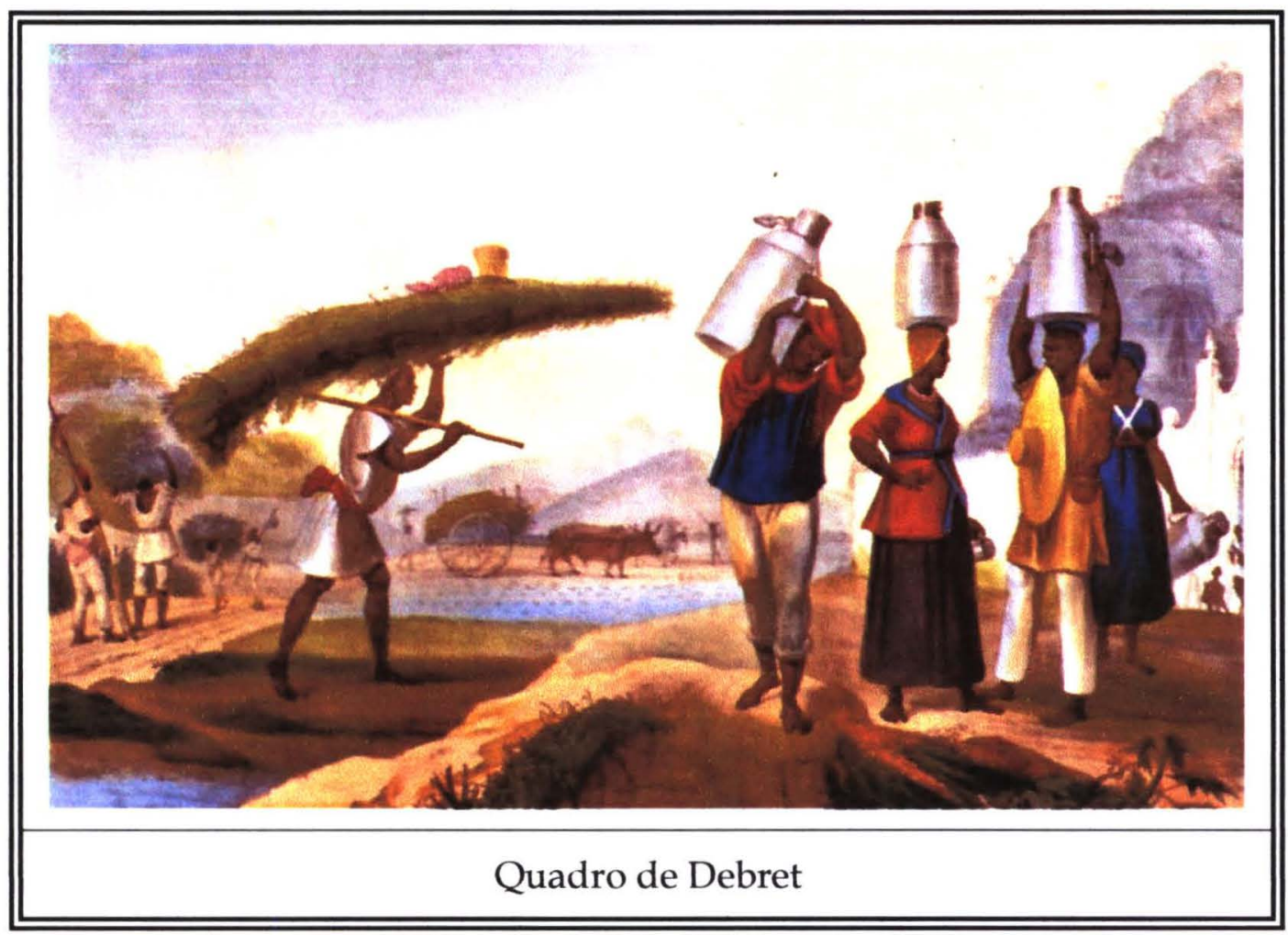

Fonte: EFUSP 1998

Com a queda dos lucros na venda do açúcar o quadro só se agravou pois foi necessário expandir as zonas de plantação da cana. Isso arremetia os poucos recursos de subsistência cada vez para mais longe. Por causa dessas distâncias, o transporte de gado para as regiões mais populosas começou a se tornar mais e mais ineficiente: o gado, que caminhava centenas de 
quilômetros para chegar aos seu destino de abate, perdia peso e, muitas vezes, morria no caminho. Os pastos próximos às cidades não eram suficientes para engordar o gado que era abatido com pouco peso, resultando ainda mais na escassez deste produto (SILVA 1994). Debret registra o momento do transporte da carne dos animais já abatidos na Figura 44.

Figura 44 - Transporte da carne de corte

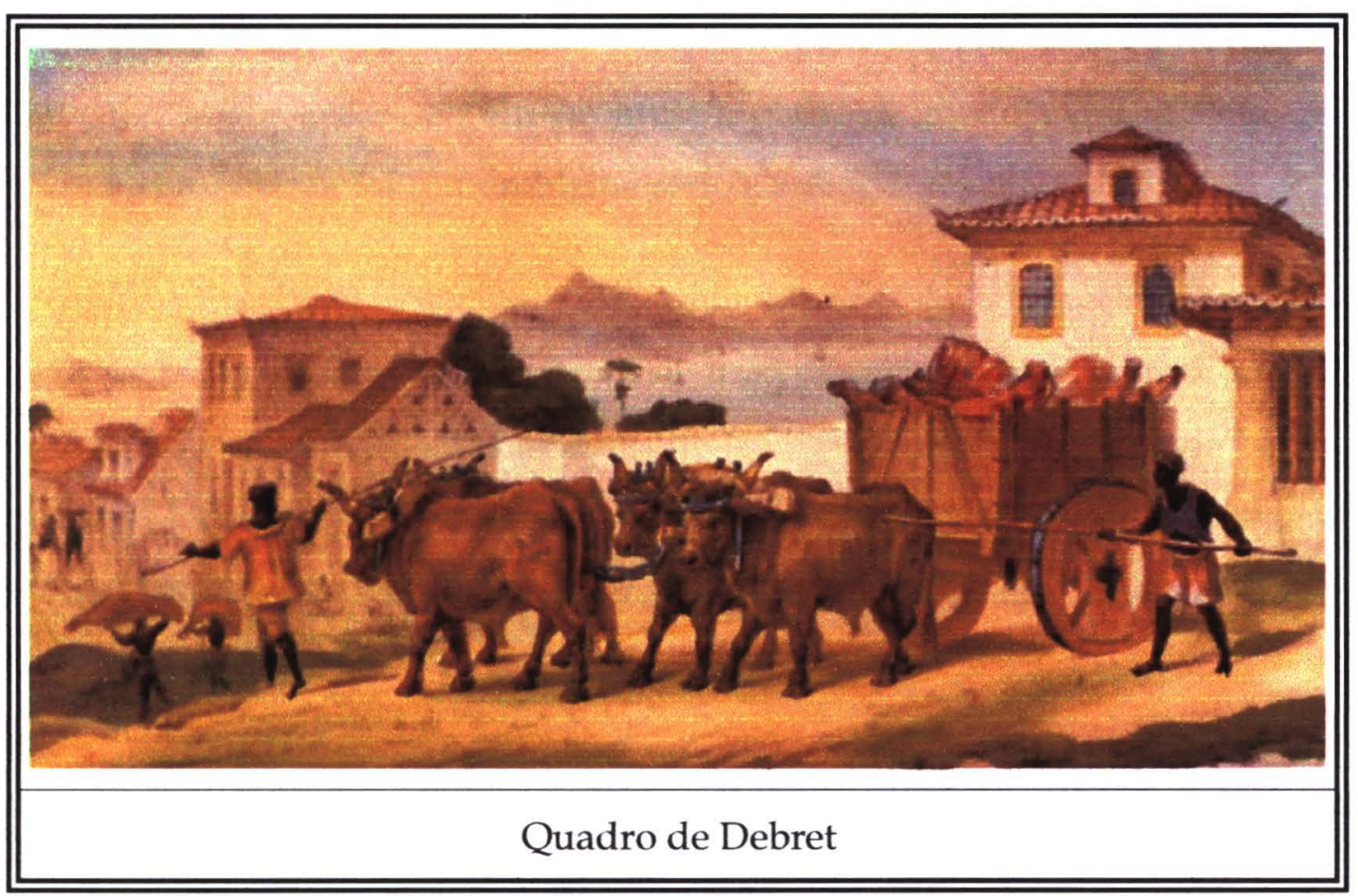

Fonte: EFUSP 1998

A descoberta de ouro no interior da colônia gerou uma verdadeira peregrinação de homens que buscavam conseguir o que não foi possível com o plantio de açúcar. FERLINI (1988) comenta que “...com a descoberta de ouro, levas de brancos marginalizados da grande produção açucareira dirigiam-se para as Gerais." A migração desses homens não melhorou a condição do abastecimento, ao contrário, deslocou a questão da precariedade alimentar individual, da costa para o interior, o que, também, contribuiu 
para a diminuição da produção de certos gêneros, como a farinha de mandioca.

Para superar este e outros problemas criaram-se pequenos centros de comércio que visavam distribuir os gêneros alimentares. Para isso, o gado abatido era salgado para conservação, podendo suportar o tempo do transporte. A presença de carne verde (ou fresca) ficava cada vez mais rara nas mesas coloniais.

As tentativas das câmaras regionais para superar esses problemas alcançavam, por vezes, algum progresso, mais, de modo geral, a falta de alimento na colônia foi um problema sério e crônico.

SILVA (1994) conclui: "As dificuldades de abastecimento que afligiram o Brasil colonial resultaram de uma orientação da economia para a exportação, de comunicações internas de transporte inadequadas e de baixa produtividade da economia doméstica. Os recursos e o capital concentraramse na setor exportador, que era também favorecido pela política governamental" (p. 5).

Olhando-se este cenário, sob outro prisma, entretanto, percebe-se que foi em meio a todo estes acontecimentos que começaram a se destacar nessas duas regiões da colônia algumas características mais marcantes quanto ao modo de cozinhar. A primeira, na casa-grande das regiões açucareiras (parte do nordeste e recôncavo baiano), passou a ser marcada pela culinária africana, já que a escrava negra passou a ocupar, neste momento, também, a posição de cozinheira, e a segunda, mais interiorizada na região das minas, foi fortemente caracterizada pela adaptação dos hábitos portugueses aos recursos e alimentos disponíveis, já que os oriundos de Portugal raramente lá chegavam. 


\section{1 - A INFLUÊNCIA AFRICANA NA COZINHA DAS REGIÕES} AÇUCAREIRAS

A produção de açúcar, o sistema latifundiário e a escravidão negra são apontadas, por alguns autores, como pilastras do sistema colonial no Brasil (PRADO JR. 1965; FERNANDES 1976). A presença do negro nos tempos coloniais, assegurado por este regime, entretanto, acabou ocasionando o aparecimento de uma das cozinhas mais apreciadas no Brasil de hoje: a cozinha baiana, legítima e suprema descendente da afro-brasileira (FREYRE 1963; LIMA 1999a e 1999b; QUERINO 1988). Alguns aspectos curiosos estão relacionados a isso.

Com o passar do tempo os comerciantes de escravos começaram a trazer para o Brasil alguns produtos que consideravam úteis aos seus propósitos. Por volta do século XVII, foi trazida para a colônia uma planta africana, cujo óleo era usado como combustível (BRANDÃO 1948), a qual se aclimatou e logo se espalhou por todo o nordeste da colônia (LIMA 1999a). Esta planta, entretanto, era muito conhecida dos africanos, não para produzir combustível, mas para a culinária; era o azeite-de-dendê.

Ora, o azeite-de-dendê é, talvez, o ingrediente mais importante na culinária dita africana no Brasil. Muitos alimentos africanos tinham seus similares nas terras coloniais, como as pimentas, os inhames, algumas frutas, mas não o dendê. Esse óleo, que dá a comida uma coloração avermelhada, é a marca característica da culinária africana no Brasil.

Daí para frente foi muito simples: as negras e negros que trabalhavam na cozinha dos senhores de engenho só tiveram que adaptar, ao paladar dos senhores, as preparações com pitadas africanas. BRANDÃO (1948) afirma: “Na verdade foi o português, dominador, que levou o negro, cozinheiro, a adaptar ao gosto dos patrões a comida dos deuses africanos. No início da colonização, era o português que cozinhava sua própria comida, no estilı da 
terra natal. Depois a negra cozinheira foi introduzida na casa, passando a servir ao senhor no fogão e também na cama. Com a negra, os ingredientes africanos. E o resultado foi uma comida misto de portuguesa e africana, mais africana porque era a negra que fazia..." (p. 87).

A negra, segundo FREYRE (1963), destinada aos trabalhos domésticos, principalmente na cozinha, tornou-se de certa forma a verdadeira dona da terra. QUERINO (1988), também, comenta: “O português abastado destinava, de preferência, os escravos que adquiria aos trabalhos agrícolas; mas o comerciante, o capitalista, mandava-lhes ensinar as artes mecânicas, reservando sempre um africano ou africana para o serviço culinário, e daí as modificações modernas no arranjo das refeições à moda do Reino, com a carne, peixe, mariscos, aves e animais domésticos" (p. 136). A Figura 45 mostra uma cena de jantar na casa colonial.

Figura 45 - Jantar na casa colonial.

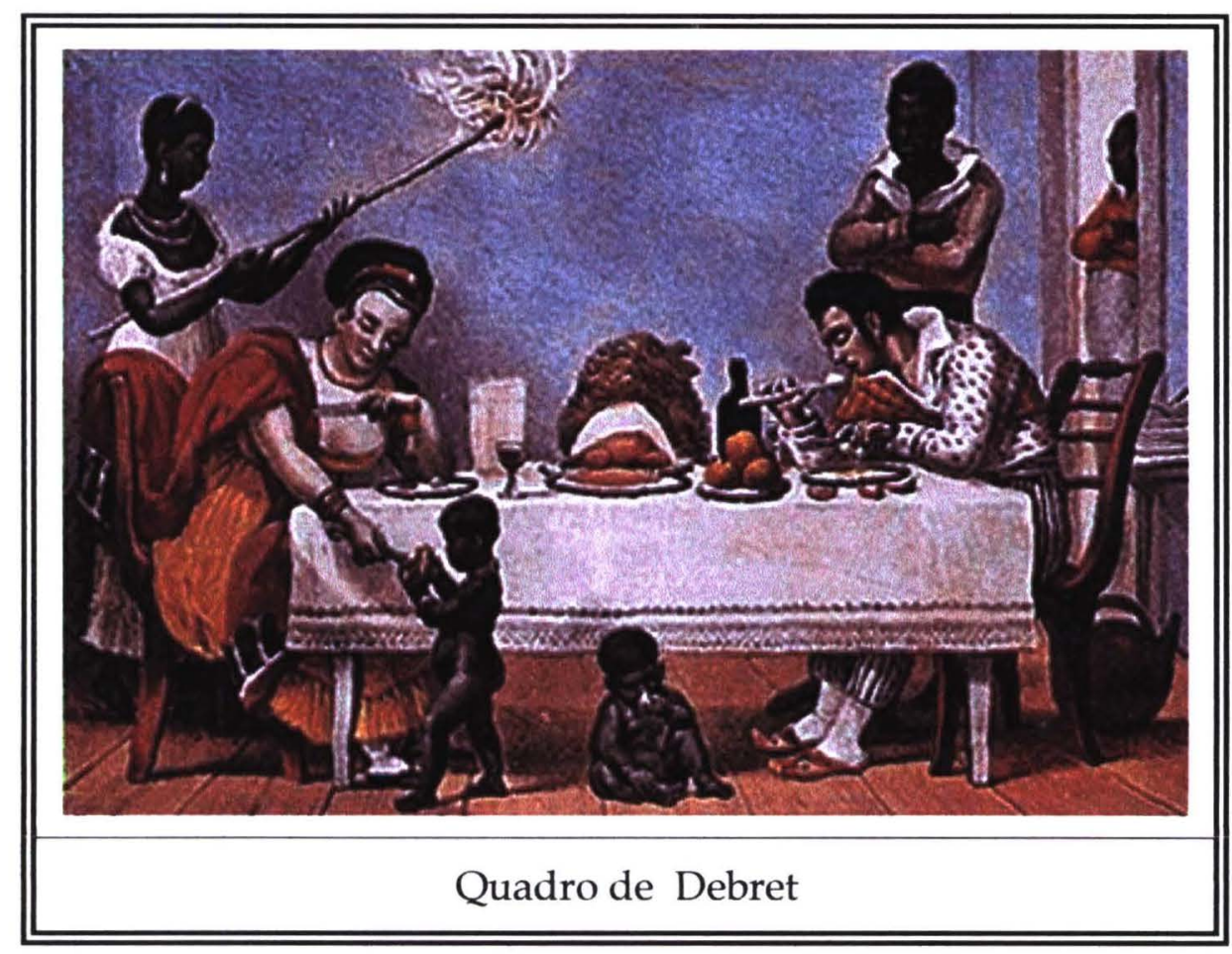

Fonte: EFUSP 1998. 
Seus conhecimentos foram mantidos e praticados através da preparação das refeições, sempre com características africanas. "As iguarias em que o português fazia uso do azeite de oliveira, o africano adicionava, com eficácia, o azeite de dendê, ou de cheiro" (QUERINO 1988, p. 163). LIMA (1999a), também, aponta para este detalhe: "Neste tempo - final do século XVII - foram recriadas muitas das comidas cotidianas dos homens e dos santos. Pois que os santos comem o que os homens comem. E as comidas mais elaboradas das festas, das celebrações votivas. Esse foi o tempo do cozinheiro e da cozinheira escravos, reproduzindo o cardápio basicamente português, mas já substituindo, trocando ingredientes, colorindo ensopados com o vermelho do dendê, inventando as muquecas, usando o inhame, a banana cozida, recriando o caruru, o vatapá. Pratos novos com um sabor antigo que era o deles e um gosto novo que lhes ensinavam..." (p. 322).

A combinação da culinária africana com os alimentos coloniais resultava, nas mãos da negra, em vários sabores novos para as comidas monótonas das casas-grandes. BRANDÃO (1948) dá sua opinião afirmando que a comida de outrora, mesmo a praticada na Europa era insípida e sem gosto. FREYRE (1963), LIMA (1999a) e QUERINO (1988), entre outros grandes admiradores da comida baiana, parecem concordar com essa opinião. QUERINO (1988) chega a mencionar em um de seus textos que em um grande banquete da Société Nationale d'Acclimatation foram servidos timbales de mollusques et de crutaces très appreciés au Brésil, ou seja frigideira de siris moles, além de vatapá. Ele diz que tais quitutes arrancaram unânimes aplausos dos convidados.

Azeite-de-dendê, pimenta malagueta e quiabo são exemplos de produtos comuns na cultura negra e que foram adaptados aos gostos coloniais. A valorização da banana, usada de várias formas, bem como um enriquecimento no preparo da galinha e do peixe são outras contribuições da negra cozinheira. Muitos de seus quitutes passaram a ser vendidos na rua. 
Era comum encontrar as chamadas negras quituteira, como mostram as Figuras 46 e 47.

Figura 46 - Negras vendendo angu

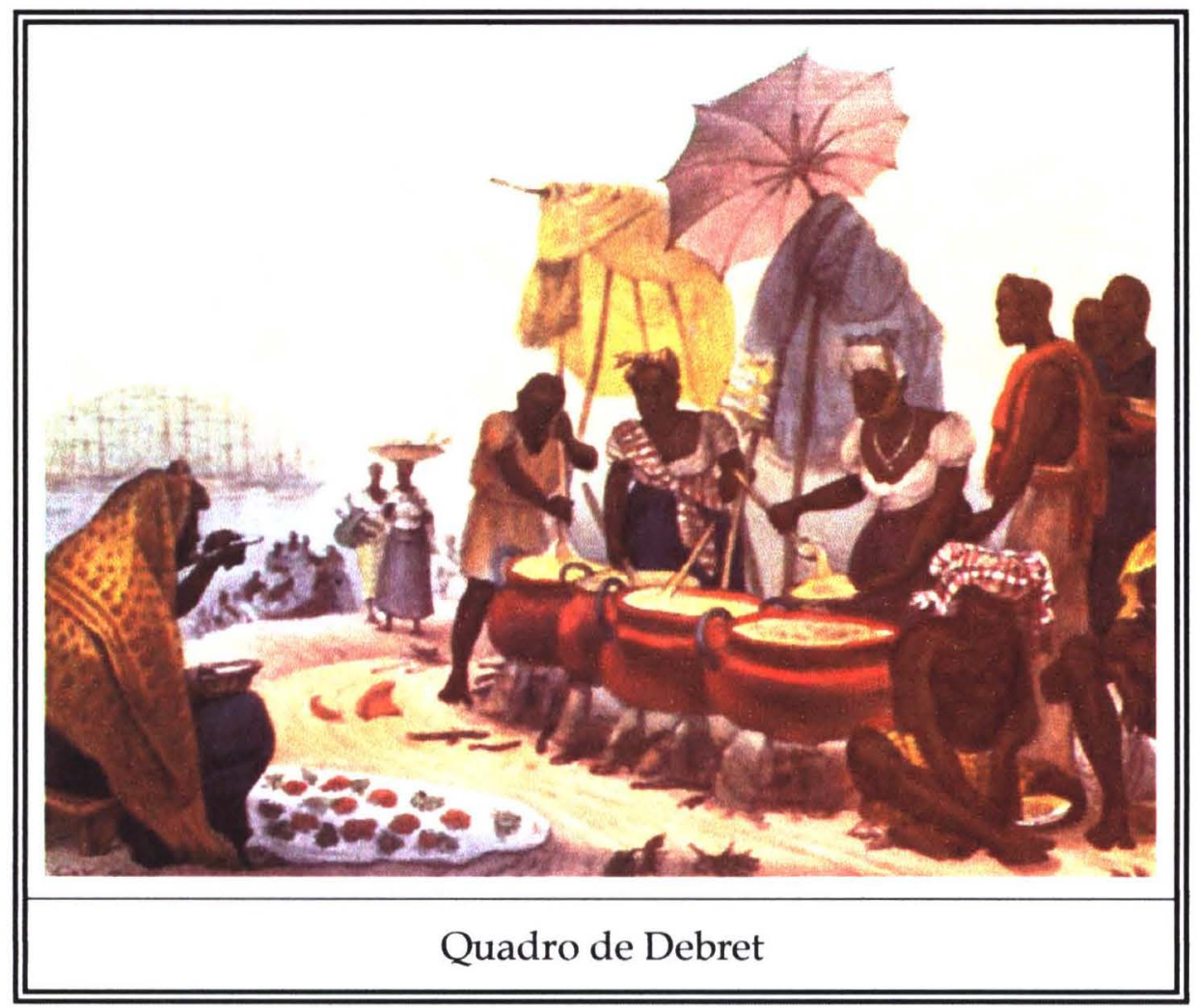

Fonte: EFUSP 1998

Nota-se, neste quadro, que à frente das vendedoras de angu está uma outra negra vendendo um produto que infelizmente não se pode identificar. Poderiam ser ervas ou outra espécie de quitute. Vê-se ao fundo, também, a presença de barcos atracados, o que indicaria um porto. A presença de negras vendendo esta preparação, e na quantidade ilustrada, quatro caldeirões cheios, à beira de um porto, sugere que eram apreciados pelos transeuntes, senão portugueses ou homens brancos, pelo menos outros escravos. 
Figura 47 - Negras vendedoras de quitutes



Fonte: CLIO HISTÓRIA 2001a

Quanto aos utensílios para a preparação dos pratos, a contribuição africana se deu pela colher de pau e pedra de ralar; esta última era usada para triturar facilmente o milho, o feijão e o arroz; media cerca de cinqüenta centímetros de altura (FREYRE 1963).

Dentre as preparações destacam-se farofa, quibebe, vatapá, acassá, manuê, caruru, xinxim de galinha, vatapá e o acarajé. Essas receitas são fortemente condimentadas com pimenta malagueta, cebola, camarão seco e azeite-de-dendê. Muitos destes pratos guardam em sua essência a pura culinária africana, preservada, ainda hoje, em algumas poucas regiões do Brasil, mas principalmente na Bahia. 


\section{2 - A ALIMENTAÇÃO NA REGIÃO DAS MINAS}

A alimentação no Brasil apresentou um desenvolvimento regional, adaptando-se de maneira bastante interessante no que diz respeito à disponibilidade dos alimentos, associando os hábitos dos colonizadores, originários de outros países, principalmente Portugal, aos dos indígenas nativos de cada região, e dos negros, trazidos como escravos.

No caso de Minas este fenômeno ocorreu de forma um pouco diferente, já que sua população se formou a partir da corrida do ouro e outros metais e pedras preciosas. A própria configuração das casas, nas recém criadas cidades, mostram essa condição. Casas pequenas, uma do lado das outra, sem muito espaço; algo mais parecido com as estreitas ruas de Lisboa que com as casas-grandes da região açucareira, geralmente cercadas por quilômetros de plantações de cana. As Figuras 48 e 49 mostram a disposição e composição das cidades de Minas.

Figura 48 - Casa colonial, típica da região das Minas.

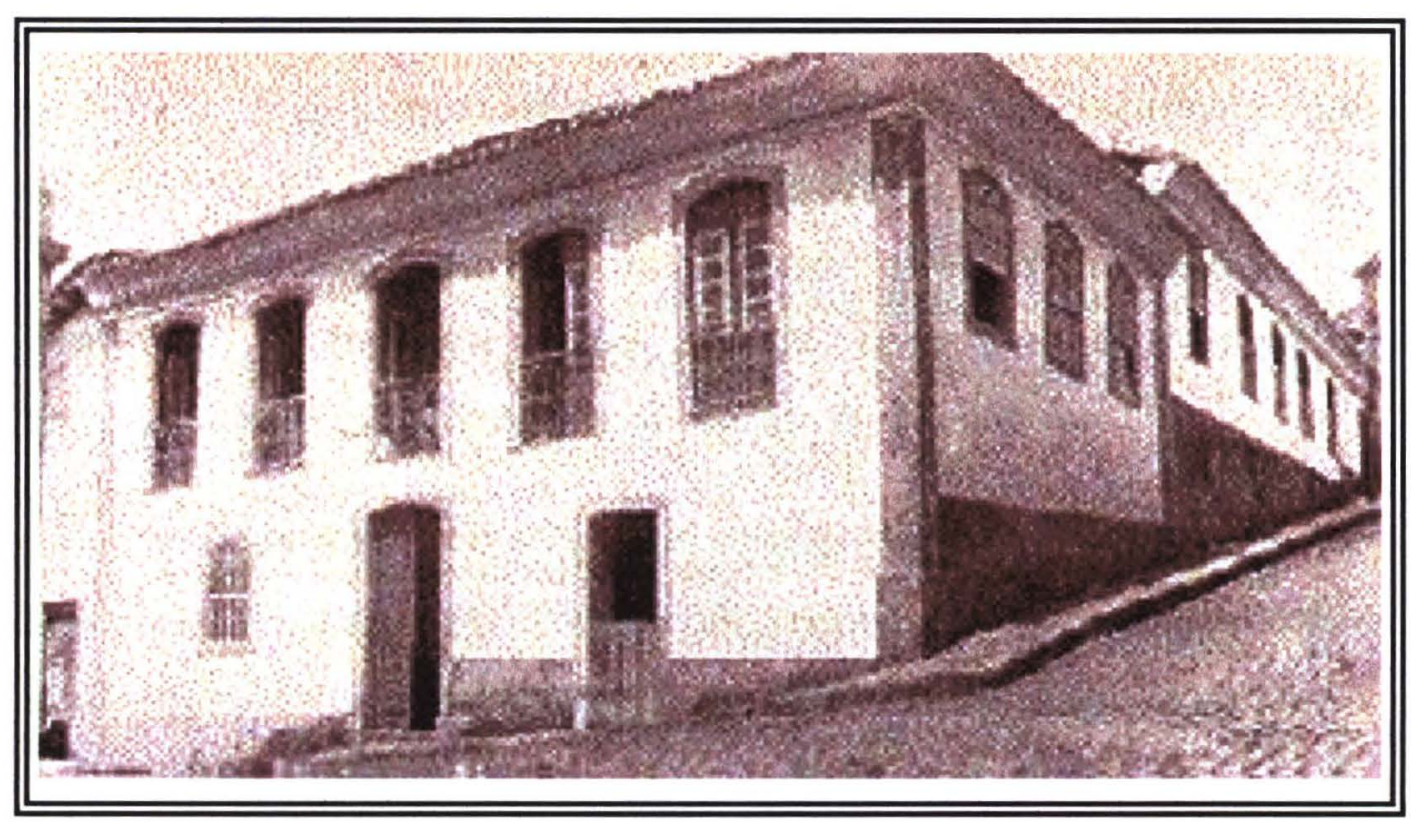

Fonte: MUNDO ANTIGO 2001a. 
Figura 49 - Pequeno núcleo urbano, na região das minas.



Fonte: MUNDO ANTIGO 2001a.

$\mathrm{O}$ número de indivíduos que se dedicavam às expedições para encontrar ouro e pedras preciosas aumentava de maneira inversa ao investimento na agricultura de subsistência. CAMPOS (1983) aponta para o crescimento de uma população de cerca de 100 mil habitantes, em toda a colônia no século XVI, para 3,3 milhões durante o "século de ouro". As Figuras 50 e 51 mostram muitos homens, entre eles escravos negros, trabalhando no garimpo do ouro e na procura de diamantes.

A situação alimentar só piorou com o crescimento astronômico que acontecia nessa região, o que levou muitas regiões de Minas a experimentar uma alimentação muito pobre e deficiente (FRIEIRO 1982), sendo agravado o caso dos escravos, que viviam em condições subumanas. 
Os assaltos às caravanas no caminho, muito freqüentes, geralmente eram cometidos por negros fugidos e criminosos que roubavam tudo o que podiam. Essa atividade fazia lembrar a prática da pirataria, bastante difundida nesta época. Isso, entre outras coisas, ocasionou um choque no abastecimento das cidades do interior, sendo freqüentes a falta de alimentos básicos em muitas delas, como já destacado.

Figura 50 - Escavações para procura de ouro e diamantes.

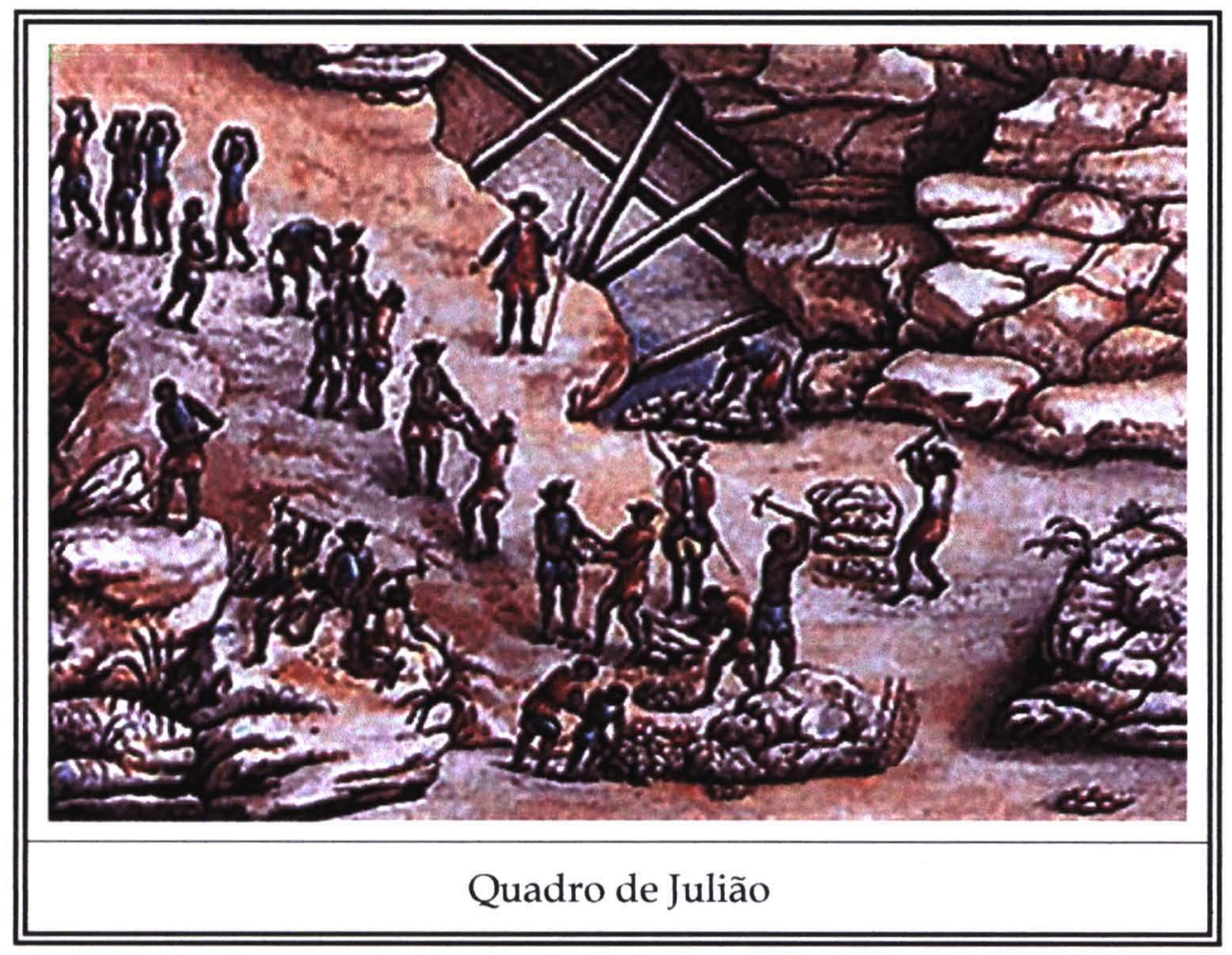

Fonte: CLIO HISTÓRIA 2001a.

Não eram apenas os roubos que diminuíam a oferta de alimentos, mas, também, a falta da agricultura por parte das populações instaladas no interior, ocupadas unicamente em minerar. Essa escassez de alimentos perdurou durante todo o período colonial, tendo sido tão grave que vários 
governadores emprenhavam-se em "incentivar" os lavradores a plantarem, não só a mandioca, mas o feijão e o milho (FRIEIRO 1982).

Figura 51 - A procura de ouro na região das minas.

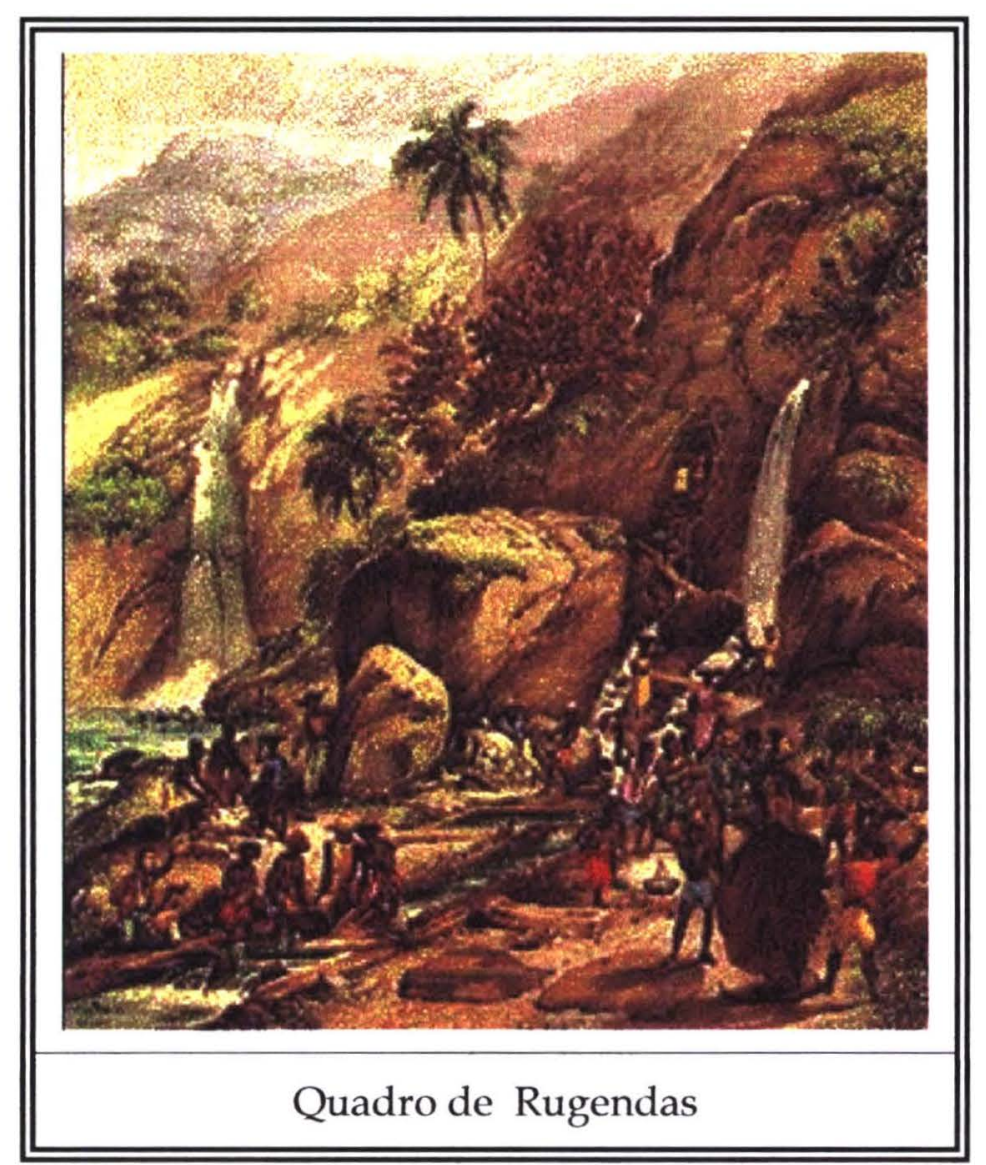

Fonte: CLIO HISTÓRIA 2001b

A necessidade de se alimentar trouxe de volta às narrações históricas outros episódios, bastante comuns para as tripulações dos navios da época: comer o que fosse possível para aplacar a fome. Outros "tipos" de alimentos, presentes no hábito alimentar indígena, foram sendo adotados por muitos. Dentre eles podem-se desatacar três: "bicho-da-taquara", macacos e tanajuras. 
José de Anchieta, descreve o bicho-da-taquara como bichos que nasciam entre as taquaras, roliços e compridos, todos brancos, da grossura do dedo, aos quais os índios chamavam de raú e costumavam comê-los assados ou torrados. Quando encontrados em grandes quantidades, fazia-se um guisado que, segundo seus apreciadores, em nada se diferenciava da carne de porco estufada (FRIEIRO 1982).

A carne de macaco, por outro lado, era considerada pelo padre Anchieta como uma comida muito saudável para doentes.

As formigas tanajuras fêmeas, com seus grossos abdomes cheios de ovos, eram torradas com gordura pelos mineiros. O próprio Monteiro Lobato foi um grande apreciador deste "petisco"(FRIEIRO 1982).

Para os que lá já haviam se instalado, a falta de alimento reavivou um velho costume europeu: o de comer na gaveta. Isso acontecia quando na hora da refeição aparecia algum estranho. $\mathrm{Na}$ verdade, ao contrário do que possa parecer, a intenção era ocultar uma refeição simples e pobre; era um meio de esconder a pobreza da alimentação que desqualificava socialmente os indivíduos. LÉRY (1980), entretanto, aponta outra razão quando comenta “... posso assegurar aos sovinas, e aos avarentos, aos que comem dentro da gaveta, que não serão bem vindos entre os tupinambás, porquanto detestam tal espécie de gente" (p.166). Pode-se sugerir que, para esta época, a generosidade dos índios passou a ser substituída pela avareza dos mineradores.

Em Portugal, por causa da sua estreiteza continental e grande extensão litorânea, ou mesmo durante as viagens marítimas, mantinha-se o hábito de pescar e comer os peixes frescos, o que não acontecia no interior da colônia. Essa alimentação do interior, desprovida de alimentos marinhos, era pobre em alguns nutrientes, principalmente o iodo, o que culminou numa endemia de bócio. $\mathrm{O}$ aparecimento deste sintoma clínico, entretanto, rĩo é 
instantâneo pois o organismo tem capacidade de armazenar iodo por até dois anos e meio. A grande evidência de que esta alimentação era cronicamente desprovida deste nutriente está nos relatos de bebês que já nasciam com esta deformidade (FRIEIRO 1982).

Essa manifestação, entretanto, acabou originando uma situação muito estranha, não apenas pelo seu aspecto clínico, mas, especialmente, pelo social. $\mathrm{O}$ bócio era considerado normal, sendo que em alguns ditos populares se argumentava que a mulher que não tivesse o seu "papinho" não arranjava casamento!

Esses portugueses, radicados às regiões mais centrais da colônia, acabaram apresentando, na obtenção de seus gêneros alimentares, algumas características indígenas. A cozinha passou a compor o prato dos "mineiros" com alimentos resistentes, fáceis de serem cultivados sem muito trabalho na agricultura, além das carnes salgadas. FRIEIRO (1982) descreve esse alimentos:

1. Mandioca - Basicamente na forma de farinha. Era usada em muitos lugares como sucedâneo do pão. Estava sempre presente na mesa colonial e, por diversas vezes, chamada de "pão da terra". FRIEIRO (1982) cita Renato Almeida ${ }^{i}$ para dizer que o mineiro herdou e soube fazer uso de todas as preparações indígenas a base de mandioca: farinha, beiju, biscoito, bolo, mingau, pirão, etc. A Figura 52 mostra o trabalho dos escravos para a produção de farinha de mandioca.

2. Milho - O cereal das Américas. Muita coisa se fazia com o milho: pipoca (grão rebentado ao calor do fogo), curau (mingau doce e duro), pamonhas (doce ou salgada feita com a polpa do milho misturado com leite e cozido em água, geralmente embrulhado na própria palha do milho), farinha

i Renato Almeida, "Manual de Coleta Folclórica, Rio de Janeiro, 1965. 
(normalmente em torrões maiores), cuscuz (mistura da farinha com outros ingredientes, geralmente salgado, cozido), biscoitos, bolos, aluá ou cerveja de milho, aguardente, canjica (milho branco, ou amarelo, cozido geralmente com leite e açúcar) e o importantíssimo fubá (milho seco finamente ralado), com o qual faziam o angu. Sua importância foi anteriormente descrita na pintura de Debret que imortalizou a venda deste produtos por negras escravas.

Figura 52 - Produção de farinha de mandioca pelos escravos.

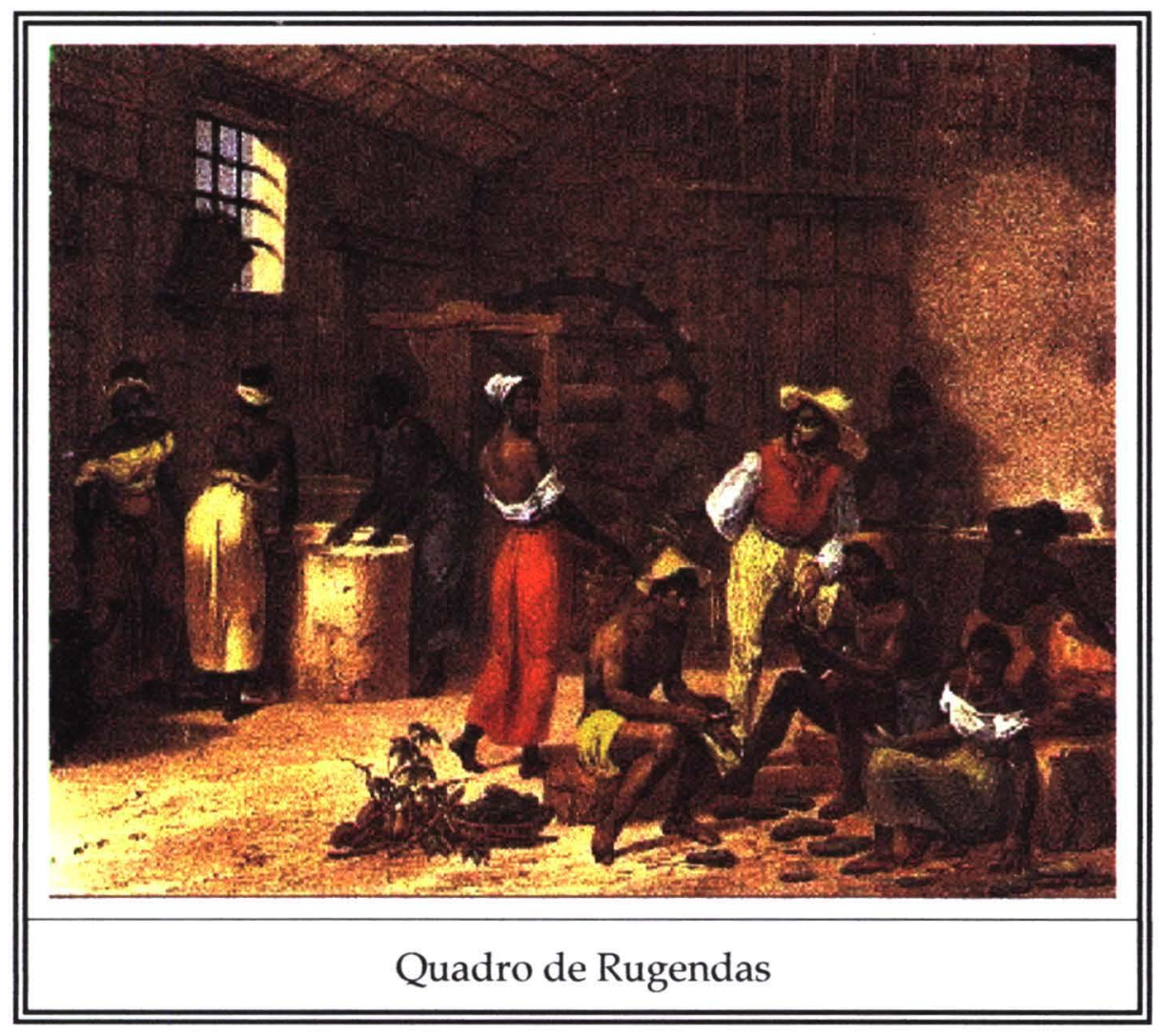

Fonte: CLIO HISTÓRIA 2001b

Este cozido, o angu, representa até hoje um dos pratos mais típicos de Minas Gerais, sendo apreciado de várias maneiras. Para FIREIRO (1982) o 
trio, feijão, angu e couve formam a base da alimentação mineira, tanto que deu a seu livro esse nome.

3. Feijão - é destacado nas narrações o feijão preto. Era preparado com toucinho ou banha de porco. Sobre isso destaca FRIEIRO (1982): “O escravo negro, pau para toda obra, armava o tripé de varas, fincado no chão, e pendurava nele o caldeirão de ferro em que cozinhava o feijão com toucinho..."(p. 57).

Era uma preparação bastante nutritiva rica em carboidratos (amido principalmente), gorduras (bastante energética) e razoável em ferro, representando um bom sucedâneo da carne.

Muitas vezes, o feijão era plantado com o milho nos caminhos para as Minas e, na volta, muito já se podia recolher, garantindo para os mais precavidos, como o próprio Fernão Dias, o sustento do retorno, tão difícil.

4. Carnes secas - Uma das contribuições dos europeus aos hábitos alimentares da colônia foi a salga da carne como método de conservação. É o resultado da exposição da "carne verde" (fresca) ao sal e ao sol. Uma vez que a quantidade de água disponível é diminuída, sua conservação é maior e mais duradoura, podendo ser armazenada por muito tempo.

Era muito difundida e utilizada especialmente a bordo dos navios durante as grandes travessias, até muito tarde no século XVIII. Sem a carne seca o fornecimento de proteínas estaria seriamente comprometido, levando muito mais pessoas à morte do que foi constatado. Esse tipo de carne, como já mencionado, era o mais comum em quase toda a colônia.

O uso de salgar muitas vísceras pode ser explicado pelo ausência de carnes em geral, ou ainda pelo fato de terem adotado o costume indígena de comer todas as partes dos animais. 
5. Couve - com sua folha larga, era consumida refogada só rasgada, pura ou dentro do angu. Parece ser a única verdura apreciada pelos mineiros da época. Hoje, a couve refogada, representa um prato típico de Minas Gerais, conhecido, até, em outros estados como "couve à mineira". As outras verduras não eram consumidas porque pensavam que quem comia "mato" $j$ era coelho. A prática de comer verduras era muito pouco comum, também, em Portugal. As verduras podiam ser vistas como comidas de pobre. E, como se não bastasse, as formigas e outros insetos devastavam as hortas desanimando ainda mais os que se aventuravam a plantar.

6. Cará - muito parecido com a mandioca, difere apenas na consistência, sendo mais pastoso quando cozido. É rico em amido e, por isso, alimento básico para obtenção de energia. Em muitas regiões era sucedâneo do pão. Há uma versão muito popular nesta região que o cará "limpa o sangue" quando se está doente.

7. Abóbora - É um alimento com boas quantidades de vitamina A, talvez, por isso, não se encontrem relatos de cegueira nesta região. Uma vez plantada dá fruto em pouco espaço de tempo, como já destacado anteriormente. Pode ser consumida cozida, em pedaços ou amassada como purê.

8. Café - Consumido durante o dia todo em pequenas "doses", substituiu o leite e mais tarde concorreu com o chá. Nenhum visitante saía de uma casa mineira sem provar do café; caso o convidado rejeitasse a bebida podia ser interpretado como desprezando dos donos da casa, o que era motivo de grande ofensa; o hábito perdura até hoje.

\footnotetext{
; "Mato" era a palavra que popularmente descrevia qualquer vegetal folhoso, muito empregada ainda hoje no vocabulário popular.
} 
9. Laranja e banana - Dentre as frutas consumidas estão, para não fugir à regra, aquelas que mais facilmente se encontravam na região, no caso as laranjas e bananas; as primeiras, comuns em Portugal desde a invasão moura, foram logo trazidas e facilmente se aclimataram; a segunda, como já mencionado anteriormente, estava generosamente distribuída por praticamente todos os locais já habitados da colônia.

Normalmente eram consumidas com farinha, e embaixo do pé onde cresciam. Interessante notar que em algumas citações aparecem referências à alegria de poder se comer "frutas da Europa", como o pêssego, a maçã, etc., dada sua raridade.

10. Cachaça de cana de açúcar - produto bem brasileiro que acabou por substituir os vinho e outras bebidas entre as classes menos favorecidas. Servia para aquecer os dias frios e esquecer a vida muitas vezes bem dura, como já fazia o vinho em Portugal e durante as travessias oceânicas.

Alguns alimentos que poderiam estar disponíveis, não eram consumidos por muitas razões. FRIEIRO (1982) também os cita:

1. Carneiro - O carneiro não era consumido por uma questão bem peculiar: era comparado ao "cordeiro de Deus - Jesus"; não gostavam da idéia.

2. Peixes - Apesar de amplamente consumido em Portugal, os relatos de consumo de peixe na região central são raros. O peixe de rios era considerado como transmissor de lepra.

3. Galinha e ovos - Durante as grandes viagens a galinha era servida como um "bálsamo" para os enfermos, talvez, por isso, não se tinha o hábito de comê-la até que tivessem um convidado ilustre; seus ovos, também, seguiam a mesma regra, sendo mais tarde, ao que parece, destinados a confecção de doces, já que muitos doces mineiros, a exemplo dos doces portugueses 
preparados nos conventos, levavam muitos ovos em suas receitas, como os "Chuviscos" que levam 24 gemas peneiradas!

Outra característica fortemente notada é a falta de interesse pela refeição em muitas regiões; comia-se para se ter a "barriga cheia" e não como algo apreciável. Isso pode ser entendido quando se pensa nas lembranças que os portugueses podiam ter das comidas e alimentos próprios de sua terra, ou porque pela penúria que viviam, perdiam o gosto de pensar em comer (!?).

\section{3 - AlgUMAS HERANÇAS NEGATIVAS PARA A ALIMENTAÇÃO NO BRASIL}

A estrutura do sistema colonial na América portuguesa acabou permitindo que práticas e costumes relacionados a uma má alimentação fizesse parte da vida dos aqui instalados, o que acabou gerando deficiências no modelo alimentar. A convivência com a falta de gêneros em quantidade suficiente para sustentar a população imprimiu como algo normal no dia a dia colonial a carência de alimentos. Não é necessário chamar a atenção para os problemas que isso acarretou: um quadro de subalimentação endêmica em muitas regiões.

Segundo MINAYO e CRUZ NETO (1985), na subalimentação os indivíduos comem menos do que deveriam, o que, ao longo dos anos, lhes confere uma aparência macérrima e envelhecida. Nas crianças, dificulta seu crescimento e desenvolvimento, além de torná-las mais susceptiveis à infecções. Em casos mais graves pode levar a inchaços (por falta de proteínas) alterações neurológicas, cegueira (por falta de vitamina A), anemias, cáries dentárias, enfraquecimento ósseo (por falta de vitamina D), entre outras. 
Determinar as causas deste problema é um assunto que foge à temática deste trabalho. Entretanto, a comparação de textos da época colonial com os da segunda metade do século XX sugerem semelhanças curiosas.

Os critérios de distribuição das terras coloniais, por sesmarias e capitanias hereditárias, por exemplo, garantiam terras a quem tinha condições suficientes para levar adiante $o$ dispendioso processo da colonização (SAMARA 1999). Sobre isso ROMANI (1986) comenta "que a estrutura de posse da terra - entendida como uma conseqüência direta do modelo de desenvolvimento adotado - determina as condições de alimentação das populações e que o aumento progressivo da concentração da terra, nas áreas rurais, conduz a uma situação alimentar cada vez mais deteriorada" (p. 370). Outros autores concordam com essa posição (ABRAMOVAY 1985; LORENA 1985; NASCIMENTO 1985; SACHS 1985; SAMPAIO 1985).

CHONCHOL (1985) e SINGER (1985) são unânimes ao afirmar que grande parte dos problemas de abastecimento passam por questões como queda da produção de produtos básicos, com conseqüente aumento de preços. No contexto colonial essa era uma realidade presente em toda a sua extensão.

LACAZ (1972), citando um trabalho de Nelson Chaves (1964), aponta como causa do desabastecimento, principalmente no nordeste brasileiro, $\mathrm{o}$ crescimento das lavouras de cana. Por causa disso, a alimentação do trabalhador rural tornou-se monótona e constituída basicamente de carne salgada, farinha de mandioca, feijão e açúcar. Ora, não era esse o principal conjunto de alimentos durante todo o período colonial?

LINHARES e SILVA (1981) dizem que a técnica de limpeza da terra pelas queimadas, baseada no costume indígena da coivara, arremetia os agricultores coloniais, em pleno século XVI, para um atraso de quase 1.000 
anos em relação a Europa. O que se dirá de hoje, sabendo-se que em muitas regiões ela ainda perdura? Em uma viagem pelas estradas que cortam zonas agrícolas fatalmente se encontrarão tais queimadas, principalmente nas pequenas propriedades.

Algumas pesquisas mostram que muitos problema alimentares têm raizes de natureza muito mais econômica que cultural. As pessoas não comem bem, não porque não sabem o que é melhor e mais saudável e, sim, porque não têm condições para isso (MINAYO 1985; MINAYO e CRUZ NETO 1985)

Um exemplo concreto está na composição da cesta básica, que não se apresenta como um modelo de alimentação equilibrada, por não conter frutas e verduras, como mostra a Tabela 3.

BARRETTO et al. (1998) fizeram um estudo nutricional desta cesta e constataram pontos importantes.

O aporte energético, por exemplo, supria 71,0\% da RDAk (FNB 1980), o que representou um valor limiar inferior, já que o ideal, preconizado previamente ao estudo, era de no mínimo $70 \%$. As proteínas supriam $97,5 \%$, o que foi considerado muito bom. Foram observados, também, níveis adequados para a vitamina $E$, bem como para tiamina $\left(B_{1}\right)$, niacina, folato $e$ cianocobalamina $\left(B_{12}\right)$. Dentre os minerais, o fósforo $(75,1 \%)$ e o cobre $(74,6 \%)$ colocaram-se em percentuais suficientes.

Por outro lado, verificaram-se carências acentuadas de vitaminas A, C e riboflavina $\left(B_{2}\right), \operatorname{com} 19,9 \%, 15,9 \%$ e $33,8 \%$ da RDA respectivamente e, de forma menos importante, para a piridoxina $\left(B_{6}\right)$. A maioria dos minerais avaliados encontravam-se em índices insatisfatórios, distribuídos em três

k Recemmended Dietary Allowances, 1989. 
níveis: magnésio, zinco e selênio equipararam-se na posição mais favorável, com uma defasagem de pouco mais de 10,0\%; o ferro, cuja taxa obtida foi de $47,6 \%$, mostrou-se em situação intermediária; deficiências severas foram assinaladas para iodo e cálcio. Adicionalmente, constatou-se que a contribuição energética proveniente de lipídios atingia 37,2\%, excedendo os níveis recomendados de até $30 \%$ do valor calórico total.

Tabela 3 - Cesta básica Dieese \& Procon, segundo os produtos e suas quantidades.

\begin{tabular}{lclc}
\hline \multicolumn{1}{c}{ Produtos } & Quantidades & \multicolumn{1}{c}{ Produtos } & Quantidades \\
\hline Arroz & $15,0 \mathrm{Kg}$ & Extrato de tomate & $0,7 \mathrm{Kg}$ \\
Feijão & $4,0 \mathrm{Kg}$ & Óleo de soja & $4,5 \mathrm{~L}$ \\
Açúcar & $10,0 \mathrm{Kg}$ & Leite em pó & $1,5 \mathrm{Kg}$ \\
Café & $1,5 \mathrm{Kg}$ & Macarrão & $2,0 \mathrm{Kg}$ \\
Farinha de trigo & $3,0 \mathrm{Kg}$ & Biscoito maizena & $0,8 \mathrm{Kg}$ \\
Far. de mandioca & $0,5 \mathrm{Kg}$ & Carne de primeira & $3,0 \mathrm{Kg}$ \\
Batata & $4,0 \mathrm{Kg}$ & Carne de segunda & $4,0 \mathrm{Kg}$ \\
Cebola & $1,0 \mathrm{Kg}$ & Frango & $5,0 \mathrm{Kg}$ \\
Alho & $0,2 \mathrm{Kg}$ & Salsicha & $0,5 \mathrm{Kg}$ \\
Ovos & $3,0 \mathrm{Dz}$ & Lingüiça & $0,3 \mathrm{Kg}$ \\
Margarina & $1,0 \mathrm{Kg}$ & Queijo muzzarela & $0,5 \mathrm{Kg}$ \\
\hline
\end{tabular}

Fonte: DIEESE 1994

Com esse dados, pode-se verificar que os alimentos presentes nesta cesta podem induzir a um consumo de grandes quantidades de gordura, o que pode conduzir a enfermidades, principalmente doenças crônico- 
degenerativas. Por outro lado, supre as necessidades imediatas, com respeito ao fornecimento de energia e proteínas, porém, não atende as recomendações para muitos componentes importantes, o que poderia ao longo do tempo resultar em doenças carenciais.

Esta, ao final, pode ser a constatação mais típica do desvio sofrido pelo modelo alimentar no Brasil.

Em uma recente pesquisa do IBGE (2001) ficou constatado que as populações de cidades do nordeste tem um consumo menor de hortaliças (verduras e legumes nesta pesquisa), se comparado às outras regiões. $\mathrm{O}$ quadro abaixo mostra essa comparação.

Figura 53 - Demonstração gráfica do consumo de hortaliças e frutas, em kg por ano, em algumas capitais brasileira, nos anos de 1995/1996.



Fonte: IBGE 2001. 
O baixo consumo em São Paulo, também, poderia estar associado à grande presença de nordestinos na cidade.

Infelizmente, nesta pesquisa, não foram diferenciados os legumes das verduras, o que seria muito mais interessante. Sabe-se hoje que na nomenclatura popular não há distinção entres esses dois termos, o que pode ter dificultado a pesquisa.

Por outro lado, em 1996, o Instituto Brasileiro de Geografia e Estatística, IBGE, constatou que os gastos com alimentação nas maiores capitais brasileiras eram maiores que um salário mínimo, de $R \$ 112,00$ na época, como mostra a Tabela 4.

Tabela 4 - Gastos relativos à compra de itens alimentares, em salários mínimos, nas principais capitais do Brasil, no ano de 1996.

\begin{tabular}{|c|c|c|c|c|c|}
\hline \multirow[b]{2}{*}{$\begin{array}{c}\text { Áreas } \\
\text { pesquisadas }\end{array}$} & \multicolumn{5}{|c|}{ Grupos de despesa } \\
\hline & 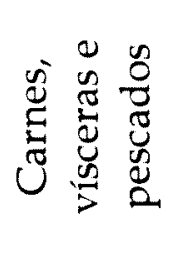 & 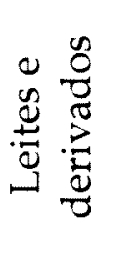 & 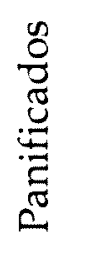 & 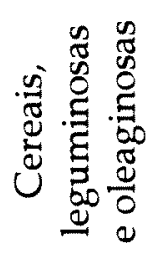 & 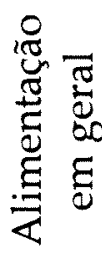 \\
\hline Belém & 0,52 & 0,18 & 0,20 & 0,15 & 1,80 \\
\hline Fortaleza & 0,27 & 0,22 & 0,18 & 0,12 & 1,44 \\
\hline Recife & 0,26 & 0,22 & 0,22 & 0,08 & 1,50 \\
\hline Salvador & 0,32 & 0,22 & 0,23 & 0,09 & 1,54 \\
\hline Belo Horizonte & 0,25 & 0,23 & 0,18 & 0,10 & 1,55 \\
\hline Rio de Janeiro & 0,22 & 0,19 & 0,16 & 0,11 & 1,28 \\
\hline São Paulo & 0,29 & 0,24 & 0,18 & 0,07 & 1,71 \\
\hline Curitiba & 0,28 & 0,24 & 0,18 & 0,08 & 1,69 \\
\hline Porto Alegre & 0,27 & 0,23 & 0,20 & 0,06 & 1,56 \\
\hline Brasília - DF & 0,30 & 0,27 & 0,18 & 0,13 & 1,82 \\
\hline Goiânia & 0,19 & 0,17 & 0,12 & 0,09 & 1,15 \\
\hline TOTAL & 0,27 & 0,22 & 0,18 & 0,09 & 1,55 \\
\hline
\end{tabular}

Fonte: IBGE 2001. 
Em nenhuma capital o gasto médio com a alimentação ficou dentro do valor para um salário mínimo da época, o que leva à conclusão de que, se em alguma família pesquisada houvesse apenas um trabalhador assalariado, recebendo um salário mínimo, esta família não poderia ter nenhuma outra despesa, senão a alimentação e, mesmo assim, não teria em casa todos os produtos que compõem sua alimentação básica.

De novo, as frutas legumes e verduras são suprimidas da pesquisa. $\mathrm{O}$ porquê não foi esclarecido, mas sugere estarem certas as inferências de que não são consideradas tão importantes quanto os demais alimentos.

CASTRO (1937) fez o que se pode chamar de um diagnóstico das características gerais da alimentação regional. Ele apresentou os dados como mostrado na Tabela 5 :

Tabela 5 - Distribuição dos alimentos típicos segundo regiões no Brasil

\begin{tabular}{|c|c|c|c|}
\hline Áreas & Estados e Territórios & Tipos de carência & Alimentos \\
\hline Amazônia & $\mathrm{AM}, \mathrm{PA}, \mathrm{AM}, \mathrm{AC}$ & $\begin{array}{l}\text { Fome } \\
\text { endêmica }\end{array}$ & $\begin{array}{l}\text { Feijão, peixe, rapadura, } \\
\text { farinha de mandinca }\end{array}$ \\
\hline $\begin{array}{l}\text { Nordeste } \\
\text { açucareiro }\end{array}$ & $\begin{array}{l}\text { Litoral e Zona da mata } \\
\text { do Maranhão á Bahia }\end{array}$ & $\begin{array}{l}\text { Fome } \\
\text { endêmica }\end{array}$ & $\begin{array}{l}\text { Aipim, feijão, charque, e } \\
\text { farinha de mandicca }\end{array}$ \\
\hline $\begin{array}{l}\text { Sertão } \\
\text { nordestino }\end{array}$ & $\begin{array}{l}\text { Sertão dos estados do } \\
\text { maranhão à Bahia e o } \\
\text { norte de Goiás }\end{array}$ & $\begin{array}{l}\text { Epidemias de } \\
\text { fome }\end{array}$ & $\begin{array}{l}\text { Milho, feijão, rapadura e } \\
\text { carne }\end{array}$ \\
\hline Centro-oeste & MG, MT e GO & Subnutrição & $\begin{array}{l}\text { Milho, feijāo, carn! e } \\
\text { toucinho }\end{array}$ \\
\hline Extremo sul & Do ES até o RS & Subnutrição & Carne, pão, arroz e batata. \\
\hline
\end{tabular}

Fonte: CASTRO 1937. 
Quanto aos aspectos gerais nota-se que, pela avaliação de CASTRO (1937) nenhuma região brasileira fugiria ao problema alimentar.

Na década de 70, LACAZ (1972) ainda apontava como base da alimentação regional os mesmos elementos apresentados por CASTRO (1937). CHAVES (1972), também, coloca que na região norte, de mais difícil penetração, sobrevive a herança indígena da alimentação, ao passo que em parte do nordeste quem predomina é a africana, ambas heranças do período colonial.

Seria possível dizer que este modelo perde suas forças nas região sudeste e sul somente pela presença dos imigrantes europeus e japoneses, no início do século $X X$, já que estes passam a incluir alimentos estrangeiros e novas técnicas de preparo ao seu cardápio.

As autoridades não estão alheias a esta realidade. Em 1999, o Ministério da Saúde determinou uma série de medidas fundamentais para o setor, prescritas na Política Nacional de Alimentação e Nutrição - PNAN formalmente aprovada pela Portaria 710, publicada no Diário Oficial da União em junho de 2000. A formulação dessa Política Nacional foi coordenada pela Secretaria de Políticas de Saúde - responsável, também, por sua implementação - e contou com a participação de diferentes setores do governo e da sociedade (SPP 2000).

Para o alcance do propósito da PNAN, foram estabelecidas sete diretrizes essenciais:

1. estímulo às ações intersetoriais com vistas ao acesso universal aos alimentos; 
2. garantia da segurançal e da qualidade dos alimentos e da prestação de serviços neste contexto;

3. monitoramento da situação alimentar e nutricional;

4. promoção de práticas alimentares e estilos de vida saudáveis;

5. prevenção e controle dos distúrbios nutricionais e de doenças associadas à alimentação e nutrição;

6. promoção do desenvolvimento de linhas de investigação; e desenvolvimento e capacitação de recursos humanos.

Enfim, para se contornar todos os desvios alimentares observados no Brasil de hoje serão necessários muitos investimentos, mas principalmente na distribuição mais igualitária da produção nacional e no incentivo às pequenas produções locais, de modo a atender, pelo menos, as demandas locais.

\section{4 - CONTRIBUIÇÕES ESTRANGERIAS: AS DUAS VIAS DAS INFLUÊNCIAS ALIMENTARES}

Portugal, durante o período colonial do Brasil, ainda, mantinha contato com várias localidades ao redor do mundo. Seus domínios se estendiam até regiões remotas como o Japão. Esse intercâmbio de experiências, obtidas em terras longínquas, acabou por disseminar por todo império português o uso de alimentos, que em períodos anteriores a essas viagens, estavam restritos aos seus lugares de origem. Pode-se dizer que essa

1 O conceito de segurança alimentar que, anteriormente, era limitado ao abastecimento, na quantidade apropriada, foi ampliado, incorporando também o acesso universal aos alimentos, o aspecto nutricional e, consequentemente, as questões relativas à composição, à qualidade $\mathrm{e}$ ao aproveitamento biológico. $\mathrm{O}$ Brasil adotou esse novo conceito em 1986, com a I Conferência Nacional de Alimentação e Nutrição, consolidando-o a partir da I Conferência Nacional de Segurança Alimentar, em 1994 (SPP 2000). 
influência alimentar ocorreu em todos os sentidos possíveis que combinam América, Ásia e Europa.

Trazidos de além mar, da Ásia e Europa, para as colônias da América poderiam se destacar os vários rebanhos usados nas criações e para os trabalhos, como o de transporte (suínos, ovinos, caprinos, bovinos e eqüinos), além de aves como galinha, pato e faisão; frutas como laranjas, limão, maçã, pêssego, pêra, figo, marmelo, cidra; castanhas como a noz e a amêndoa; legumes e verduras como os brócolos, pepino, rabanete, cenoura, nabo e aspargo; e o costume de tomar leite e fazer queijo. Da Ásia foram ainda trazidas muitas espécies de flores, como lírios, crisântemos, camélias entre outras plantas (FRANCO 1986), além do importantíssimo café.

Um pequeno destaque para este último. Segundo MACHADO (1984), o café é o fruto da Coffea arabica, uma planta originária das montanhas da Abissínia (Etiópia), onde nascia e crescia naturalmente. LEMPS (1998) diz que foi levado para a Arábia onde uma preparação rudimentar passou a ser consumida: os grãos do café eram torrados e fervidos em água. No século XV já existiam em Meca vários estabelecimentos onde o café, deste modo, era servido. Sua disseminação passou pelo Cairo e alcançou Constantinopla, no Oriente Médio. Os comerciantes venezianos o levaram para a Itália, onde a preparação ganharia sua forma definitiva. Os italianos não gostavam de comer a borra do café turco; pensaram que talvez fosse possível separá-la, por meio de um tecido ou filtro; nascia o coador de café. Daí para frente, na forma de bebida revigorante, ganhou o mundo.

Essa bebida quente, à qual agora se adicionava o açúcar, vindo das Américas, extrapolou sua função alimentar e ganhou uma importante face sociológica. O café passou a ser apreciado em conversas que ganharam, em toda a Europa, lugares para se realizarem. Surgiam os Cafés. Lá atores e escritores discutiam suas idéias, transformando esses pequenos 
estabelecimentos em verdadeiros salões literários. O próprio Voltaire era freqüentador de Cafés. Na Inglaterra os Coffe Houses surgiram em 1652, mas em 1676 o procurador-geral da cidade mandou fechá-los porque tornaram-se espaços de contestação política. Não tardou a revogação de tal medida, o que garantiu a prosperidade destes estabelecimentos. E prosperavam em toda Europa.

Portugal foi um dos últimos países a adquirir o hábito de tomar café, o que aconteceu só no começo do século XIX. Lá os Cafés foram chamados de Butequins, como destaca MACHADO (1984). Infelizmente não se precisou a época que o café entrou na colônia. MACHADO (1984) só menciona que antes do século XIX as sementes do café haviam sido levadas para a América do Sul, que mais tarde se constituiu um excelente produtor.

A presença do café na colônia transformaria o Brasil em um dos países que mais consomem café no mundo, além de ter um importante papel social, pois, como foi mencionado, oferecer café aos visitantes e convidados é um dos costumes de hospitalidade mais difundidos no Brasil de hoje. Após grande jantares ele, também, é servido, e bem aceito.

Apesar de ter sido responsabilizado por muitos males à saúde, ele reina, inabalável, na casa de milhões de brasileiros.

Por outro lado, não foi apenas nas colônias que se sentiram os ares das influências externas. O caminho oposto, basicamente representado pela saída de produtos americanos para outras partes do mundo, também aconteceu. A capacidade empreendedora do comerciante europeu da época (ou mais especificamente, portugueses e espanhóis) permitiu que muitos alimentos fossem levados para a Europa e Ásia, o que permitiu, mais tarde, que muitos deles se tornassem elementos básicos das cozinhas locais. Dão-se destaque para o milho, batata-doce, os quais tiveram fácil aceitação em várias partes da Ásia (MACHADO 1984), além do tomate (que seria do mundo moterno 
sem o tomate?), mandioca, quiabo, pimentão, abacaxi, goiaba, mamão e tabaco. Contudo, dentre todos os alimentos oriundos das terras americanas, os mais importantes, talvez, sejam a batata e o cacau.

A batata, ou Solanum tuberosum, foi primeiramente identificada na região que hoje corresponde ao Peru, como planta expontânea e que já servia de alimento aos incas (MACHADO 1984). Por suas características incomuns, foi levada a Europa por comerciantes e exploradores, representando, mais tarde, um dos alimentos mais importantes de algumas regiões, principalmente em épocas de desabastecimento e guerras. MACHADO (1984) faz narrações interessantes da saga que teve a batata até ser, realmente, considerada um alimento importante.

Segundo ele, durante os séculos XVI e XVII, muitos países mantinham experiências de cultivo com diversas variedades da planta para consumo humano, já que, até ali, os resultados eram insatisfatórios. Apenas no século XVIII é que os alemães conseguiram obter uma batata de sabor realmente agradável, um pouco antes da "Guerra dos Sete Anos". Com a guerra, a fome seria inevitável. Mas desta vez, esse novo alimento passou a ocupar as vazias mesas nas cidades prussianas, bem como, alimentar as tropas envolvidas na guerra.

Um evento curioso ocorre. Um agrônomo francês chamado Parmentier, foi capturado e mantido prisioneiro durante esta guerra. Neste período, ele pode verificar como os alemães lidavam com as novas variedades da batatateira, obtendo seus importantes tubérculos. De volta à França, em 1764, depois da guerra, ele se torna um divulgador destes conhecimentos, chamando a atenção do Rei Luís XVI. Obviamente, havia aqueles que se opunham dizendo, até, que a batata produzia lepra. Certa manhã, entretanto, ele verificou que suas batatas, às quais tinha cultivado com tanto cuidado, haviam sido roubadas. Consolou-se pensando que os 
ladrões podiam tê-las achado alimentares e saborosas... O que ele talvez não soubesse é que, por sua campanha, a batata se tornaria realmente popular em toda a Europa, evitando que a fome voltasse a tomar as proporções já conhecidas.

Em Portugal, por outro lado, só haveria um aumento significativo no consumo da batata em meados do século XIX, quando o aumento populacional revelaria, de novo, deficiências no abastecimento. Por ser um alimento que fornece boas quantidades de calorias, ser barato, de fácil digestão, estar apto para ser colhido em 100 dias e, talvez, o mais importante para esta época, ter um rendimento excepcional (pois, cada tonelada plantada podia render até 25 toneladas), a batata marcou definitivamente sua inclusão na dieta portuguesa.

Hoje em dia não se pode pensar em alimentação na Europa sem a presença da batata no cardápio.

O cacau, à semelhança da batata, tem uma história recheada de curiosidades. Sua "descoberta" também se deve aos exploradores espanhóis, que perceberam nos rituais aztecas a presença de um líquido muito estranho que os índios bebiam, o xocoatl (FRANCO 1986). Estava presente, também, em banquetes do rei Monctezuma, de Tenochtitlan (futura Cidade do México).

Segundo LEMPS (1998), esse xocoalt era assim obtido: as sementes do cacau forneciam uma espécie de manteiga, à qual os índios acrescentavam pimentão e urucum, e algumas vezes, milho verde, frutas, e até cogumelos alucinógenos. Tudo era fervido e mexido vigorosamente até obter-se a consistência desejada. Não é necessário dizer que os espanhóis acharam horrível tal mistura. Em 1589, Acosta escreveu: "O cacau utiliza-se, principalmente, numa beberagem chamada de chocolate à qual é dada muita importância nesta terra, embora os que não têm estômago para isso sintam 
nojo porque, na superfície, forma-se uma espuma e efervescência muito pouco atraentes à vista, de tal modo que é necessária muita coragem para evitar essa impressão. Mas, enfim, é a bebida preferida; além disso, os índios e espanhóis oferecem-na aos hóspedes mais importantes..." (p. 614)

Felizmente, mais tarde, alguém teve a idéia de misturar açúcar ao invés de pimentão. Segundo a tradição mexicana, religiosos instalados em Oaxaca desejaram realizar essa substituição. O porquê pode ser óbvio, mas não é mencionado. Alguns sugerem que pela grande disseminação do açúcar, adicioná-lo às bebidas passou a ser comum, principalmente nos licores e vinhos. A adição do açúcar ao chocolate seria apenas a extensão de tal hábito.

De fato, o adoçamento da bebida garantiu-lhe o sucesso, de modo que, já no final do século XVI, era moda na Espanha tomar-se chocolate no lanche. A produção de cacau passou a ficar insuficiente para o mercado espanhol, $o$ que forçou a expansão de sua produção para outras terras.

Passou a ser consumido sucessivamente em outras regiões da Europa, a começar na Itália, Alemanha, Holanda e, por fim, Inglaterra. Na França sua introdução foi atribuída a Maria Teresa, da aristocracia espanhola, por ocasião de seu casamento com Luís XIV, em 1660. Até o final do século estariam espalhadas ao longo do Sena pequenos comércios que vendiam a bebida.

Sua obtenção começava a ser melhorada e, já, em 1728, começou-se a usar a prensa hidráulica. Em 1770 já havia na França algumas indústrias chocolateiras. Mas foi 1828 que o holandês Conrad Van Houten conseguiu separar a manteiga do cacau, o que melhorou, em muito, a qualidade do novo chocolate comercializado. A combinação de todos esses fatores culminaram, nesta época, no surgimento de uma grande variedade de indústrias, entre elas a Nestlé, que passaram a comercializá-lo na forma de 
barras. Como LEMPS (1998) conclui, a produção mundial deu um grande salto e passou de 10 mil toneladas, em 1830, para 2 milhões de toneladas por volta de 1999! 


\section{5 - COMENTÁRIOS FINAIS}

A despeito da falta de interesse por parte da maioria dos historiadores e profissionais da saúde ligados à Nutrição, a história da alimentação é um tema apaixonante e que revela facetas, muitas vezes ignoradas, $\mathrm{du}$ complexidade que se apresenta o hábito alimentar de um povo.

Viagens, comércios, explorações e conquistas, são todos elementos disseminadores de hábitos e costumes. A própria globalização, palavra tão presente no vocabulário moderno, já é uma prática muito mais antiga do alguns imaginam, estando presente, de fato, em toda a história da humanidade.

Com a alimentação não foi diferente. Todos os grandes fatos históricos apresentam paralelamente, e de maneira menos abordada, eventos ligados à alimentação. Sua abundância, falta, cultivo e preparação estão, de alguma maneira, sempre ligados à história; daí a importância que este saber tem adquirido junto aos pesquisadores da Nutrição.

Por outro lado, a própria história tem sido testemunha de que muitos tem considerado os atuais conhecimentos como verdadeiros salvadores do organismo. Daí surgem neste coletivo, talvez inconscientemente, lemas como "temos que ensinar as pessoas o que comer". A alimentação passou a ser vista em termos de macro e micronutrientes, sendo este mesmo o discurso de muitos especialistas: "Você precisa comer mais proteínas!". Mas o que é comer proteína?

Alimentos, praticamente mágicos, começaram a ganhar importância na mídia: a soja, a beringela, etc. Outros, por sua vez, passaram a ser acusados de danosos à saúde, como as carnes vermelhas, ou ovos, pelo alto teor de colesterol. A moda passou a ser a preocupação com o coraçã : e as 
doenças degenerativas, como aterosclerose, diabetes, etc. As indicações e prescrições de exercícios físicos, associados a toda esta "caça aos alimentos", deram origem a uma nova geração de indivíduos, muitas vezes, obcecados por essas práticas. Isso tem seu motivo. As doenças do aparelho circulatório são a principal causa direta de morte, no Brasil, nos últimos 5 anos, chegando a quase $25 \%$ das causas totais de morte (IBGE 2001). É um quadro muito sério.

Mas a melhor maneira de contornar o problema é adotando medidas como há pouco apresentadas? Em muitos casos não, principalmente, quando as informações transmitidas não são bem assimiladas pelos ouvintes e geram nas pessoas tamanha ansiedade, que acabam despertando o que poderia ser a outra face da moeda: pessoas obcecadas pela boa forma física, depressão em parte da população feminina, por não conseguirem alcançar os ideais de beleza preconizados na mídia, ou ainda, a ruptura de bons hábitos que foram passados de geração a geração, como o uso de determinadas ervas para fins diversos, entre outros.

Esse atendimento à saúde está doente: grande parte do sistema está voltada a tratar de problemas já instalados ao invés de priorizar a prevenção. A falta de preparo por parte dos profissionais, já que os mesmos estão voltados a um atendimento rápido, além da distância entre as partes envolvidas, faz da idéia de conversar e trocar experiências, profissionais e pacientes, algo utópico e distante da realidade.

As orientações de saúde são massificadas e não levam em conta a rica experiência que cada indivíduo pode ter, o que ele pode dar em contribuição, por mínimo que seja.

FRIEIRO, no $2^{\circ}$ tópico de suas considerações preliminares - "Diálogo com um nutricionista" - faz considerações que são extremamente 
importantes para aqueles que consideram que os conhecimentos modernos salvaram a humanidade de erros quanto à sua alimentação.

$O$ que aconteceu, pergunta FRIEIRO de maneira indireta, com a sabedoria do homem que lhe permitiu sobreviver durante esses milhares de anos sobre a Terra? Ou ainda, no que se transformará a cozinha (entenda-se aqui a dieta habitual de cada indivíduo ou das coletividades) se todos resolverem seguir à risca essas recomendações?

Seria verdade que o homem não sabe se alimentar? O que dizer dos animais que, instintivamente, aprendem qual a erva comestível e qual a venenosa? Como sabem os pássaros que as rãs amarelas e vermelhas são perigosas? Seria o homem menos capacitado a tal tarefa que simples pássaros e mamíferos?

A resposta que se poderia dar a FRIEIRO, ou a qualquer outro indivíduo que não simpatizem com os nutricionistas e médicos (como tanto se tem encontrado ao longo da realização de um trabalho como este), é que o homem não é menos capacitado para esta tarefa, apenas perdeu, ao longo da história, esse conhecimento, pela intervenção de fatores variados.

Por exemplo, há cerca de 600 anos comer açúcar era um privilégio inigualável, uma iguaria. E o que se pode dizer de hoje? Certamente não é assim. Qualquer pessoa pode ter em casa um quilo de açúcar; a história do Brasil proporcionou que isso fosse, ainda, mais forte, uma vez que, durante muitos anos do período colonial, foi o maior exportador mundial de açúcar. Isso se apresenta como uma explicação razoável para o gosto do brasileiro, apreciador de preparações bem doces, quando comparados aos do europeu ou asiáticos. Mas isso é saudável? E a resposta seria não; mas não, principalmente, ao se observar o estilo de vida moderno, preenchido por horas de trabalhos sedentários, quando se olha para as sociedades urbanizadas e não, também, quando o açúcar é um dos compor ntes 
alimentares mais importantes na família, dado o fato que contribui com calorias, mas nenhum outro nutriente, o que gera doenças carenciais, algumas bastante severas.

Este "novo" componente da dieta, praticamente ausente durante séculos, surgiu e foi adotado na alimentação. Este e tantos outros, frutos da modernização do mundo, dos artifícios de conservação, dos nitritos e nitratos, antiumectantes, agrotóxicos, pesticidas e tantos outros, que possibilitaram prolongar a vida útil de muitos alimentos. Não se deve negar seu valor. Eles possibilitaram que milhares de pessoas se alimentassem. E isso traz à lembrança alguns estudiosos, que diziam ser a produção de alimentos de escala aritmética e a da multiplicação de indivíduos no planeta, de natureza geométrica. A primeira se soma, 2, 4, 6, 8, 10, 12, etc., mas a segunda se multiplica, 2, 4, 8, 16, 32, 64. Eles tinham razão em se alarmar ao considerar tal informação. Em pouco tempo não haveria alimento para todas as pessoas da Terra. Não. Não se deve menosprezar o papel que esses componentes tiveram na alimentação, principalmente nos últimos 20 anos.

Mas, ao longo do trabalho, foi possível observar que muitos alimentos novos foram introduzidos na alimentação; outros por sua vez, foram tirados. Algumas dessas mudanças foram benéficas, mas outras, nem tanto.

O conhecimento ligado à alimentação, legado de milhares de anos de história do homem, deixou de ser passado de pai para filho; foi substituído pelo instinto maior, o da sobrevivência. Por muitas vezes, deixou-se de comer o que era de costume, para aplacar a fome com o que estava disponivel. E por quê?

No caso da colônia portuguesa na América, muitas dessas restrições não estavam ligadas ao que o homem já estava acostumado, como, por exemplo, catástrofes naturais; tiveram suas raízes em questões econômicas e políticas, como em muitos outras partes da América do Sul. Grande parte 
desses países, ditos em desenvolvimento, experimentaram a limitação e perda (para não dizer roubo) do conhecimento alimentar que havia sido adquirido por anos de história. Muitos pais já não ensinavam a seus filhos o que deveriam comer, porque eles, também, já não sabiam mais.

Talvez, por conseqüência disso, é que, principalmente nas comunidades urbanas das grandes cidades, a maioria dos pais está muito mais envolvida com o "ganha pão" que com a educação alimentar. Esta, enfim, acaba sendo relegada às escolas ou mesmo à televisão, que ao final, não tem muito a dizer.

Hoje em dia, frente a todo conhecimento, científico, o problema alimentar se divide: Por um lado estão aqueles que poderiam comer satisfatoriamente, e não o fazem por falta de conhecimento, (não considerando o caso de pessoas que necessitam de dietas especiais por motivos de saúde) entre outras razões, e, por outro, aqueles que não tem acesso aos alimentos, ou condições de adquiri-los, sofrendo as penúrias da subalimentação e fome.

Quanto a este segundo aspecto, caberia às autoridades competentes desenvolver e aplicar políticas alimentares, de modo a padronizar, dentro da população, esse acesso e a possibilidade de aquisição dos gêneros alimentares que lhes permita uma vida saudável, incluindo-os no primeiro aspecto apresentado.

Quanto a aquele primeiro, tem-se feito grandes progressos no sentido de orientar os indivíduos, ou seja, dar a eles um conhecimento que permita a autonomia para escolha dos alimentos que melhor lhes convenha, de modo que seja possível associar saúde e bem estar. 
Recentemente tem-se usado o que os profissionais chamam de guias alimentares. Já não se diz exatamente o que uma pessoa deve comer. Ela deve saber escolher. A Figura 54 mostra um destes guias.

Figura 54 - Guia alimentar, segundo grupo de alimentos e recomendações diárias.

\begin{tabular}{|c|c|}
\hline Grupos de Alimentos & $\begin{array}{l}\text { Quantidades de porções } \\
\text { recomendadas/dia }\end{array}$ \\
\hline Grupo 1 - dos cereais, pães e massas. & $6-11$ \\
\hline Grupo 2 - das verduras e legumes & $3-5$ \\
\hline Grupo 3 - das frutas & $2-4$ \\
\hline Grupo 4 - do leite, queijos e iogurtes & $2-3$ \\
\hline Grupo 5 - das carnes, feijões, nozes e ovos & $2-3$ \\
\hline Grupo 6 - das gorduras e açúcares & moderado \\
\hline $\begin{aligned} \text { Grupo } 7 \text { - dos outros (que inclui } \\
\text { refrigerantes, café preparado, } \\
\text { chá, sal, mostarda, catchup, etc. }\end{aligned}$ & moderado \\
\hline
\end{tabular}

Fonte: BERTOLINI 1996.

Esses grupos foram elaborados com base nos principais nutrientes que cada alimento pode fornecer. O grupo 4, por exemplo, está relacionado principalmente ao cálcio. O grupo 5, com o ferro e as proteínas de alto valor biológico, e assim por diante.

De modo geral, sabe-se que se um indivíduo consumir, por exemplo, em uma semana, uma média semelhante ao que está recomendado, estaria fazendo uma boa alimentação. Paralelamente, recomenda-se que haja 
variedade quanto aos alimentos consumidos, de modo que se alcance, realmente, a ingestão de todos os nutrientes necessários a uma boa saúde. BERTOLINI (1996) demonstra isso numa avaliação nutricional que fez em uma refeição padronizada, que seguia este guia. Os resultados foram refeições equilibradas e que supriam plenamente as recomendações gerais.

Assim sendo, se em um dia o indivíduo consumiu muitos alimentos do grupo de carnes e menos das frutas, poderá inverter as quantidades no dia seguinte, desenvolvendo uma "compensação" que resultará, ao final do período de uma semana, numa dieta equilibrada, pela média dos dias.

Estas são medidas sensatas e que permitem aos indivíduos incorporar, em seus próprios hábitos alimentares, práticas mais saudáveis que, se fossem mais divulgadas e recebidas, gerariam uma população mais livre de doenças; não exporia muitos indivíduos à prática de dietas malucas que prometem milagres, além do uso de muitos medicamentos prescritos por médicos que desconhecem os históricos de vida individual e que cedem aos interesses de seus clientes, quando querem emagrecer rapidamente.

Volta-se, neste ponto, à introdução deste trabalho que aponta para a necessidade de praticar atividades físicas e devolver ao organismo aquilo para o qual ele se desenvolveu: um estilo de vida saudável, com esforços suficientes para manter suas capacidades fisiológicas, através de atividades físicas regulares e do suprimento adequado de combustível (caloria dos alimentos) e outros elementos relacionados (vitaminas, minerais e água).

O que o conhecer a história alimentar de um povo tem haver com tudo isso? A resposta, apesar de simples e importante, é ignorada por muitos.

Ao longo do trabalho foram sendo apresentados eventos históricos que se relacionavam, de alguma maneira, com o modo de comer no Brasil. Começou-se destacando as remotas práticas alimentares, ainda na Europa 
Medieval, para mostrar que os portugueses, principais colonizadores do Brasil, tinham virtudes e deficiências, e que muitas delas foram "exportadas" para a colônia.

Já na colônia foram enumeradas as dificuldades iniciais relacionadas à fixação do colonizador; com elas algumas das providências tomadas. Terminou-se com ponderações relacionadas às causas de um sistema alimentar desfavorável e deficiente em muitos de seus elos. Todos esses eventos, entretanto, revelam características que definem como foi a alimentação no período colonial, algumas boas, outras, nem tanto.

A atenção dos primeiros portugueses estava desviada para valores que não estavam relacionadas à alimentação, o que gerou uma situação de dificuldades, como já apresentado. Porém, o que se deve destacar foi a capacidade que tais indivíduos tiveram para superar essas dificuldades.

Primeiramente adotaram hábitos indígenas: seu modo de plantar, seus alimentos e muitas técnicas de conservação e preparo dos alimentos. Posteriormente, adaptaram seus próprios costumes aos alimentos disponíveis. A presença dos negros no contexto social familiar permitiu que as técnicas culinárias africanas, também, fossem incorporadas.

Não se pode tirar os méritos dos colonizadores. Eles conseguiram vencer bravamente as dificuldades. Mas algumas das conseqüências desta superação foram embriões de outras dificuldades que ainda estariam por vir.

Esse desenrolar de fatos mostra, aos mais atentos, a sedimentação lenta e contínua do que se pode chamar de "formação das bases da brasilidade alimentar". A presença de determinados alimentos, em detrimento de outros, cunhou um molde rígido no qual o sistema alimentar colonial, e mais tarde brasileiro, se conformou. 
Em outras palavras, pode-se entender porque o consumo de verduras (folhas) no nordeste é tão baixo. Não é apenas porque os nordestinos não gostam delas, mas porque não tiveram a oportunidade de aprender a comêla, diariamente, pela falta deste tipo de alimento ao longo de sua história. Um indivíduo, hoje, pode revelar que não tem ouvido falar de comer verduras em sua família desde seu tataravô.

Os atuais conhecimentos na área de Nutrição permitem, por outro lado, saber que a ausência crônica de um determinado tipo de alimento na dieta pode levar à ocorrência de determinadas doenças. Alguns exemplos mais imediatos seriam a possibilidade aumentada de anemias (ferropriva e megaloblástica) em uma população basicamente vegetariana, pela pouca carne disponível; ou ainda, dificuldades de formação e desenvolvimento corporal pela baixa ingestão de alimentos ricos proteínas, como leite ou ovos, etc., ou mesmo o reaparecimento do escorbuto, como já tem ocorrido em população das regiões árticas, que têm em sua dieta apenas carnes cruas de peixes e animais de caça, e nenhum vegetal, pois não crescem nestas regiões.

Dentre as enfermidades mais relatadas na colônia estão a varíola, febre amarela e sarampo (SILVA 1994). Todas são infecciosas e de natureza contagiosa. A grande disseminação e mortalidade por esses tipos de moléstias podem estar associadas à baixa imunidade da população. As causas para isso podem ser falta de contato anterior com a doença, o que não estimulou a produção prévia de anticorpos, ou, ainda, a pouca capacidade orgânica para lidar com infecções, dada a falta de nutrientes essenciais na dieta, que como se sabe, debilita os organismos. A falta de condições apropriadas de higiene e a prática sexual indiscriminada seguramente completariam o quadro.

Outras enfermidades, mas agora de caráter parasitário, também, surpreenderam e se disseminaram entre a população colonial. Desnecessário 
seria comentar que parasitas intestinais concorrem diretamente no aproveitamento dos alimentos ingeridos, debilitando seu portador, que, apesar de conseguir ingerir alimentos, não os aproveita como poderia. Isso fragilizaria, ainda mais, os indivíduos que não tivessem alimentos em quantidades suficientes.

Hábitos de higiene precários e praticados durante o período colonial ainda estão presentes em várias partes do país, especialmente, interior das regiões Norte e Nordeste e periferia das grandes cidades. Ocorre com isso a manutenção de procedimentos que comprometem a qualidade alimentar, prolongando o quadro de endemia de muitas doenças.

De fato, o que se quer mostrar é que as mesmas condições que permitiram a adaptação de colonizadores e escravos à colônia, são as que conferiram quadros endêmicos de subnutrição na população. Algumas das dificuldades enfrentadas durante o período colonial, ainda, estão presentes no Brasil de hoje, como já pode ser visto.

Não coube a este trabalho investigar e determinar as causas de tais determinantes, isso é tarefa para profissionais mais qualificados, mas apenas apresentar os fatos para que possam servir de suporte à compreensão de um dos fenômenos mais complexos e importantes da vida do homem, o seu hábito alimentar, e os elementos a ele relacionados.

A análise de toda essa situação não deve, contudo, gerar desânimo e pessimismo; ao contrário, as dificuldades devem ser enfrentadas e superadas com base em trabalhos sérios e que atendam a necessidade das populações, principalmente as mais carentes.

Olhando, também, para o lado positivo, pode se verificar que muitas dificuldades presentes por séculos de história estão sendo superados em muitas partes do mundo, pela introdução de alimentos, como a batata, o 
tomate e o cacau, que têm garantido as refeições diárias em muitos países, como já apresentado.

O avanço da gastronomia, que modernamente tem se voltado para os alimentos produzidos localmente, tem garantido a sustentação de cozinhas regionais ao redor do mundo; entre elas, as pioneira cozinhas baiana e mineira, além de outras, que têm surgido ao longo da história do Brasil.

Nem tudo é ruim nesta história. Como uma flor que brota no deserto, aproveitando as minúsculas partículas de água, que se condensam na madrugada sobre suas pétalas, fornecendo a importantíssima água, assim tem sido a história da alimentação neste país; onde tudo podia dar errado, algo floresceu.

Enfim, espera-se, com este trabalho, ter havido uma contribuição para que muitos profissionais olhem diferente para seus pacientes e clientes, sabendo que nenhum deles está solto no tempo e espaço, mas que fazem parte de um grande contexto histórico, político e social, que não deu a eles sua devida importância, negando-lhes, muitas vezes, por força das circunstâncias, a oportunidade de uma boa alimentação. 


\section{6 - REFERÊNCIAS}

Abramovay R. Fome e assalariados rurais. In: Minayo MCS, organizadora. Raízes da fome. Petrópolis: Editora Vozes; 1985.

Algranti LM. "Famílias e vida doméstica". In: In: Souza L de M. História da vida privada no Brasil: cotidiano e vida privada na América portuguesa. São Paulo: Ed. Shwarcz; 1998.

Alencar J. Iracema. São Paulo: Ed. Núcleo; 1993.

Arnaut SD. A arte de comer em Portugal na Idade Média. Lisboa: Imprensa Nacional Casa da Moeda; 1986.

[AHM] Atlas da História do Mundo. 4a ed. São Paulo: Ed. Geoffrey Parker; 1995.

Bathe BW, Cervin GBR, Taillemite E, Burgess RH, Collins RJ, Franzén A. The great age of sail. London: Edita Lausanne; 1967.

Barretto, SAJ, Cyrillo DC, Cozzolino SMF. Análise nutricional e complementação alimentar de cesta básica derivada do consumo. Rev Saúde Pública [artigo "on line"] 1998; 32 (1). Disponível em <URL http:/ / www.scielo.br/scielo.php?script=sci_home\&lng=pt\&nrm=isso> [2001 Jul 12].

Bertolini RF. Contribuição nutricional e educativa da refeição servidas aos participantes do projeto “Esporte/Talento, da USP e Instituo Ayrton Senna, no restaurante do campus central da USP. São Paulo; 1996. [Dissertação de Mestrado - Faculdade de Saúde Pública da USP]. 
Botting D. The pirates. Amsterdam: Time-Life Books; 1980.

Boxer CR. A mulher na expansão ultramarina ibérica. Lisboa: Livros Horizonte; 1977.

Brandão D. A cozinha baiana: origens, erudição, tradições populares e estudos. Rio de Janeiro: Ed. Tecnoprint; 1948.

Bueno E. A viagem do descobrimento. Rio de Janeiro: Ed. Objetiva; 1998. 1v.

Cainé V. A saúde e a doença na época dos descobrimentos. 2001. Disponível em <URL http://www.terravista.pt/IlhadoMel/1254/aberturaTT1.htm > [2001 Jul 02].

Canesqui AM. Antropologia e alimentação. Rev Saúde Pública. 1988; 22: 207-16.

Camões L de. Os lusíadas. São Paulo: Abril Cultural; 1979.

Campos R. História do Brasil. São Paulo: Editora Atual; 1983.

Cardim F. Tratados da terra e gente do Brasil. São Paulo: Ed. Universidade de São Paulo; 1980.

Castro J. A alimentação brasileira à luz da geografia humana. Rio de Janeiro: Ed. Globo; 1937.

Chaves N. Panorama nutricional do Brasil. In: Lacaz C da S, Baruzzi RG, Siqueira Júnior W. Introdução à geografia médica do Brasil. São Paulo: Edusp; 1972. 
Chonchol J. O modelo de industrialização dos países industrializados. In: Minayo MCS, organizadora. Raízes da fome. Petrópolis: Editora Vozes; 1985.

Clio História. Imagens ["on line"] 2001a. Internet Grátis. Disponível em <URL http:// www.cliohistoria.hpg.ig.com.br/index.htm > [2001 Nov 13].

Clio História. Rugendas. ["on line"] 2001a. Internet Grátis. Disponível em <URL http:// www.cliohistoria.hpg.ig.com.br/index.htm > [2001 Nov 13].

Cosman MP. Fabulous feasts. New York: G. Brazillier; 1976.

Cunha L. Testamento político de D. Luís da Cunha. São Paulo: Editora AlfaÔmega; 1976. 1v.

[DIEESE] Departamento Intersindical de Estatística e Estudos Socioeconômicos. Metodologia da pesquisa cesta básica Dieese \& Procon. São Paulo: 1994.

Durant W. História da civilização. São Paulo: Editora Nacional; 1943.

[EPO] Enciclopédia Portuguesa Online. Editorial Verbo, Lisboa, 1998. Disponível em: < URL: http://www.editorialverbo.pt/enciclopedia/ consulta.frame.html> [2001 Mai 22].

[EFUSP] Escola do Futuro da Universidade de São Paulo. Debret. ["on line"]. Biblioteca virtual do estudante. 1998. Disponível em < URL http://www. bibvirt.futuro.usp.br/acervo/audiovisual/visual/debret/debret_index.html [2001 Nov 12].

Ferlini VLA. Terra, trabalho e poder: o mundo dos engenhos no Nordeste colonial. São Paulo: Ed. Brasiliense; 1988. 
Fernandes F. Circuito Fechado: Quatro ensaios sobre o "poder institucional". São Paulo: Ed. Mucitec; 1976.

Ferreira GFA. História da saúde e dos serviços de saúde em Portugal. Lisboa: Fundação Calouste Gulbenkian; 1990.

Flandrin JL, Montanari M. História da alimentação. Trad. de LV Machado e GJF Teixeira. São Paulo: Ed. Estação Liberdade; 1998. Tempos modernos; p. 532 - 559 .

[FNB] Food and Nutriton Board. National Research Coucil. Recommended Dietary Allowances. $9^{\mathrm{a}} \mathrm{ed}$. Washington DC: National Academy of Sciences, 1980.

Franco A. Gastronomia: uma breve história ilustrada. Rio de Janeiro: Editora Guanabara; 1986.

Franco Júnior H, Andrade Filho RF. O império bizantino. $3^{a}$ ed. São Paulo: Ed. Brasiliense; 1989.

Freyre G. Casa-grande \& sanzala. 13a ed., Brasília: Ed. Universidade de Brasília; 1963.

Frieiro E. Feijão, angu e couve: ensaio sobre a comida dos mineiros. $2^{\mathrm{a}} \mathrm{ed}$. Belo Horizonte: Ed. da Universidade de São Paulo e Ed. Itatiaia; 1982.

Gil AC. Métodos e técnicas de pesquisa social. 4" ed. Sãc Paulo: Ed. Atlas; 1995.

Giordani MC. História do mundo árabe medieval. $3^{\mathrm{a}}$ ed. Petrópolis: Editora Vozes; 1985. 
Gomes Filho AG. Um tratado da cozinha portuguesa do século XV. $2^{\mathrm{a}}$ ed. Rio de Janeiro: Fundação Biblioteca Nacional; 1994.

Griswold RM. Estudo experimental dos alimentos. Trad. de AC Santos. São Paulo: Ed. Edgard Blücher; 1992.

[IBGE] Instituto Brasileiro de Geografia e Estatística Pesquisa de Orçamentos Familiares. [“on line”] 2001 Disponível em URL<http://www.sidra.ibge.gov.br> [2001 Out 25].

Krause M, Mahan L. Alimentos, nutrição e dietoterapia. 7a ed. São Paulo: Editora Roca; 1991.

Lacaz C da S. Os fatos essenciais da geografia humana; o homem em seus ambiente; população, tipos humanos; habitat e subdesenvolvimento; a assistência médica no Brasil; movimentos migratórios e doenças infecciosas e parasitárias; alimentação e endemias rurais. In: Lacaz C da S, Baruzzi RG, Siqueira Júnior W. Introdução à geografia médica do Brasil. São Paulo: Edusp; 1972.

Langley A. Medieval Life. London: Darling Kindersley; 1996.

Léry J de. Viagem à terra do Brasil. Belo Horizonte: Ed. Itatiaia e Edusp; 1980.

Lima VC. As dietas africanas no sistema alimentar brasileiro. In: Cardoso B, Bacelas J. Faces da tradição afro-brasileira. Salvador: Ed. Fallas, 1999a.

Lima VC. Etnocenologia e etnoculinária do acarajé. In: Greiner C, Bião A. Etnocenologia: textos selecionados. São Paulo: Ed. Anna Blenna; 1999b. 
Lima Z. Considerações sobre a culinária maranhense. São Luis: Edições SIOGE; 1977.

Linhares MY, Silva F. História da agricultura brasileira, combates e controvérsias. Rio de Janeiro: Ed. Brasiliense; 1981.

Lemps $\mathrm{AH}$ de. As bebidas coloniais e a rápida expansão do açucar. In: Flandrin JL, Montanari M. História da alimentação. Trad. LV Machado e GJF Teixeira. São Paulo: Ed. Estação Liberdade; 1998.

Lorena C. A questão agrária no Brasil. In: Minayo MCS, organizadora. Raízes da fome. Petrópolis: Editora Vozes; 1985.

Lowenberg ME, Todhunter EM, Wilson ED, Feeney MC, Savage JR. Los alimentos y el hombre. Cidade del Mexico: Editorial Limusa-Wiley; 1970.

Machado JM. Alimentos antigos e alimentos novos. Anais da Academia Portuguesa de História. 1984; 29: 505-528.

Marques $\mathrm{AH}$ de $\mathrm{O}$. A sociedade medieval portuguesa, aspectos da vida quotidiana. Lisboa: Sá da Costa; 1974.

Martins Fontes Editores. O livro da arte. Trad. de M Stahel. São Paulo, 1997.

Menezes J de V. Apoio sanitário na época dos descobrimentos. Lisboa: Ed. Academia da Marinha Portuguesa; 1987.

Mesgravis L, Pinsky, CB. O Brasil que os europeus encontraram. São Paulo: Ed. Contexto; 2000.

Minayo MCS, organizadora. Raízes da fome. Petrópolis: Editora Vozes; 1985. 
Minayo MCS, Cruz Neto O. Introdução. In: Minayo MCS, organizadora. Raízes da fome. Petrópolis: Editora Vozes; 1985.

Montanari M. Rumo a um novo equilíbrio alimentar. In: Flandrin JL, Montanari M. História da alimentação. Trad. LV Machado e GJF Teixeira. São Paulo: Ed. Estação Liberdade; 1998.

Moreno HB. A feitiçaria em Portugal no século XV. Anais da Academia Portuguesa de História. 1994; 29: 29-30.

Morse R. O espelho de próspero: cultura e idéias nas Américas. Trad. P Neves. São Paulo: Cia das Letras; 1995.

Mousnier R. História geral das civilizações: os séculos XVI e XVII Progressos na civilização européia. Trad. de V Ramos e J Guinsburg. São Paulo: Ed. Difusão Européia do Livro; 1957.

Mundo Antigo. Brasil colonial ["on line"]. 2001a. Disponível em <URL http://planeta.terra.com.br/arte/mundoantigo/colonial/entrada> [2001 Jun 281.

Mundo Antigo. Idade média ["on line"]. 2001b. Disponível em <URL http:/ / planeta.terra.com.br/arte/mundoantigo/idademedia> [2001 Jun 28].

Mundo Antigo. Mesopotâmia ["on line"]. 2001c. Disponível em <URL http://planeta.terra.com.br/arte/mundoantigo/egito > [2001 Jun 28].

Mundo Antigo. Os egípcios ["on line"]. 2001d. Disponível em <URL http://planeta.terra.com.br/arte/mundoantigo/mesopotâmia> [2001 Jun 28]. 
Nascimento EA do. A questão da terra no nordeste vista por um trabalhador rural. In: Minayo MCS, organizadora. Raízes da fome. Petrópolis: Editora Vozes; 1985.

Nóbrega M. Cartas do Brasil, 1549 - 1560. Belo Horizonte: Ed. Itatiaia e Edusp; 1988.

[NEB] Nova Enciclopédia Barsa. São Paulo: Encyclopedia Britannica do Brasil Publicações; 1997.

Novais FA. Condições da privacidade na colônia. In: Souza L de M. História da vida privada no Brasil: cotidiano e vida privada na América portuguesa. São Paulo: Ed. Shwarcz; 1998.

[NPILL] Núcleo de Pesquisas em Informática, Literatura e Lingüistica. A carta de Pero Vaz de Caminha. ["on line"] 2001. Universidade Federal de Santa Catarina. Disponível em <URL http://www.cce.ufsc.br/ nupill/ literatura/carta.html>[2001Jul09].

Olga's gallery. Frans Snyders. ["on line"] 2001. Disponível em <URL http://www.abcgallery.com/S/snyders/snyders.html 12.07.01> [2001 Jul 12].

Oliveira F. Apresentação à edição brasileira: Breve panorama medieval In: Loyn HR. Dicionário da Idade Média. Trad. de A Cabral. Rio de Janeiro: Editor Zahar Jorge; 1990.

Oliveira SP, Thébaud-Mony A. Estudo do consumo alimentar: em busca de uma abordagem multidisciplinar. Rev Saúde Pública. 1997; 31(2):201-8.

Ornellas LH. Técnica dietética. Rio de Janeiro: Ed. Letras e Artes; 1963. 
Ornellas LH. A alimentação através dos tempos. Rio de Janeiro: Série Cadernos Didáticos/FENAME; 1978.

Philippi ST. Hábitos alimentares. São Paulo; 1992 [Boletim técnico do Centro de estudos Silus - Alimentação e Serviços].

Polo M. O livro das maravilhas. Trad. de E Braga Júnior. Porto Alegre: Ed. Pallotti; 1994

Prado Jr. C. Formação do Brasil contemporâneo. $8^{\mathrm{a}}$ ed. São Paulo: Ed. Brasiliense, 1965.

Querino M. Costumes africanos no Brasil. 2a ed. Recife: Funart; 1988.

Ramos FP. Os problemas enfrentados no cotidiano das navegações portuguesas da carreira da Índia: fator de abandono gradual da rota das especiarias. Rev História. 1997; 137 (2): 75-94.

Riera-Melis A. Sociedade feudal e alimentação (séculos XII e XIII) In: Flandrin JL, Montanari M. História da alimentação. Trad. de LV Machado e GJF Teixeira. São Paulo: Ed. Estação Liberdade; 1998.

Robert JN. Os prazeres de Roma. Trad. de M Appenzeller. São Paulo: Ed. Martins Fontes; 1995.

Romani S de AM. Perfil alimentar e posse da terra na área rural do estado de Pernambuco, nordeste do Brasil. Rev Saúde Pública 1986; 20(5): 369-76.

Roque MC. A "peste grande" de 1569 em Lisboa. Anais da Academia Portuguesa de História. 1982; 28: 71-90. 
Rosengarten Jr F. The book of spices. New York: Piramid Communicatios Inc; 1973.

Sabbatini RME. A História das Vitaminas : Alimentos que Salvam. ["on line"] Núcleo de Informática Biomédica da UNICAMP. Campinas: UNICAMP; 1997. Disponível em <URL http://www.epub.org.br / nutriwob /n0201/ hipovitaminoses.htm > [2001 Jul 03].

Sachs I. A questão alimentar e ecodesenvolvimento. In: Minayo MCS, organizadora. Raízes da fome. Petrópolis: Editora Vozes; 1985.

Salvador V. História do Brasil 1500 - 1627. São Paulo: Edusp; 1982.

Samara E de M. Família e vida doméstica no Brasil: do engenho aos cafezais. São Paulo: Humanitas Publicações; 1999. (Estudos CEDHAL no 10).

Sampaio PA. Reforma agrária, produção e consumo de alimentos. In: Minayo MCS, organizadora. Raízes da fome. Petrópolis: Editora Vozes; 1985.

Schwartz S. Segredos internos: engenhos e escravos na sociedade colonial. São Paulo: Cia das Letras; 1988.

[SPP] Secretaria de Políticas de Saúde. Ministério da Saúde. Política Nacional de Alimentação e Nutrição do Setor Saúde. Rev. Saúde Pública [artigo “on line"]. 2000; 34 (1). Disponível em <URL http://www.scielo.br/scielo.php?

script $=$ sci_home\&lng=pt\&nrm $=$ iso $>[2001 \mathrm{Jul} 12]$.

Seguier J. Dicionário prático ilustrado: novo diccionário encyclopedico luso-brasileiro. $3^{\text {a }}$ ed. Porto: Livraria Chardon; 1931. 
Silva MBN da, coordenadora. Dicionário da história da colonização portuguesa no Brasil. Lisboa/São Paulo: Ed. Verbo; 1994.

Simopoulos AP. Nutrition and fitness from the first Olympiad in $776 \mathrm{BC}$ to 393 AD and the concept of positive health. Am J Clin Nutr 1989; 49: 921-6.

Singer P. Os efeitos da crise econômica sobre o estado de nutrição dos brasileiro. In: Minayo MCS, organizadora. Raizes da fome. Petrópolis: Editora Vozes; 1985.

Sousa GS. Tratado descritivo do Brasil em 1587. São Paulo: Cia Editora Nacional e Edusp; 1971.

Staden H. Duas viagens ao Brasil. Belo Horizonte: Ed. Itatiaia e Edusp; 1974.

Tavares MJF. História de Portugal medievo. Lisboa: Universidade Aberta; 1992.

Terra Networks. 500 anos do descobrimento ["on line]. 2000. Disponível em <URL www.terra.com.br/500anos> [2001 Jun 07].

Zurara GE. Crônica da guiné. Paris: Ed. Livraria Civilização; 1937. 


\section{1 - BIBLIOGRAFIAS CONSULTADAS}

Cuenca AMB. Guia de apresentação de teses. São Paulo: Faculdade de Saúde Pública; 1998.

Lakatos EM, Marconi, M de A. Metodologia do trabalho científico. $4^{\mathrm{a}}$ ed. São Paulo: Editora Atlas; 1992.

Severino AJ, Metodologia do trabalho científico. $19^{\star}$ ed. São Paulo: Ed. Cortez; 1993. 


\section{GLOSSÁRIO}

AFRESCO, um tipo de pintura.

ARRÁTEL, antiga unidade de peso, de 16 onças, correspondente a $459 \mathrm{~g}$.

ARROBA, peso equivalente a $15 \mathrm{~kg}$; peso antigo de trinta e dois arráteis.

AXORCA, argola usada como adorno das pernas ou dos braços.

AZEVIA, espécie de linguado, peixe;

BALEOTE, baleia nova; o filho da baleia.

BERÇA, couve.

BOTICA, farmácia.

BRAUDEL (FERNAND), Historiador francês (Luméville-en-Ornois, 1902Cluses, Haute-Savoie, 1985). Especialista em História Económica (Civilisation Matérielle, économie et Capitalisme, XV-XVIII, 1979), abriu à história o estudo dos fenómenos de longa duraçāo em La Méditerranée et le Monde Mediterranéen à l'époque de Philippe II (1949).

CALHANDRA, variedade de cotovia. Nome comum a diversas aves da família Alaudidac. A Alauda aroensis também se chama "calandra», "cotovia» e "laverca". A Melanochorypha calandra é mais conhecida em Portugal por «cotovia-real»e «cochicho».

CANTADEIRA, nome de ave palmípede da família dos Anáfidas, também, chamada marreca e rangedeira; cotovia .

CERCETA, cantadeira e marrequinho (aves palmípedes). 
DEBRET (JEAN-BAPTISTE) ${ }^{1}$ (1768-1848), pintor francês que esteve no Brasil com a Missão Artística Francesa. Nasceu em Paris a 18 de abril de 1768 e faleceu, na mesma cidade, a 11 de junho de 1848. Iniciou sua vida profissional em Paris, sob a influência de Jacques-Louis David. Integrando a Missào chefiada por Lebreton. Ficou no Brasil entre 1816 e 1831, dedicandose à pintura e ao magistério artístico. Em suas telas retratou não apenas a paisagem, mas sobretudo a sociedade brasileira, nào esquecendo de destacar a forte presença dos escravos. Foi iniciativa sua a realizaçào da primeira exposiçào de arte no país, em 1829.

Foi, dentre todos os artistas franceses, aquele que melhores e mais assinalados serviços prestou ao ensino da pintura, não só pelo grau de operosidade de que era dotado, como, ainda, porque tendo sabido vencer os obstáculos por que passara e calcar os dissabores que sofrera, the foi dado aqui permanecer mais tempo que qualquer outro, e formar discípulos continuadores de sua obra.

Quando D. Pedro subiu ao governo como regente, Debret lhe pedira, no que foi atendido, que lhe concedesse um dos ateliês do edifício da academia, para nele executar uma grande tela, que representasse a solenidade da coroaçào imperial. Aí reuniu o mestre os seus primeiros discípulos, aos quais lecionou pintura. Seu resultado com os alunos foi tão bom que em 1826, três anos depois da abertura da escola, D. Pedro resolve instalar a Academia.

Comemorando a inauguraçào dos cursos, Debret realizou a primeira exposiçào dos trabalhos dos seus discípulos. Foi grande o sucesso da exposiçào, tendo sido o seu organizador, e principal autor, condecorado com o oficiala to da Ordem de Cristo.

\footnotetext{
1 Informaçōes obtidas no site

http://www.pitoresco.com/pitoresco/brasil/debret/debret.htm.
} 
"Em meados de 1831, sentindo-se cansado de tantas lutas, adoentado e enfraquecido, farto de pelejar... e cônscio de que prestara ao Brasil os mais relevantes serviços pelo apostolado artístico exercido no Rio de Janeiro durante quinze anos, regressou à pátria." ("A Missāo Artística de 1916, A. Taunay).

Além de pintor notável, era dotado de um espírito altamente cultivado. Durante sua permanência aqui, colheu material para uma obra sobre o Brasil, obra cuja publicaçào iniciou em 1834, dando a lume o primeiro volume, sob o título: Voyage pitoresque et historique an Brésil, on Séjour d'un artiste français ao Brésil (Viagem pitoresca e histórica ao Brasil, on Cotidiano de um artista francês no Brasil). O segundo volume, publicou-o no ano seguinte e o terceiro, em 1839.

DIACIDRÃO, casca de cidra em doce.

DIÁSTASE, enzima que transforma o amido em glicose.

ESCORBUTO, doença atribuída à carência de vitamina $C$ e que se caracteriza pela tendência a hemorragias nas gengivas.

ESPECIARIAS, condimentos vegetais, quase todos de origem oriental, utilizados para dar sabor e aroma a algumas iguarias. Tais sảo, por exemplo, a canela, a noz-moscada, o gengibre, a pimenta, a mostarda, o açafrào, etc. Na Idade Média, eram produtos muito apreciados, tanto para a culinária como a farmacopéia. Vindos do Oriente, os turcos e muçulmanos auferiam elevados proventos com o tráfico das especiarias. A isso pôs termo a descoberta do caminho marítimo para a Índia por Vasco da Gama, em 1498. Deste modo, a partir do séc. XVI, o eixo do comércio mundial passou do Mediterrâneo para o Atlântico.

FORTALEZA, local onde se armazenavam os alimentos e outros gêneros para manutençào dos territórios conquistados pelas forças portuguesas. 
FUSELO, chalreta ou perna-vermelha (aves pernaltas). (De fuso + elo.). Pernaltas, antiga ordem de aves. A sua característica principal consiste em as patas serem alongadas e freqüentemente desnudadas, providas de dois ou três dedos virados para a frente e um só para trás. Vivem à borda da água, alimentando-se de peixes, moluscos e insetos. Possuem pescoço comprido e longo bico pontiagudo, como a cegonha, a garça e a galinhola.

GIGA, selha larga e de pouca altura; canastra em forma de selha (selha é um vaso redondo de madeira, com bordos baixos).

HIERÓGLIFO, cada um dos caracteres da escrita dos antigos egípcios.

LEPRA, doença infecciosa crônica provocada pelo bacilo de Hansen. Há 4 variedades de lepra: a lepromatosa (com lesōes cutâneas e evoluçào progressiva; é contagiosa), a tuberculóide ou nervosa (atinge os nervos periféricos; nào é contagiosa), a indeterminada (manchas rosadas; fase inicial da lepra) e a intermediária (em regra, contagiosa). Conhecida desde a Antigüidade, do Médio Oriente espalhou-se pela Europa, de onde praticamente desapareceu em nossos dias. Persiste no resto do Mundo. Atualmente consegue-se curar a lepra se o diagnóstico é feito precocemente.

MARAVEDI, antiga moeda gótica que teve curso em Portugal e Espanha.

MILHETE, variedade de milho, de grão muito miúdo.

PAIOL, lugar próprio, dentro das fortalezas ou dos navios, para armazenar os mantimentos.

PAPA-FIGO, pássaro (Oriulıs galbula, Lin.) do grupo dos Dentirrostros.

PARRILHA, espécie de saragoça ordinária. (saragoça, mandriào, ave; moleiro). 
PESTE, doença infecciosa aguda, altamente contagiosa. É causada por um micróbio (descoberto em 1894) parasita do rato e outros roedores: através da pulga é contaminado o homem. Extremamente letal, a peste (chamada peste negra por ser de tipo hemorrágico) de 1349 a 1351 eliminou $1 / 4$ da populaçào européia. Em medicina conhecem-se várias formas de peste, como a peste bubônica (gânglios na virilha ou bubào), a peste septicêmica (de febre elevadíssima sem repercussão ganglionar) e a peste pulmonar (aspecto de pneumonia aguda fulminante).

PIPA, grande vasilha bojuda de madeira para vinho e outros líquidos.

QUINTAL, peso antigo, correspondente a quatro arrobas, ou $60 \mathrm{~kg}$.

RABELAIS (FRANÇOIS), Escritor francês (1494-1553). Sacerdote franciscano (1521) passou para os Beneditinos em 1524 e acabou por abandonar a vida religiosa em 1535. Dedicou-se ao exercício da medicina e às letras, levando vida errabunda. Nos dois últimos anos de vida foi prior de Meudon. Criou dois personagens imortais, Gargântua e Pantagruel, heróis de uma história grotesca de gigantes. Epicurista em moral e naturalista no seu ajuizar dos homens e das instituiçòes, escreveu num estilo picaresco, de exuberante riqueza vocabular.

REFRESCO, auxílio; reforço; fornecimento de víveres.

RUGENDAS (JOHANN MORITZ)², Nascido em Augsburg, Rugendas foi filho de uma família de pintores da Alemanha corporativista dos séculos passados. Por influência de seu pai começou sua carreira na Academia. Desde essa época sentiu-se atraído por motivos animalistas, sobretudo pelo cavalo, tendo feito vários desenhos com incrivel perfeição anatômica, habilidade e vigor, qualidades que, inconfundivelmente, marcarào toda a

\footnotetext{
? Informaçòes obtidas no site http://www.cliohistoria.hpg.ig.com.br/inder htm
} 
sua produção artística. Já em Munique, por intermédio de Augusto Riedel, seu amigo intimo, Rugendas teve notícias de que o Cônsul russo Langsdorff preparava uma expediçào científica ao Brasil e que o botânico berlinense, Ludwig Riedel, dela participaria. Langsdorff era cientista de renome da Universidade de Gotinga. Ele, desde 1813, desempenhava o cargo de cônsul geral a serviço do czar da Rússia no Rio de Janeiro. Em sua fazenda Mandioca ao norte do Rio de Janeiro reunia plantas, animais e minerais constituindo um "arquivo" vivo da fauna e flora. Os naturalistas Spix e Martius, entre outros, haviam sido hóspedes na fazenda de Langsdorff e, provavelmente, haviam recomendado Rugendas. Fascinado em conhecer e retratar o Novo Mundo, assinou contrato com Langsdorff integrando a expediçào como desenhista. Chegou ao Brasil, com apenas 19 anos, em Março de 1822, hospedando-se na casa do Barào Wenzel von Mareschal, aqui ficando até 1825. Voltou ao Brasil de novo em 1830.

Rugendas procurou desenvolver estudos sobre a fauna e flora, adaptando-se ao mundo tropical. Durante suas viagens pelo Rio de Janeiro desenhava cenas que caracterizavam o cotidiano da cidade. Seus trabalhos se inserem claramente dentro de uma iconografia abolicionista sendo provável que Rugendas combinasse a sua própria experiência visual com as imagens difundidas pela Society for the Abolition of the Slave Trade. Quanto ao seu paisagismo Rugendas destacava vistas da baia de Guanabara e a silhueta das montanhas. A exuberância da floresta tropical só aparece como tela de fundo de cenas cotidianas.

Rugendas viu o Brasil para muito além de suas flora e fauna "exóticas". Acompanhou toda a efervescência política, já que, em Setembro de 1822, assistiu à independência do Brasil e a coroaçào de D. Pedro I. 
"As florestas nativas constituem a parte mais interessante das paisagens do Brasil", costumava dizer. Só dois anos mais tarde o pintor iniciou com Langsdorff a viagem científica pelas províncias de Minas Gerais, Sào Paulo, Goiás e Mato Grosso, visitando primeiramente a província de Minas. Em Ouro Preto nào foi a arquitetura barroca que impressionou o jovem alemào, todo voltado do estilo neoclássico, e sim a atividade aurífera. Ainda em Ouro Preto, ele se encontra com índios Monoxós e Maxakalis, que o conduz até suas aldeias, onde pode pintá-los em plena atividade.

Apaixonado pela capital brasileira, Rugendas escreveu: "É o mais belo porto da terra, situado num país que produz tudo que as necessidades físicas do homem exigem, tudo o que o Estado pode precisar da natureza para sua prosperidade... Uma cidade imperial, populosa, animada pela atividade do comércio mundial, imponente pelo esplendor que the emprestam as cerimônias do culto católico e os seus edifícios, e revelando na sua corte todo o brilho das cortes da Europa".

SALMOURA, porçào de água saturada de sal marinho, para conservar carnes ou outras substâncias orgânicas; vasilha em que se conservam essas substâncias, com a respectiva água salgada; água salgada em que se conservam azeitonas, umidade que escorre do peixe ou carne salgada.

SÍNODO, assembléia regular de párocos convocada por um bispo local.

TITELA, a parte carnuda do peito da ave; a parte mais apreciada de qualquer coisa.

TONEL, grande vasilha de aduelas, para líquidos, e cuja capacidade é igual ou superior à de duas pipas. 